UNIVERSIDADE DE SÃO PAULO

FACULDADE DE ECONOMIA, ADMINISTRAÇÃO E CONTABILIDADE DEPARTAMENTO DE ADMINISTRAÇÃO

PROGRAMA DE MESTRADO PROFISSIONAL EM EMPREENDEDORISMO

A APLICAÇÃO DO MARKETING DE RELACIONAMENTO EM PROVEDORES DE SOFTWARE AS A SERVICE (SAaS) B2B PARA MINIMIZAR TAXAS DE CHURN

Maria Gabriela F. de Noronha Orientador: Prof. Dr. Edson Crescitelli

São Paulo 
Prof. Dr. Vahan Agopyan

Reitor da Universidade de São Paulo

Prof. Dr. Fábio Frezatti

Diretor da Faculdade de Economia, Administração e Contabilidade

Prof. Dr. Moacir de Miranda Oliveira Junior

Chefe do Departamento de Administração

Prof. Dr. Marcelo Caldeira Pedroso

Coordenador do Programa de Mestrado Profissional em Empreendedorismo 
MARIA GABRIELA F. DE NORONHA

\title{
A APLICAÇÃO DO MARKETING DE RELACIONAMENTO EM PROVEDORES DE SOFTWARE AS A SERVICE (SAaS) B2B PARA MINIMIZAR TAXAS DE CHURN
}

\begin{abstract}
Dissertação apresentada ao Programa de Mestrado Profissional em Empreendedorismo do Departamento de Administração da Faculdade de Economia, Administração e Contabilidade da Universidade de São Paulo como requisito parcial para obtenção do título de Mestre em Ciências.
\end{abstract}

Orientador: Prof. Dr. Edson Crescitelli

Versão Corrigida

São Paulo

2020 


\title{
FICHA CATALOGRÁFICA
}

\author{
Catalogação na Publicação (CIP)
}

Ficha Catalográfica com dados inseridos pelo autor

Noronha, Gabriela .

A APLICAÇÃO DO MARKETING DE RELACIONAMENTO EM

PROVEDORES DE SOFTWARE AS A SERVICE (SaaS) B2B PARA

MINIMIZAR TAXAS DE CHURN / Gabriela Noronha . - São Paulo, 2020. $106 \mathrm{p}$.

Dissertação (Mestrado) - Universidade de São Paulo, 2020.

Orientador: Edson Crescitelli.

1. Marketing de relacionamento . 2. SaaS. 3. Churn . 4. Estudo de Caso . I. Universidade de São Paulo. Faculdade de Economia, Administração e Contabilidade. II. Título. 
À minha amada mãe, Isabel Noronha. 


\section{Agradecimentos}

A Deus, por se fazer sempre presente em minha vida e me permitir realizar mais um dos meus desejos.

A meu orientador, Prof. Dr. Edson Crescitelli, que esteve sempre disponível para me escutar e me orientar, abrindo caminhos para a pesquisa e me ajudando a descobrir a Gabriela pesquisadora. Obrigada por todos os conselhos e por fazer parte dessa jornada de maneira tão presente, Professor.

Ao Prof. Dr. Antonio Carlos Sauaia, por ministrar com tanto amor e zelo a melhor disciplina do Mestrado por mim cursada: Laboratório de Gestão. Como eu aprendi com o senhor, Prof. Sauaia. Obrigada por ministrar cada aula com tanta paixão pela academia, como se fôssemos sua primeira turma. Seu entusiasmo é contagiante e inspirador.

Aos demais professores da FEA USP. Aos funcionários da biblioteca, da secretaria e, em especial, à Fabi, Fabiana Caseiro, por estar sempre tão disponível a me ajudar sempre que precisei.

A todos os entrevistados que fizeram parte da pesquisa de campo, pela disponibilidade, receptividade e compartilhamento de conhecimento.

Em especial, à minha mãe, Isabel, já que sem ela essa conquista não seria possível. Foi ela que cuidou da minha filha, ainda bebê, para que eu pudesse comparecer às aulas e escrever a dissertação durante dois anos e meio. Gostaria de agradecer também aos meus irmãos, Professores Doutores da UFMG e UFRJ, pelo exemplo que me deram e ainda me dão todos os dias. Meu irmão, Thiago, foi um grande incentivador para que eu adicionasse não só o conhecimento prático, mas também científico ao meu currículo.

Finalmente, ao meu marido, Mahmoud, e à minha filha, Mariam, pela compreensão diante de todos os momentos em que estive ausente. Essa conquista é nossa. 


\section{Resumo}

A habilidade de uma empresa em criar e manter um relacionamento duradouro com seus clientes no contexto business-to-business (B2B) é considerada vital para obter boa performance. Para muitas empresas, contudo, já não basta apenas adquirir clientes para manter-se lucrativas, é preciso também desenvolver ações para fidelizá-los, assim como defende o marketing de relacionamento, citado pela primeira vez na literatura do marketing na década de 1980. Empresas provedoras de SaaS (Software as a Service), modelo de comercialização de software entregue pela internet e não mais instalado na máquina do cliente, são um bom exemplo de negócio que enfrenta desafios no relacionamento com clientes $B 2 B$. Apesar de possuírem acesso a vários recursos tecnológicos, essas empresas enfrentam um problema de retenção de clientes, representado pelas altas taxas de cancelamento de contrato (churn). O objetivo desta pesquisa é identificar como provedores de SaaS B2B podem aplicar ações de marketing de relacionamento para minimizar suas taxas de churn e quais dessas ações seriam as mais eficazes para fidelizar clientes. Tanto as análises feitas ainda no referencial teórico, quanto às descobertas do estudo de caso concluíram que ações de marketing de relacionamento - em especial, aquele voltado à satisfação, qualidade, comprometimento, comunicação e personalização -, são essenciais no combate ao churn em empresas de $S a a S$ e devem fazer parte não somente do atendimento individualizado a clientes de grande porte, como também do atendimento em escala aos pequenos clientes. $\mathrm{O}$ onboarding, primeiro contato do cliente com seu gerente de relacionamento, é o momento-chave para desenvolver ações de marketing de relacionamento em escala.

Palavras-chave: Marketing de relacionamento; B2B; Software as a Service; churn. 


\begin{abstract}
A company's ability to create and maintain a long-lasting relationship with its customers in the B2B (Business-to-Business) context is considered vital to obtain a good performance. For many companies, it is not enough to just acquire customers to remain profitable, it is also necessary to develop actions to retain them, as mentioned by the relationship marketing theory, cited for the first time in the literature in the 1980s. SaaS companies (Software as a Service), a software delivery model provided through the internet, and no longer installed on the customer's computer, is a good example of a business that faces challenges in B2B relationships. Despite having access to various technological resources, these companies face a customer retention problem represented by the high rates of contract cancellation (churn). The purpose of this research is to identify how B2B SaaS providers can apply relationship marketing actions to reduce their churn rates and which actions would be considered the most useful to achieve this goal. The theoretical analysis conducted, together with the case study, concluded that relationship marketing actions; in particular satisfaction, quality, commitment, communication and personalization are essential in fighting churn in SaaS companies; and they must be part of not only individualized service to large customers, but also to scale services to small customers. The onboarding, customer's first contact with it's relationship manager, is the key moment to perform relationship marketing actions at scale.
\end{abstract}

Keywords: Relationship marketing; B2B; Software as a Service; churn. 


\section{Sumário}

1 Introdução 12

2 Fundamentação teórica $\quad 17$

$\begin{array}{ll}\text { 2.1 Marketing de relacionamento } & 17\end{array}$

2.1.1 Relacionamento B2B 21

2.1.2 Elementos do marketing de relacionamento 22

2.1.2.1 Satisfação 22

2.1.2.2 Qualidade 25

2.1.2.3 Confiança 28

2.1.2.4 Comprometimento $\quad 29$

2.1.2.5 Comunicação constante e personalização 31

2.1.3 Churn 33

2.2 Software as a Service (SaaS) $\quad 35$

2.2.1 Relacionamento High Touch x Low Touch 38

2.2.2 Causadores de Churn em empresas de SaaS 39

2.2.3 O marketing de relacionamento na prevenção do churn em SaaS 47

2.3 Considerações sobre a revisão teórica $\quad 54$

3 Pesquisa Empírica $\quad 58$

3.1 Classificação da Pesquisa $\quad 58$

3.2 A Escolha do Caso $\quad 61$

3.3 Introdução ao estudo de caso $\quad 62$

3.4 Introdução às entrevistas $\quad 66$

3.6 Entrevistas com executivos high touch $\quad 70$

$\begin{array}{ll}3.7 \text { Entrevistas com executivos low touch } & 80\end{array}$

3.8 Entrevista com a líder do projeto Low Touch 90

4 Análise do estudo de caso $\quad 93$

5 Considerações finais $\quad 102$

$\begin{array}{ll}\text { Referências } & 105\end{array}$

$\begin{array}{ll}\text { Anexos } & 106\end{array}$ 


\section{Lista de Tabelas}

Tabela 1 - Previsão do crescimento do setor de SaaS (milhões de dólares). .35

Tabela 2 - A aplicação do marketing de relacionamento para prevenção do churn.52

Tabela 3 - Identificando o método de pesquisa..............................56

Tabela 4 - Esquema de entrevistas.....................................62

Tabela 5 - O marketing de relacionamento nos modelos high touch e low touch....90

Tabela 6 - O novo Low Touch e o marketing de relacionamento....................96 


\section{Lista de Figuras}

Figura 1 - Qualidade como fonte inicial de geração de lucro......................25

Figura 2 - Modelo de Henning-Thurau e Klee................................28

Figura 3 - Comunicação como fator de fidelização de clientes.....................31

Figura 4 - Responsáveis por garantir a boa experiência do cliente....................39

Figura 5 - Onde acontece o processo de onboarding ...........................42

Figura 6 - O início do projeto Low Touch ...................................60

Figura 7 - Estrutura para análise de dados.................................64

Figura 8 - Exemplo de informações de um $Q B R(1) \ldots \ldots \ldots \ldots \ldots \ldots \ldots \ldots \ldots \ldots \ldots \ldots$

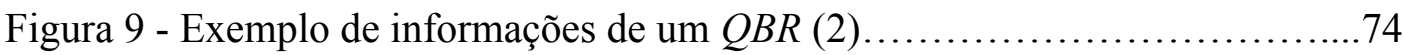

Figura 10 - O comportamento das primeiras contas low touch .....................76

Figura 11 - Aprendizados do projeto Low Touch e o marketing de

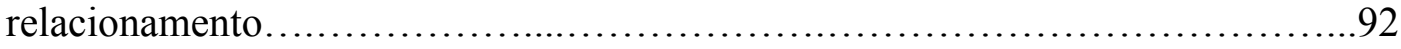

Figura 12 - Modelos de onboarding.........................................99 


\section{Introdução}

Nas últimas décadas, tem sido percebida uma tendência no contexto empresarial business-to-business (B2B) em estabelecer relações cada vez mais próximas entre vendedores e compradores (Ulaga \& Eggert, 2006). De acordo com Leonidou (2004), essa prática ajuda a criar valor e é considerada benéfica para as duas partes. Além disso, é vista como uma iniciativa vantajosa, porque é difícil de ser entendida por competidores, copiada ou transferida. (Day, 1997) O mercado global também enxerga essa habilidade como um diferencial. De acordo com Palmatier e Steinhoff (2019), os investidores mudaram seus critérios e estão adquirindo empresas que tenham forte relacionamento com clientes e não somente fortes marcas.

Corporações de todos os setores, ao reconhecerem o relacionamento como sendo algo inerente ao ser humano, começaram a construir suas estratégias de marketing a partir de fundamentos como as interações cada vez mais estreitas com sua base de clientes (Palmatier \& Steinhoff, 2019). Curiosamente, de acordo com Berry (1995), essa preocupação em elaborar estratégias de marketing levando em consideração clientes existentes, denominada por ele marketing de relacionamento, não apareceu até a década de 1980 e não foi um tema de interesse de pesquisadores de marketing ou de empresas da época.

Berry (1983, p.25) definiu o termo pela primeira vez como: “[...] estratégias para atrair, manter e, em empresas de multisserviço, melhorar o relacionamento com o cliente". Nessa mesma publicação, Berry insistia que a aquisição de novos clientes deveria ser vista apenas como um passo intermediário no processo de marketing. De acordo com Gronroos et al. (1994, p.2), também estudioso do marketing de relacionamento: “[...] marketing é estabelecer, manter e melhorar relações com clientes e parceiros para que, em uma troca de promessas bilaterais, os objetivos das duas partes sejam atingidos”.

Em sua pesquisa mais recente sobre o tema, Palmatier e Steinhoff (2019) comentam que a teoria do marketing de relacionamento está longe de ter atingido um estágio maduro; neste 
momento, está em um estágio de ressurgimento frente a todas as mudanças ocasionadas pelo acesso à tecnologia. De acordo com os autores, a era digital provocou uma mudança nas interações sociais de humano-para-humano para interações impessoais, digitais e eletrônicas mediadas pela tecnologia. Com interações cada vez mais impessoais, nas quais o contato presencial de pessoa para pessoa já não prevalece, manter relações estreitas, próximas e duradouras se torna um desafio.

Nesse contexto, provedores de SaaS (software como serviço ou software as a service) são exemplos de empresas que estão buscando a melhor maneira de se relacionar com seus clientes no cenário $B 2 B$, principalmente com o objetivo de retê-los para se manter lucrativas. O SaaS é um modelo de entrega de software através da nuvem (internet), diferente do modelo tradicional, em que o produto era instalado na máquina do cliente. Apesar de todo o sucesso alcançado no mercado em nível global, provedores de SaaS estão constantemente lidando com o churn, cancelamento de contrato por parte de seus clientes, o que tem se tornado seu principal desafio (Najjar et al., 2017; Yizhe et al., 2017).

É consenso que o churn sempre irá acontecer no modelo de venda de SaaS (Rautio, 2019) e nenhuma empresa está imune a ele, seja porque o cliente não tem mais dinheiro para pagar, está sofrendo uma crise ou entrou em falência (Murphy, 2017). O real problema enfrentado por essas empresas é que, se elas apresentam altas taxas de churn e perdem clientes em uma velocidade maior do que ganham novos clientes e/ou aumentam os contratos com clientes existentes (upsell/crossell), não conseguem se manter lucrativas (Skok, 2016). O relacionamento com o cliente no contexto $B 2 B$ passa a ser cada vez mais importante para o sucesso dessas empresas.

O SaaS continua sendo o maior segmento do mercado de computação na nuvem, com um crescimento de receita esperado de 17,5\%, chegando a 110 bilhões de dólares em 2020 . Estima-se que o setor fature cerca de 147 bilhões de dólares em 2022, mais que o dobro do arrecadado em 2018 (Gartner, 2019). Apesar do sucesso, de acordo com o novo relatório da KeyBanc Capital Markets (2018), que entrevistou 385 empresas privadas de $S a a S$ ao redor do mundo, a taxa de churn (cancelamento de contratos) anual dessas empresas gira em torno de 
13.2\%. A cada ano, depois dos gastos expressivos com marketing para adquirir clientes, uma parte considerável deles deixa de assinar o serviço. De acordo com um estudo feito com 1.000 startups de SaaS no mundo (Law, 2019), 5 a 7\% seria a taxa de churn ideal para uma empresa de SaaS madura.

Existe, ainda, um agravante no modelo de negócio $S a a S$ que contribui com suas altas taxas de cancelamento de contrato. Por fazer parte de um modelo de negócio de receita recorrente pago por assinatura (geralmente mensal ou anual), se o provedor de $S a a S$ não cumpre com as expectativas da empresa compradora, ela pode rapidamente cancelar o serviço, e o provedor vai perder todo o dinheiro investido em tornar aquela empresa cliente. Se estão satisfeitos com o serviço, os clientes vão permanecer assinando e pagando por ele; por outro lado, clientes insatisfeitos respondem rapidamente com o churn (Skok, 2016).

Como a aquisição dos clientes nesse setor é muito cara, a retenção deles é essencial, já que, só depois de doze meses em média, o investimento inicial para adquirir o cliente é reconquistado (Yizhe et al., 2107). De maneira resumida, a aquisição de clientes é importante no setor de SaaS, mas não menos que sua retenção (Le, 2019). Para reter clientes no contexto $B 2 B$, mais do que nunca, é preciso saber relacionar-se com eles.

Isso faz com que o modelo de negócio do software como serviço (SaaS) apresente uma dinâmica totalmente diferente da dinâmica do software tradicional. Nele, duas vendas precisam ser feitas: adquirir o cliente e mantê-lo, maximizando seu potencial de compra ao longo do tempo (Skok, 2016). Fica claro que empresas que seguem esse modelo de negócio precisam, apesar da distância, se manter próximas de seus clientes e torná-los leais, o que, de maneira direta, propõe a teoria do marketing de relacionamento, desde a primeira vez em que foi citada por Berry (1983).

A partir do contexto apresentado, esta pesquisa visa elucidar a seguinte pergunta:

\section{Como provedores de $S a a S B 2 B$ podem aplicar ações de marketing de relacionamento para minimizar suas taxas de churn?}


Levando em consideração a questão acima, o seguinte objetivo foi estabelecido para esta pesquisa:

Identificar quais ações do marketing de relacionamento podem auxiliar empresas de SaaS B2B a minimizar taxas de churn.

O estudo envolverá uma revisão teórica e será complementado por uma pesquisa empírica na forma de estudo de caso. O referencial teórico da pesquisa será dividido em três seções, a saber: marketing de relacionamento, software as a service (SaaS) e, por último, um fechamento com considerações finais. O estudo de caso será feito em uma empresa provedora de $S a a S$ americana com subsidiária brasileira. A empresa, denominada na pesquisa de " $A B C$ Software”, fornece software aplicativo B2B para seus clientes tanto no Brasil como em outros países da América Latina. A empresa foi escolhida como objeto de estudo porque passou recentemente por uma reestruturação no modelo de relacionamento com o cliente, com o objetivo de reduzir suas taxas de churn.

É importante deixar claro que este estudo não tem como foco estudar aplicativos de software que ajudam empresas na gestão do relacionamento com seus clientes, como os CRMs (customer relationship management ou gestão de relacionamento com o cliente). O SaaS é um modelo de entrega de software por meio da nuvem/internet com pagamento feito por assinatura; e o $C R M$ é, na verdade, um aplicativo de software entregue através do modelo SaaS. Sobre isso, o Blog da Microsoft Azure (2019) exemplifica: “[...] para uso organizacional, você pode assinar aplicativos de produtividade como o CRM (gerenciamento de relacionamento com o cliente), ou ERP (planejamento de recursos empresariais). Você paga pelo uso desses aplicativos por assinatura, já que eles seguem o modelo $S a a S$ de entrega de software".

Resumindo, o CRM é um software que facilita as ações de marketing de relacionamento, já que possibilita armazenar informações do cliente, como, por exemplo, suas preferências, histórico de compras, onde ele mora, ou qualquer informação que ajude o time de vendas a 
interagir melhor com ele. De acordo com Tanuri (2016), o marketing de relacionamento age na estratégia, enquanto o $C R M$ é uma ferramenta, um software, que ajuda empresas a implementar essa estratégia. 


\section{Fundamentação teórica}

Este estudo se organiza em três blocos: no primeiro, será introduzida a teoria do marketing de relacionamento, sua inserção no contexto $B 2 B$, bem como os elementos que fazem parte das ações propostas pelo marketing de relacionamento. No segundo, será apresentado o modelo SaaS de entrega de software, as características do modelo e tipos de relacionamento com clientes encontrados no setor, além das principais causas de churn em empresas de SaaS. No terceiro e último bloco, será feita uma análise que correlaciona o marketing de relacionamento e o setor de SaaS, identificando quais ações do marketing de relacionamento poderiam ser úteis para a diminuição das taxas de churn no setor.

\subsection{Marketing de relacionamento}

Em 1983, pela primeira vez na literatura do marketing, foi mencionado, em um artigo científico, o termo relationship marketing ou marketing de relacionamento. Para Berry (1983), solidificar as relações e transformar clientes indiferentes em leais deveria também ser um fator considerado como parte das funções do marketing. Em um artigo posterior, em 1995, Berry comenta que, até a década de 1980 , o foco do marketing estava apenas em adquirir novos clientes e não em garantir a lealdade de clientes existentes.

Para Gordon (1998), marketing de relacionamento é um processo contínuo de criação de valor e compartilhamento de benefício entre empresa e cliente durante toda a parceria. Na definição de Gronroos (1994, p. 2), marketing de relacionamento é: “[...] estabelecer, manter e melhorar relacionamento com clientes e parceiros para gerar lucro, de maneira que os objetivos possam ser alcançados. Para que isso ocorra, as duas partes precisam cumprir suas promessas". De acordo com Barreto (2007), para que o marketing de relacionamento ocorra, as duas partes, provedor e cliente, devem perceber algum benefício na relação.

Após a primeira aparição do termo, em 1983, outros autores, como Gummesson (1997), Gronroos $(1994,1996)$ e o próprio Berry $(1995,1996)$ começaram a contestar, na literatura, o marketing transacional como única forma de marketing. Esses autores acreditavam que as 
mudanças socioeconômicas sofridas na época pediam que os esforços de marketing passassem de esforços transitórios para ações voltadas para o marketing de relacionamento (Maxim, 2009).

Para Gronroos (1994), a globalização dos negócios e o crescimento do senso de importância de reter clientes fizeram com que houvesse essa mudança na percepção do que seria de fato marketing. Em um artigo mais recente sobre o tema, Brodie et al. (2010) afirmam que o marketing tradicional ou marketing transacional foi bastante contestado pelos principais acadêmicos da época e que, de tão intenso, o redirecionamento de ênfase promovido foi considerado uma mudança de paradigma. Kahn (2014) chamou esse processo de uma nova maneira de pensar da escola de marketing.

Saliby (1997) resume esse processo, ao apontar que o objetivo do marketing transacional, conhecido também como os 4 P's do marketing (preço, produto, praça e promoção), é conquistar novos clientes, enquanto o objetivo do marketing de relacionamento é manter clientes existentes. Barreto (2007, p. 12), enxerga o marketing de relacionamento como sendo um complemento do marketing transacional: "[o] marketing de relacionamento pode ser entendido como uma evolução do marketing. É, na realidade, um conjunto de práticas que visam direcionar a empresa mais claramente para o entendimento das necessidades de sua base de clientes".

A partir de sua primeira aparição, a teoria do marketing de relacionamento tem evoluído e se tornado uma prioridade na academia, bem como entre gerentes do mundo corporativo (Palmatier \& Steinhoff, 2019). Nesse sentido, Palmatier et al. (2016) destacam que houve um aumento considerável das publicações sobre marketing de relacionamento e livros de negócios populares sobre o tema nas últimas décadas, nos quais pesquisadores de marketing e gerentes continuam afirmando algo em comum: o relacionamento com o cliente é vital para desenvolver estratégias corporativas e melhorar performance.

Apesar da relevância que tem o marketing de relacionamento, Saliby (1997) acredita que não é recomendável implantá-lo em todas as empresas, mas somente nas que têm clientes de alto 
valor com um largo ciclo de vida. De acordo com o autor, empresas de serviços e empresas que vendem para outras empresas $(B 2 B)$ são as mais beneficiadas com a implementação do marketing de relacionamento. Crosby et al. (1990), por sua vez, apontam que apenas as empresas de serviço com produtos complexos deveriam aplicar ações de marketing de relacionamento.

Empresas prestadoras de serviço podem obter sucesso e gerar lucro de três formas: atraindo novos clientes, fazendo negócios com clientes existentes ou reduzindo a perda de clientes (evitando churn). Ao direcionar o orçamento do marketing para as ações de marketing de relacionamento, empresas podem lucrar com o aumento de seus contratos com clientes existentes (fazendo add-ons) e também com a manutenção dos clientes existentes, que não vão cancelar seus contratos (Berry, 1995). Outro objetivo do marketing de relacionamento é aumentar a satisfação do cliente, por meio da criação de um relacionamento entre as duas partes. Dessa forma, a empresa tem a oportunidade de melhorar sua performance. Para que esses benefícios ocorram, os relacionamentos devem ser desenvolvidos sempre pensando na satisfação do cliente (Beijou et al., 1998).

Nos dias de hoje, com o avanço da internet e a chegada da era digital, a maneira como empresas e clientes se relacionam tem mudado, e as relações têm passado de relações de humano-para-humano para relações digitais e impessoais. Manter relacionamentos sólidos com clientes nesse contexto se torna um desafio cada vez mais crítico (Palmatier \& Steinhoff, 2019).

Alguns fatores listados por Palmatier e Steinhoff (2019), a maioria originados com a chegada da era digital, mostram o porquê de ser essencial, na atualidade, que as empresas se esforcem para se relacionar bem com seus clientes e mantê-los leais. Alguns deles são: competição global, transição para economias baseadas em serviços e crescimento de mercados emergentes.

Competição global: 
A melhora na capacidade de comunicação e logística, promovida pela tecnologia, tem facilitado que clientes possam buscar informações sobre empresas, produtos, preços, entre outros, fazendo com que o mercado seja mais transparente e, consequentemente, competitivo. Isso aumenta a competitividade em nível global.

Transição para economias baseadas em serviços:

Em países desenvolvidos, a economia é predominantemente baseada em serviços, e a tendência é que empresas de serviços sejam cada vez mais comuns. Relações entre provedores e clientes, no setor de serviços, se dão de forma direta e sem intermediários. Como serviços são intangíveis e sua satisfação, difícil de medir (diferentemente de produtos), manter uma boa relação cliente-provedor se torna essencial.

Crescimento de mercados emergentes:

Para driblar a competição global e gerar lucro, empresas precisam vender para outros mercados. Os maiores mercados do mundo na atualidade, pelo menos em número de pessoas, são os emergentes. Existem muitas oportunidades de crescimento ao fazer negócio com países emergentes, principalmente para empresas que adotam o marketing de relacionamento. De acordo com uma pesquisa de relacionamento em mercados internacionais (Samaha \& Beck, 2014), táticas do marketing de relacionamento são mais exitosas em países emergentes, em comparação à sua eficácia em um mercado consolidado, como os Estados Unidos: são 28\% mais efetivas no Brasil, 20\% na Rússia, 71\% na Índia e 100\% na China.

De acordo com Palmatier e Steinhoff (2019), o marketing de relacionamento está em um momento de ressurgimento para acompanhar as tendências e mudanças do mercado global, incluindo os fatores citados acima, e está longe de atingir um estágio de maturidade e estabilidade. Apesar disso, os autores acreditam que o marketing de relacionamento continua sendo imprescindível para organizações sobreviverem nos dias de hoje, uma vez que pode 
oferecer vantagens competitivas significativas para vendedores na era digital (Palmatier \& Steinhoff, 2019).

\subsubsection{Relacionamento B2B}

De acordo com Rocha e Luce (2006), os estudos sobre marketing de relacionamento podem ser classificados em dois contextos: o relacionamento entre organizações e clientes individuais (Business to Customer), e entre organizações (Business to Business). Para Iacobucci e Ostrom (1996), a natureza desses dois tipos de relacionamento é bastante diferente: no contexto $B 2 B$, os relacionamentos são mais longos e intensos, enquanto acontece o contrário no $B 2 C$, em que eles têm menor intensidade e são mais curtos.

Algumas outras diferenças podem ser elencadas entre essas duas formas de relacionamento. No contexto $B 2 B$ : a) os clientes são organizações e não simplesmente pessoas; b) o número de clientes é consideravelmente menor; c) os produtos comercializados são mais complexos e levam mais tempo para ser desenvolvidos, e d) a interação com clientes é geralmente mais direta e mais intensa (Jussila, Kärkkäinen \& Aramo-Immonen, 2014). Nesta pesquisa, o foco será investigar, em um contexto $B 2 B$, como o marketing de relacionamento pode ajudar empresas de $\mathrm{SaaS}$, que costumam apresentar altas taxas de cancelamento de contrato (churn), a reter melhor seus clientes.

Analisando o relacionamento $B 2 B$ na perspectiva do cliente, de acordo com Palmatier e Steinhoff (2019), os clientes também buscam e valorizam características originadas do relacionamento, como, por exemplo, a redução na percepção do risco, o aumento da confiança no provedor, o aumento da colaboração entre cliente e provedor e o aumento da flexibilidade (principalmente no contexto de venda do serviço). Em um ambiente de interações $B 2 B$, provedores e clientes preferem conduzir negócios quando existe um benefício mútuo intrínseco na relação construída (Palmatier \& Steinhoff, 2019).

\subsubsection{Elementos do marketing de relacionamento}


Segundo Barreto (2015), são considerados como elementos do marketing de relacionamento os seus principais resultados e as principais formas com que ele atinge seus objetivos. É consenso entre os autores do marketing de relacionamento que seu principal resultado é a retenção da base de clientes existente, embora as formas para alcançar esse feito variem de autor para autor. Para Hennig-Thurau et al. (2002), existem vários construtos que podem ser discutidos no contexto do marketing de relacionamento, mas, segundo o autor, a literatura tem como foco apenas alguns deles: satisfação, qualidade, comprometimento e confiança. Neste trabalho, serão acrescentadas aos construtos indicados a comunicação e a personalização, que estão entre as principais maneiras de reter clientes no cenário $B 2 B$ por meio de práticas de marketing de relacionamento. No entendimento de Barreto (2015), pode-se definir esses aspectos como elementos de avaliação empresa-cliente.

\subsubsection{Satisfação}

Entender a necessidade dos clientes e melhorar a sua satisfação está levando empresas a desenvolver estratégias de marketing inovadoras para superar a acirrada competição do mercado (Noori \& Salimi, 2005). A satisfação do cliente foi definida por Oliver (1980) como a reação emocional do cliente entre o que lhe foi entregue pela empresa, ou prestador de serviço, e a sua expectativa em relação à entrega.

Para Beijou et al. (1998, apud Crosby \& Stevens, 1987), existem três tipos de satisfação: a satisfação do cliente relacionada ao ponto de contato dele dentro da empresa, com o serviço prestado e com a organização. Em um estudo feito com clientes no setor de seguros, Beijou et al. (1998) descobriram que a satisfação com o serviço teve um efeito mais importante que a satisfação com o ponto de contato ou com a organização. No mesmo artigo os autores chegaram à conclusão de que, para garantir a satisfação do cliente, os funcionários de vendas devem ser focados nas necessidades que ele apresenta e não apenas no interesse em realizar a venda.

Nos anos 1980, de acordo com Reichheld e Sasser (1990), não existia uma preocupação genuína por parte das empresas em satisfazer seus clientes. A partir daí, empresas de serviços 
começaram a perceber que precisavam melhorar a qualidade nos produtos e serviços, para que os clientes pudessem voltar e permanecer, aumentando seus lucros (Reichheld \& Sasser, 1990).

De acordo com Pride e Ferrel (2001), um cliente insatisfeito tende a perder a confiança no relacionamento, o que o leva a procurar outro fornecedor. Por isso, descobrir as principais expectativas do cliente e ser capaz de atendê-las leva à satisfação e, consequentemente, gera mais confiança. Morgan e Hunt (1994) defendem que as ações de marketing de relacionamento geram satisfação no cliente.

De acordo com Seybold (2002), a fidelidade do cliente não está estritamente atrelada à marca, mas arraigada nas experiências que os produtos e serviços proporcionaram. A chave para essa questão reside em criar experiências positivas que ajudam os clientes a confiar na empresa e continuar sendo clientes. O autor afirma, ainda, que a experiência do cliente é fundamental para que empresas conquistem o sucesso.

Para Gronroos (1990), a satisfação do cliente gera lucro para a organização. De acordo com o autor, com o aumento da qualidade do serviço prestado, a satisfação do cliente cresce e cria um forte relacionamento provedor-cliente, o que resulta em um relacionamento duradouro. De maneira resumida, ter clientes satisfeitos e retê-los ao longo do tempo gera lucro (Gronroos, 1994). Para ter clientes fiéis, de acordo com Ndubisi (2007), a empresa precisa cumprir com as promessas feitas a eles. Dessa maneira, não somente o satisfaz, mas também o retém e se assegura da receita oriunda de seu contrato em longo prazo.

Na visão de Saliby (1997), o marketing de relacionamento surge como uma nova abordagem de marketing para acompanhar as mudanças que vieram com os avanços da tecnologia. De acordo com esse autor, irão prosperar no novo ambiente empresarial, as empresas que tiverem a capacidade de satisfazer os seus clientes e torná-los fiéis. Quando existe uma relação de satisfação mútua, tanto o cliente quanto o provedor saem ganhando. O cliente evita custos com troca de fornecedor e o provedor evita custos desnecessários com procedimentos de verificação de qualidade, em inglês, quality costs (Gronroos, 1994). Outro objetivo do 
marketing de relacionamento é aumentar a satisfação do cliente, por meio da criação de um relacionamento entre as duas partes. Para que esses benefícios ocorram, os relacionamentos devem ser desenvolvidos sempre pensando na satisfação do cliente (Beijou et al., 1998).

Na visão de Gronroos (1994), existem diferentes maneiras de medir satisfação. Uma delas é fazer um survey ou questionário de satisfação entre a base de clientes. Esse procedimento, segundo o autor pode não ser tão acurado, já que a empresa pode estar perdendo vários clientes não satisfeitos, que estão rapidamente sendo repostos por novos clientes, e distorcendo o nível real de satisfação entre a base de clientes.

A outra maneira, mais qualitativa e acurada, seria mais comum em empresas $B 2 B$ de serviços, nas quais cada cliente tem pelo menos um contato de suporte dentro da empresa. Dessa maneira, a medição de satisfação se daria um para um: funcionário da empresa provedora $\mathrm{x}$ funcionário da empresa cliente. Nessa interação, a empresa provedora do serviço poderia, de maneira qualitativa, saber se o cliente está ou não satisfeito com a qualidade do serviço prestado e do produto oferecido (Gronroos, 1994).

Durante o estudo da teoria do marketing de relacionamento, percebe-se uma forte relação entre satisfação e qualidade. Para gerar satisfação no cliente, é preciso haver qualidade nos produtos e serviço oferecidos. Para Beijou et al. (1998), a satisfação do cliente é um pré-requisito para a qualidade do relacionamento. Para Barreto (2015), a satisfação é vista como um conceito mais amplo, sendo a qualidade um dos elementos formadores da satisfação.

\subsubsection{Qualidade}

A qualidade no marketing pode ser estudada em diferentes aspectos no contexto $B 2 B$. Entre eles, está a qualidade de um produto, de um serviço prestado ou a qualidade do relacionamento empresa-cliente ou vendedor-cliente, comumente estudada no marketing de relacionamento. Ao iniciar a pesquisa sobre qualidade tendo como cenário o marketing de relacionamento, foram encontrados os vieses relativos à qualidade no serviço prestado pela 
empresa a seus clientes, assim como à qualidade do relacionamento entre empresa e cliente. Não foi identificado, contudo, o viés que diz respeito à qualidade do produto oferecido. Portanto, a seguir, será visto o que a literatura comenta sobre esses dois aspectos da qualidade.

Para Gronroos (1990), um cliente satisfeito é um cliente que gera lucro para a empresa. De acordo com o autor, essa frase está baseada na ideia de que, se a empresa aumenta a qualidade do serviço prestado, a satisfação do cliente aumenta e, consequentemente, o lucro final (Gronroos, 1994). Percebe-se, aqui, que existe uma correlação entre qualidade, satisfação, forte relacionamento com o cliente, retenção do cliente e, finalmente, lucro. Toda essa cadeia de elementos começa pelo quesito qualidade.

Figura 1: Qualidade como fonte inicial de geração de lucro

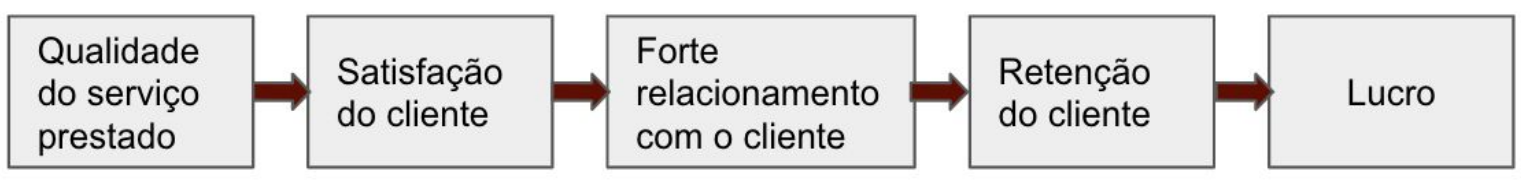

Fonte: adaptado de Gronroos (1994).

A qualidade no serviço prestado pela empresa ao seu cliente tem sido do interesse de autores do marketing de relacionamento. Para Lengnick-Hall (1996), a competição e dinâmica do ambiente de negócios global tem feito com que a qualidade seja um fator essencial para o sucesso de uma organização. Para Berry (1995), o aumento na qualidade do serviço resulta na lealdade do cliente.

Para Gronroos (1994), no marketing transacional, no qual o relacionamento com o cliente não é o fator mais importante, a qualidade técnica do produto é o fator principal. Já no marketing de relacionamento, o cenário é diferente. A empresa oferece ao seu cliente não somente um produto, mas o que o autor chama de "uma segunda dimensão em qualidade", inserida em aspectos como relacionamento, conhecimento, interação social, suporte. O produto e a tecnologia acabam não sendo o ponto mais importante. A qualidade do relacionamento 
oferecido ao cliente, ao final, acaba diferenciando as empresas fornecedoras de serviço. É claro que "isso não significa que a qualidade técnica pode ser negligenciada, mas não é apenas a única qualidade a ser considerada importante" (Gronroos, 1994).

Christopher e Payne (1991) definem qualidade como a junção do que o cliente espera com o que o cliente recebe em termos de serviço prestado a ele. É o que os autores chamam de "qualidade percebida". Já aquilo que foge disso seria o quality gap ou, em português, o que faltaria para que o cliente se sentisse satisfeito com o serviço prestado: "[o]s times de marketing e de gerência de qualidade devem trabalhar juntos para diminuir o 'quality gap', assim como todos os funcionários da organização. Isso não apenas ajuda a adquirir novos clientes, mas também a mantê-los" (Christopher \& Payne, 1991).

O que melhor define qualidade para Henning-Thurau et al. (2002) é a avaliação feita pelo cliente em relação à performance da empresa prestadora do serviço, com base em suas experiências e impressões. Woo e Ennew (2004) acreditam que a qualidade do serviço prestado por uma empresa e a qualidade do relacionamento que estabelece com seus clientes determinam a continuidade em longo prazo dos contratos entre compradores e vendedores. Em sua pesquisa, realizada em 2014, os autores defenderam a hipótese de que a qualidade do relacionamento entre vendedor e cliente no contexto $B 2 B$ tem impacto positivo na percepção de qualidade do serviço prestado ao cliente. Ou seja, vendedores que se relacionam bem com seus clientes teriam clientes que se dizem satisfeitos com o serviço prestado.

A competição crescente e em larga escala do mercado levou muitas empresas a buscar maneiras de se diferenciar dos seus competidores (Saliby, 1997). Uma das estratégias encontradas por essas empresas foi oferecer serviço de alta qualidade (Parasurman, Zeitham \& Berry, 1988). Parasurman, Zeitham e Berry (1998) desenvolveram um instrumento com 22 itens que, desde então, já passou por vários aperfeiçoamentos, para entender as percepções de clientes sobre a qualidade do serviço prestado, na época, por empresas de varejo. Barreto (2015) opina que, apesar de criticada, a ferramenta é importante para a avaliação da qualidade de serviços. 
Para Saliby (1997), é importante que as empresas entendam que os clientes estão cada vez mais exigentes e que estão olhando bastante para qualidade, não somente para o preço. Para o autor, é importante aproveitar todas as oportunidades para superar as expectativas dos clientes ao prestar um serviço, bem como saber administrar as expectativas do cliente quanto à qualidade do serviço antes de começar o atendimento.

De acordo com Lengnick-Hall (1996), contratar gerentes de relacionamento competentes, com bom comportamento e performance, causa um impacto significativo na maneira como os clientes enxergam a qualidade do serviço. Esses funcionários, de acordo com a autora, carregam uma grande responsabilidade quanto ao relacionamento: o fato de que o sucesso ou fracasso do atendimento depende deles.

\subsubsection{Confiança}

A base das ações de marketing de relacionamento é a confiança (Morgan \& Hunt, 1994). Quando a empresa confia no cliente e o cliente confia na empresa, um forte relacionamento é formado, o que acaba resultando na lealdade e, consequentemente, na retenção do cliente. Porém, segundo Berry (1995), uma parte não pode duvidar da intenção da outra: a comunicação precisa ser aberta, honesta e frequente. Além disso, segundo o autor, empresa e cliente devem estar dispostos a dar, e não somente a receber. Para que um forte relacionamento aconteça, os benefícios precisam ser mútuos (Czepiel, 1990).

Para Berry (1995), a confiança é um fator crítico na prestação de serviços, já que são intangíveis. Não se sabe como medir a qualidade de um serviço antes da compra e, muitas vezes, nem após a compra. É preciso haver confiança para que as duas partes estejam confortáveis com o serviço prestado, sabendo que existe benefício mútuo. A confiança existe em um relacionamento empresa-cliente, somente quando o cliente acredita que o prestador de serviço apresenta alto nível de integridade (Morgan \& Hunt, 1994).

De acordo com Saliby (1997), a confiança vem sendo apontada em muitos estudos como uma das ferramentas mais poderosas de marketing de relacionamento. A empresa deve tomar 
ações que gerem confiança nos seus clientes. Para que isso ocorra, ela deve: "a) possuir canais de comunicação abertos e transparentes com os clientes; b) oferecer garantias da qualidade do serviço, e c) demonstrar uma conduta correta e ética (Saliby, 1997, p.11).

No modelo de relacionamento de Henning-Thurau e Klee (1997), os autores apresentam o construto qualidade do relacionamento, juntamente com as variáveis denominadas percepção de qualidade relativa, comprometimento e confiança. Esses itens estariam situados entre a satisfação e a retenção do cliente. Para os autores, altos níveis de confiança e comprometimento ajudam na retenção do cliente.

Figura 2: Modelo de Henning-Thurau e Klee

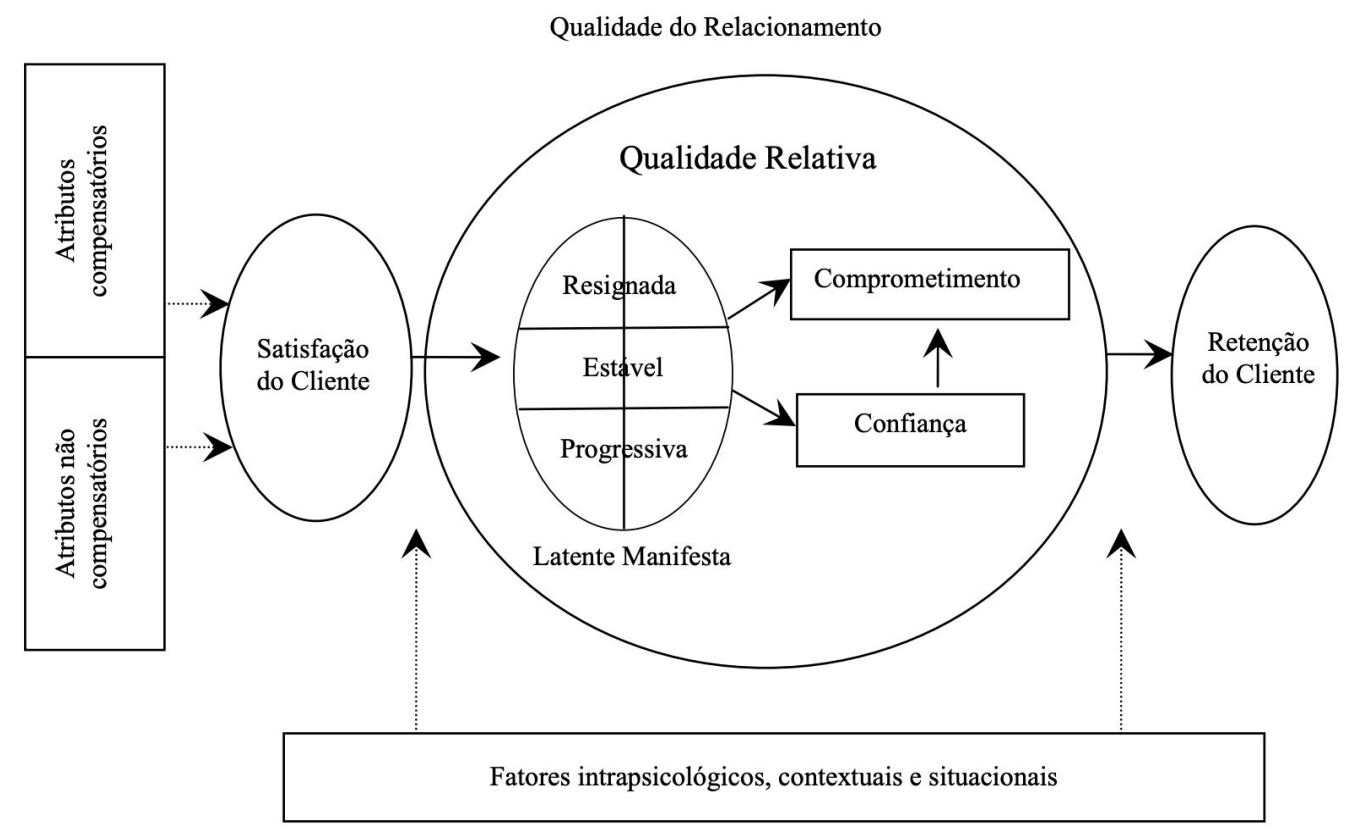

Fonte: Henning-Thurau e Klee, (1997).

\subsubsection{Comprometimento}

A confiança é importante no relacionamento entre empresa-cliente, mas, segundo Gronroos (1994), não é apenas isso que faz de um cliente um cliente fiel. Outro fator que ajuda na lealdade, segundo o autor, é o comprometimento existente no relacionamento. Gronroos (1994) define comprometimento como a intenção das duas partes de interagir uma com a 
outra. De acordo com o autor, comunicação gera confiança, e confiança gera comprometimento.

Morgan e Hunt (1994), de maneira semelhante, definem o comprometimento como o desejo de continuar o relacionamento com a outra parte, por considerar a relação importante. Em seu artigo sobre a teoria comprometimento-confiança, os autores mencionam que, para que o marketing de relacionamento seja aplicado com sucesso, é preciso haver um relacionamento que envolva confiança e comprometimento.

Para Geyskens et. al (1996), o comprometimento pode ser descrito como o interesse de um cliente pelo relacionamento com uma organização, com base na criação de vínculo emocional e na convicção de que o permanência no relacionamento vai trazer benefícios mútuos. Comprometimento existe quando o relacionamento é importante para as duas partes, e tanto empresa quanto cliente se esforçam para que a relação funcione (Gummensson, 2000).

Berry e Parasuraman (1991) acreditam que a base de qualquer relacionamento é o comprometimento mútuo. Em um estudo sobre a relação entre comprometimento e fidelidade, Pritchard, Havitz, e Howard (1999) descobriram que o comprometimento é um importante antecessor da fidelidade.

Gruen, Summers, e Acito (2000) desenvolveram um estudo para explicar como empresas usam ações de marketing de relacionamento para atingir comprometimento por parte do cliente. No artigo, definiram que existem três tipos de comprometimento: a) comprometimento contínuo, associado com o custo de deixar a organização (custo social, econômico, entre outros.); b) comprometimento normativo, relacionado ao senso de obrigação moral de uma pessoa em continuar o relacionamento com a empresa, e c) comprometimento afetivo, focado no apego emocional de uma pessoa à organização, quando ela se sente favorável sobre a empresa.

Gummesson (2000, p. 16) indica que existem três níveis de comprometimento: "(...) o nível 1 indica a atração dos clientes por preços baixos. No nível 2, o relacionamento se aprofunda 
com maior comunicação entre as partes. No nível 3, os envolvidos colocam recursos no relacionamento e estão altamente comprometidos."

\subsubsection{Comunicação constante e personalização}

O marketing de relacionamento ressalta a importância da interação e comunicação contínua entre o cliente e a empresa, para manter um relacionamento de longo prazo (Morgan \& Hunt, 1994; Gronroos et al., 1994; Berry, 1983; Saliby, 1997).

A intensidade na comunicação empresa-cliente, segundo Czepiel (1990), pode dar ao cliente a percepção de que ele possui para a empresa um status especial. Berry (1995) menciona a tecnologia como uma facilitadora no processo de comunicação, já que possibilita canais de comunicação de duas vias: empresa-cliente e cliente-empresa.

A personalização e a customização no marketing de relacionamento envolvem comunicação frequente com o cliente, chamá-lo pelo nome durante as interações, a manutenção de um mesmo executivo de venda para lidar com o cliente, assim como a elaboração de atividades de entretenimento para clientes, como festas ou seminários (Berry, 1995). Para Parasuraman e Berry (1991), o cliente prefere comunicações frequentes e personalizadas, de preferência tendo o mesmo ponto de contato dentro da empresa. O cliente quer ser contatado pelo representante da empresa, ao invés de ele mesmo ter que iniciar a comunicação: "eles querem um parceiro, alguém que os conheça e que se importe com eles" (Parasuraman \& Berry, 1991, p. 43).

O termo "manutenção" está presente nas principais definições da literatura do marketing de relacionamento, mostrando a importância de não somente criar e desenvolver relacionamento, mas manter-se em comunicação constante com o cliente para não perdê-lo. É parte do marketing de relacionamento manter o constante contato com o cliente, fornecendo informação sobre o serviço e avisando sobre qualquer mudança com antecedência, além de comunicar de maneira rápida e proativa caso algum problema ocorra (Ndubisi \& Wah, 2005). De acordo com Ndubisi e Wah (2005), quando existe uma comunicação constante entre uma 
empresa e seus clientes, o resultado é um melhor relacionamento entre as duas partes e, consequentemente, clientes mais fiéis.

Figura 3: Comunicação como fator de fidelização de clientes

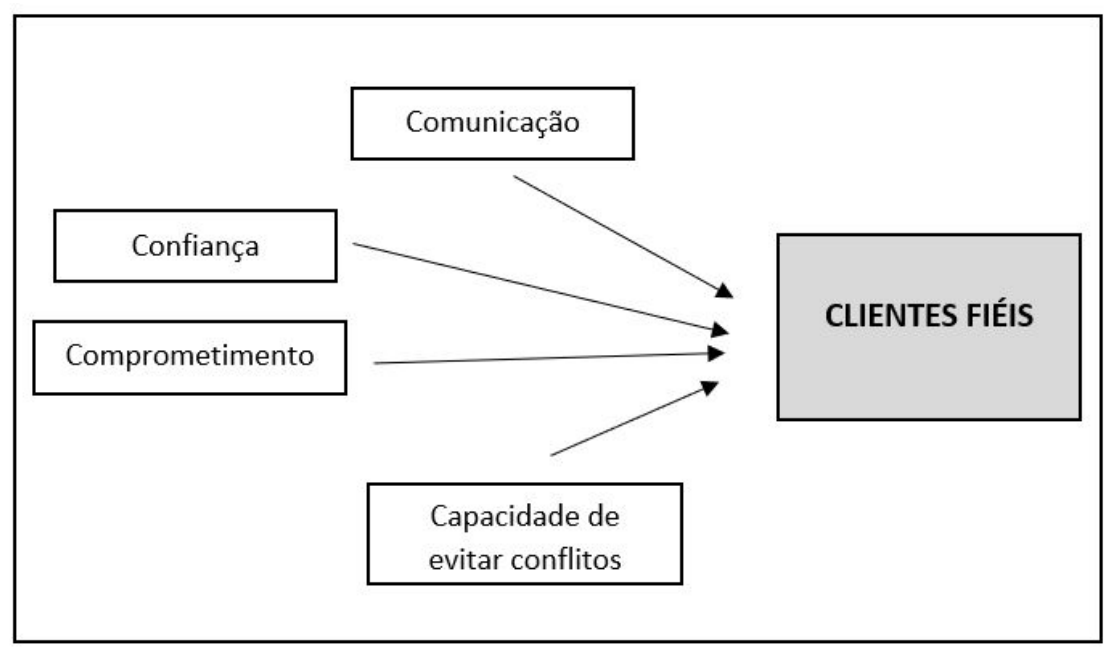

Fonte: adaptado de Ndubisi e Wah, (2005).

Para Barreto (2007), o marketing de relacionamento permite que a empresa capte informação relevante de seus clientes por meio da comunicação, que deve ser feita de forma contínua ao longo de toda relação, e não de maneira pontual ou desvinculada. De acordo com Andersen (2001), existem indicadores que mostram que a comunicação entre uma empresa e seus clientes têm um impacto direto nos aspectos centrais do marketing de relacionamento, como confiança e comprometimento, por exemplo.

Vários autores que escreveram e escrevem sobre marketing de relacionamento estão de acordo que a comunicação é um aspecto fundamental no desenvolvimento do relacionamento com clientes (Andersen, 2001). De acordo com Duncan e Moriarty (1998), a comunicação no marketing de relacionamento não deve envolver somente a persuasão do cliente, mas deve estar atenta em informar, escutar e responder.

Segundo Andersen (2001), no relacionamento contínuo entre empresas e clientes, websites e internet, de maneira geral, podem ajudar na frequência de comunicação e interação, 
tornando-se recursos importantes. Outra tática que ajuda na comunicação, segundo o autor, é a reunião presencial no escritório do cliente. A interação face-to-face é a mais benéfica, principalmente quando se dá no escritório do cliente, onde existe maior probabilidade de entender seus desafios (Andersen, 2001).

No marketing de relacionamento, o quesito comunicação com o cliente é o ponto de maior relevância, já que é por meio da comunicação que o cliente ganhará confiança no provedor. As empresas que querem implementar uma estratégia de marketing de relacionamento precisam buscar atentamente criar uma estratégia de comunicação com clientes: que canais serão usados e em que fase do processo (Andersen, 2001).

Uma boa prática seria aproveitar o suporte da tecnologia de informação e testar ideias de novos produtos/serviços diretamente com os clientes e em tempo real, como mais uma estratégia de comunicação. Saliby (1997, p. 10) atesta que o marketing de relacionamento propicia algumas ações - graças ao avanço da tecnologia - que possibilitam melhorar a experiência do cliente: “[...] registrar os padrões de comportamento dos clientes, aumentar os canais de comunicação com clientes e fornecedores, personalizar os serviços prestados e minimizar a probabilidade de erros".

\subsubsection{Churn}

Retenção e lealdade de clientes é um tema que vem recebendo atenção em muitas indústrias (Mutanen, 2006). Reter clientes vêm sendo considerado um dos desafios mais críticos para as empresas (Migueis et al., 2012), já que a lealdade e, consequentemente, a retenção de clientes, traz lucro em curto e longo prazo, mantendo as organizações financeiramente saudáveis. $\mathrm{O}$ churn (termo em inglês ainda sem tradução exata para o português), que significa interrupção do contrato de um cliente com uma empresa, acaba sendo, nesse contexto, o que as organizações mais querem evitar.

De acordo com Migueis et al. (2012), reter um cliente existente é mais vantajoso financeiramente que adquirir um novo cliente. Na busca pela retenção, as empresas 
perceberam que, nos dias de hoje, com o aumento da concorrência, a chegada da tecnologia da informação e a internet, a quantidade de informações disponível para o cliente aumenta, assim como a facilidade na troca de fornecedor (Barreto, 2007).

Para Bonfiglio e Alon (2017), manter a base de clientes e evitar o churn vai aumentar significativamente a receita da empresa. Para os autores, a experiência que o cliente tem com os produtos e/ou serviços de um fornecedor é um bom indicativo para saber se o churn vai acontecer ou não. Já a falta de uso do produto e falta de engajamento do cliente podem ser um sinal de que esse cliente eventualmente não renovará seu contrato.

A presença e impacto do churn varia de indústria para indústria. O setor de bancos (varejo) é caracterizado por clientes que permanecem com o mesmo fornecedor por um longo período de tempo, o que produz, na perspectiva da empresa, um ambiente estável e propício no relacionamento com clientes (Mutanen, 2006). Já o setor de software, em especial SaaS, estudado nesta pesquisa, sofre de altas taxas de churn, já que a alta concorrência e outros fatores, que serão apresentados a seguir, fazem com que o cliente se torne mais suscetível à troca de fornecedor.

Para evitar o churn, que vem sendo um problema e um dos principais desafios enfrentados por empresas ao redor do mundo, e sobreviver em um mercado cada vez mais competitivo, muitas empresas estão aplicando técnicas de predição e análise de churn (Xie et al., 2009). De acordo com Xie et al. (2009), técnicas de predição de churn se tornaram um foco em bancos chineses, que querem reter seus clientes satisfazendo todas as suas necessidades.

\subsection{Software as a Service (SaaS)}

Software as a Service (SaaS) ou software como serviço é o tipo mais comum de computação na nuvem, tecnologia que vem sendo tema recorrente na mídia e em estudos acadêmicos (Vieira, Meirelles \& Cunha, 2005) e que vem transformando a maneira como serviços de tecnologia da informação (TI) são utilizados. Uma das maneiras de definir se um negócio é baseado no modelo $S a a S$ ou não é observar seu enquadramento nos seguintes requisitos: não 
necessita download ou instalação, sendo possível o acesso por qualquer navegador; o cliente faz pagamento por assinatura, geralmente mensal ou anual; os dados não ficam hospedados na máquina do cliente, mas na nuvem (internet) ou cloud; e não é preciso fazer upgrades manuais, já que isso é feito por meio da internet e é de responsabilidade do provedor do serviço.

De acordo Brown e Nyarco (2013), SaaS pode ser considerado um modelo de negócio ou um modelo de entrega de aplicativo. No contexto $B 2 B$, o software aplicativo, como também é chamado, pode ser comprado por uma empresa como um serviço, dispensando custos altos de instalação e treinamento de equipes, para resolver diversos desafios do seu dia a dia. O SaaS, assim como todos os outros segmentos de cloud - Infrastructure as a Service (IaaS), Platform as a Service (PaaS), Database as a Service (DaaS), entre outros -, pode ser acessado de qualquer computador do mundo, sem precisar de instalação prévia.

O GSuite (Google Apps) é um dos softwares aplicativos entregue no modelo SaaS mais conhecidos. Empresas que contratam o serviço $B 2 B$, que inclui e-mail, aplicativo de videoconferência, agenda, entre outros, pagam para o Google uma quantia mensal (pacote básico começando por $\mathrm{R} \$ 24,30$ ) por funcionário para dar-lhes acesso aos aplicativos.

O SaaS promete transformar a forma como as pessoas constroem, vendem, compram e utilizam softwares, além de agregar várias vantagens ao cliente e ao fornecedor, tais como: implementação rápida, menor custo inicial, menor custo de manutenção e facilidade de uso (Chong \& Carraro, 2006, p. 3).

Chou e Yang (2015) alegam que existem várias vantagens para empresas que decidem pela adoção do uso de $S a a S$, mas também algumas desvantagens provocadas pelo limite na customização do software e no baixo investimento específico no relacionamento com o cliente. Entre as desvantagens acarretadas pela falta de investimento no relacionamento com o cliente mencionadas por Chou e Yang (2015), estão: (a) dificuldades na utilização do software sofridas pelo cliente logo após a compra, influenciando na lealdade, continuidade do uso e 
exploração inicial da ferramenta; (b) incerteza, caracterizada pela imprevisibilidade da qualidade do serviço, e (c) inexistência de um serviço local de atenção ao cliente, entre outros.

O SaaS continua sendo o maior segmento do mercado de cloud, com um crescimento de receita esperado de 17,5\%, chegando a 110 bilhões de dólares em 2020. Estima-se que o setor fature cerca de 143 bilhões de dólares em 2022, mais que o dobro do arrecadado em 2018 (Gartner, 2019).

Tabela 1 - Previsão do Crescimento do Setor de SaaS (milhões de dólares)

\begin{tabular}{|l|l|l|l|l|l|}
\hline & $\mathbf{2 0 1 8}$ & $\mathbf{2 0 1 9}$ & $\mathbf{2 0 2 0}$ & $\mathbf{2 0 2 1}$ & $\mathbf{2 0 2 2}$ \\
\hline $\begin{array}{l}\text { Cloud Business Process Services } \\
\text { (BPaaS) }\end{array}$ & 45.8 & 49.3 & 53.1 & 57.0 & 61.1 \\
\hline $\begin{array}{l}\text { Cloud Application Infrastructure } \\
\text { Services (PaaS) }\end{array}$ & 15.6 & 19.0 & 23.0 & 27.5 & 31.8 \\
\hline Cloud Application Services (SaaS) & 80.0 & 94.8 & 110.5 & 126.7 & 143.7 \\
\hline $\begin{array}{l}\text { Cloud Management and Security } \\
\text { Services }\end{array}$ & 10.5 & 12.2 & 14.1 & 16.0 & 17.9 \\
\hline $\begin{array}{l}\text { Cloud System Infrastructure } \\
\text { Services (laaS) }\end{array}$ & 30.5 & 38.9 & 49.1 & 61.9 & 76.6 \\
\hline Total Market & $\mathbf{1 8 2 . 4}$ & $\mathbf{2 1 4 . 3}$ & $\mathbf{2 4 9 . 8}$ & $\mathbf{2 8 9 . 1}$ & $\mathbf{3 3 1 . 2}$ \\
\hline
\end{tabular}

Fonte: Gartner, 2019.

Software tradicional $x$ Software as a Service (SaaS)

A principal diferença entre o software tradicional e o SaaS é a maneira como o software é entregue ao usuário final. Os vendedores de software tradicional vendem cópias de software para serem instaladas no computador do cliente - quanto mais cópias são vendidas, maior é a receita da empresa. Já as empresas que vendem SaaS têm sua receita baseada em subscriptions (assinaturas) pagas por seus clientes para utilizar o software como um serviço. 
Para Solomon (2019), outra diferença entre SaaS e o software tradicional é que o SaaS precisa, mais do que no outro modelo, manter seus clientes felizes a qualquer custo. Para atingir um alto ROI (retorno no investimento), o foco de empresas de SaaS precisa ser no cliente, já que sua receita vem em sua maioria de assinaturas de clientes existentes. Já o foco das empresas vendedoras de software tradicional está no produto.

Existem empresas provedoras de $S a a S$ que oferecem seu software por assinatura para clientes individuais $(B 2 C)$ e também empresas que vendem para outras empresas (B2B). Neste estudo, o foco será na venda de $\operatorname{Sa} a S B 2 B$.

\subsubsection{Relacionamento High Touch $x$ Low Touch}

O ponto de partida para qualquer empresa, quando estabelecida, é obter lucro por meio da venda de seus produtos e/ou serviços para o maior número de clientes possível, aumentando sua base de clientes pouco a pouco. A princípio, esse é o caso de empresas provedoras de $S a a S$; a diferença é que, nesse modelo, não basta apenas adquirir clientes, é preciso retê-los a qualquer custo (Skok, 2016). Empresas de SaaS geram lucro por meio de receita recorrente quando seus clientes utilizam seu software no decorrer dos meses/anos. Como a aquisição dos clientes nesse setor é muito cara, a retenção dele é essencial, já que, só após doze meses, em média, o investimento inicial para adquirir o cliente é recuperado (Yizhe et al. 2107). De maneira resumida, a aquisição de clientes é importante no setor de $S a a S$, mas não menos que a retenção deles (Le, 2019). Para reter clientes no contexto $B 2 B$, mais do que nunca, é preciso saber relacionar-se com eles.

Com o avanço da tecnologia da informação e o uso de computadores e internet, a maneira como as empresas se relacionam com seus clientes no setor $B 2 B$ tem mudado (Palmatier \& Steinhoff, 2019). Nos últimos anos, no setor de tecnologia, empresas têm inserido mais e mais o conceito self-service para os seus clientes, criando o que Salomann (2007) chamou de relacionamento "high tech", quando existe menor interação humana na relação empresa-cliente. O contrário, quando existe uma maior interação humana no relacionamento com clientes, foi descrito pelo autor como relacionamento "high touch". 
Neste trabalho, os tipos de relacionamento entre uma empresa e seus clientes existentes (ou base de clientes) no contexto $B 2 B$ vão ser apresentados como "high touch" - quando há uma interação mais próxima entre empresa e cliente - e "low touch", quando o contato é muito mais online, self-service e com pouca interação humana.

O modelo de negócio do SaaS, diferentemente do modelo de venda de software tradicional, tem sido caracterizado por si só como um modelo que fez a transição do "high-touch, high-margin, high-commitment" (alto contato, alta margem e alto comprometimento) para o "low-touch, low-margin, low-commitment" (baixo contato, baixa margem e baixo comprometimento) (Armbrust, 2010).

De acordo com Luoma (2013), empresas de SaaS usam de seus canais online para aumentar a adesão de ações self-service pelos seus clientes e, como consequência, aumentar suas margens de lucro, oferecendo o mínimo de serviço extra possível (relacionamento high touch). Tyrväinen and Selin (2011), por outro lado, acreditam que empresas de SaaS devem também oferecer aos seus clientes consultoria, integração, customização do produto e uma relação humana mais próxima com seus clientes (relacionamento high touch).

\subsubsection{Causadores de Churn em empresas de SaaS}

O churn acontece quando um cliente cancela a assinatura que estava pagando a uma empresa provedora de SaaS. De acordo com o mais novo relatório da KeyBanc Capital Markets (2018), que entrevistou 385 empresas privadas de SaaS ao redor do mundo, a taxa de churn anual dessas empresas gira em torno de $13,2 \%$.

De acordo com Skok (2016), o churn, cancelamento de assinatura por parte do cliente, é algo comum e que sempre vai ocorrer em empresas de receita recorrente. $\mathrm{O}$ que não pode acontecer é que a taxa de churn seja maior que a receita gerada pela aquisição de novos clientes + upsell (aumento de contrato existente) + crossell (aumento do contrato através de um produto complementar). 
Sustentar uma taxa de churn controlada é essencial para qualquer negócio de $S a a S$. De acordo com Bonfiglio e Alon (2017), manter clientes por um longo período de tempo e evitar churn é o que irá, de maneira substancial, aumentar a receita de uma empresa. Ainda de acordo com os autores, é preciso ficar atento aos sinais que o cliente mostra logo antes de declinar o contrato.

Foram encontrados, na literatura, três fatores principais que levam empresas de $\operatorname{Sa} S$ a perder clientes e elevar suas taxas de churn, como será visto a seguir.

\section{A) CLIENTE INSATISFEITO COM O SERVIÇO PRESTADO}

A prestação de serviço de qualidade é um desafio característico de empresas do setor de SaaS. Da mesma maneira, os clientes de SaaS também apresentam algo em comum: trazem consigo expectativas específicas relacionadas ao atendimento que vão receber do provedor (Benlian et al., 2010).

De acordo com Suthar (2019), o suporte dado ao cliente para garantir sua satisfação é a chave do sucesso de uma empresa de SaaS. Ter um bom serviço de suporte ao cliente dá à empresa uma vantagem frente aos competidores que pode ser ainda mais importante que o preço. A maioria dos clientes estão dispostos a pagar até $25 \%$ a mais para ter uma melhor experiência (Suthar, 2019).

Segundo Benlian et al. (2010, p.2), apesar de toda a facilidade trazida pelo SaaS (custo mais baixo, elasticidade operacional, facilidade de implementação, entre outras), algo está impedindo o sucesso do modelo: a qualidade do atendimento prestado ao cliente não está satisfazendo suas expectativas: “[...] como os contratos são pagos através de assinaturas de períodos curtos e a troca de provedor é na verdade muito barata, fica mais fácil para o cliente dar churn e passar a assinar o software de outro provedor". Bonfiglio e Alon (2017) concordam que a experiência de um cliente ao usar um aplicativo de software no modelo 
SaaS vai determinar se ele continuará assinando o serviço ou se aquela compra resultará em churn.

De acordo com Solomon (2019), o fato de que muitas empresas provedoras de SaaS têm o produto como foco, e não a experiência do cliente, faz com que muitos clientes desistam de assinar o serviço. Para o autor, ao invés de focar no produto, é preciso focar em deixar os clientes felizes e próximos, para que não cancelem a assinatura. Com isso, a empresa pode receber receita não somente no primeiro ano de uso, mas durante todo seu percurso como cliente e assinante. Não basta somente adquirir o cliente e dar acesso às licenças, é preciso criar uma parceria, nutri-la, fazer o onboarding e suas renovações, para garantir sua experiência satisfatória (Gentilini, 2018).

Se o atendimento apresenta níveis de satisfação muito baixos, usuários tendem a descontinuar o uso de SaaS, enfatizando a importância de que os gestores entendam o quesito satisfação (Chou \& Yang, 2015). Para entregar serviços satisfatórios, empresas devem ganhar a confiança de seus clientes e prestar serviço de alta qualidade (Song et al. 2007). Bonfiglio e Alon (2017) acreditam que, quando uma empresa de SaaS apresenta altas taxas de churn, o primeiro passo é investigar o que pode ser melhorado no time de customer success, departamento que cuida da experiência e treinamento do cliente. Mesmo assim, segundo os autores, todos os outros times envolvidos na venda de SaaS devem garantir que o cliente tenha uma boa experiência com o serviço, para evitar churn.

Figura 4: Responsáveis por garantir a boa experiência do cliente 


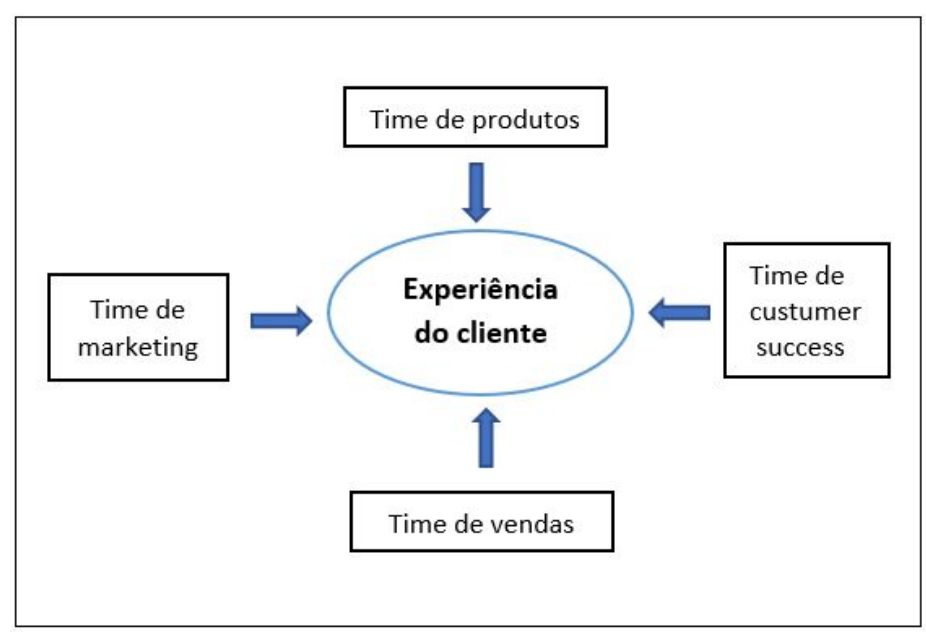

Fonte: adaptado de Bonfiglio e Alon (2017).

Em suas pesquisas, Chou e Yang (2015) focaram em descobrir o que gera satisfação em clientes de $\operatorname{SaaS}$ no ambiente corporativo $B 2 B$, justificando que a satisfação tem o papel fundamental de impedir que o cliente cancele o serviço e migre para um competidor. Segundo os autores, a falta de pesquisas sobre o que leva um cliente de $S a a S$ a ficar insatisfeito com o serviço e abandonar o provedor acaba aumentando as taxas de churn e limitando o avanço do SaaS no mercado. Para garantir a satisfação do cliente e a continuidade das assinaturas pagas por ele, de acordo com Ericksson (2013), o relacionamento entre o provedor e o cliente no contexto $B 2 B$ deve ser constante e o provedor de $S a a S$ deve entrar em contato com o cliente regularmente, mostrando interesse por seus resultados.

Para que as empresas clientes de SaaS não cancelem o serviço, os provedores do modelo precisam encontrar seus pontos fracos e investigar quais são os fatores cruciais que levam seus clientes a continuar pagando pelas assinaturas (Belian et al., 2010). Skok (2016) sugere que empresas de $S a a S$ enviem questionários ou surveys para seus clientes, com o objetivo de medir sua satisfação. A maneira recomendada pelo autor para medir a "felicidade" do cliente é o Net Promoter Score (NPS).

B) QUALIDADE DO SERVIÇO PRESTADO: ONBOARDING MAL-EXECUTADO 
De acordo com Cardoso (2017), qualquer pessoa que acesse uma plataforma ou aplicativo on-line pela primeira vez precisa ter uma ideia clara de como entrar na plataforma, como ela funciona e quais são os benefícios que possui. Isso é considerado importante, porque dá a noção ao usuário de como usar o serviço, fazendo com que entenda seu valor e se mantenha engajado com o uso do produto.

Existem vários tipos de onboarding para diferentes empresas de SaaS. Alder (2016), especialista em estratégias de customer success, atesta que, para algumas empresas provedoras de SaaS, o onboarding pode ser feito sem interação humana (low touch); para outras empresas, de produto mais complexo, um funcionário precisa conduzir o onboarding (high touch).

Para Belian et al. (2011), para que o setor de SaaS continue crescendo, é preciso haver qualidade no serviço prestado por essas empresas. Um bom onboarding é sinal de que a empresa está prestando ao cliente um alto nível de serviço, já que, desde o início, está se preocupando com a aprendizagem do cliente e deixando-o confortável com o software adquirido.

Para manter taxas de churn baixas, empresas de $\operatorname{SaaS}$ precisam descobrir quais são os pontos fracos da sua prestação de serviços e os fatores que provocam churn. O onboarding mal-executado é um desses fatores (Payne 2016). Segundo Skok (2016), um dos principais estudiosos do processo de venda e relacionamento com o cliente no setor de $S a a S$, existem duas razões principais que fazem com que essas empresas tenham elevadas taxas de churn no cenário $B 2 B$. Uma delas é a falha em fazer um processo de onboarding satisfatório com o cliente; a outra é a perda do champion, funcionário da empresa compradora do SaaS que defendeu desde o princípio que a compra do serviço seria uma boa opção.

Ademais, segundo Skok (2016), muitas empresas de SaaS tentam evitar o churn de seus clientes logo antes da data de renovação do contrato, para salvar a renovação e garantir receita. Contudo, para o autor, o momento de salvar o contrato seria no início, no processo de onboarding, quando o cliente ainda está interessado no uso do produto e disposto a se esforçar 
para aprender a usá-lo. Skok (2016) afirma que, se a empresa de SaaS falha em conquistar seu cliente no processo de onboarding, este vai entender que o produto não é tão bom quanto esperava e, quando começar a pensar dessa maneira, vai ser muito difícil convencê-lo a usá-lo novamente (Skok, 2016).

Ao listar alguns causadores de churn em empresas de SaaS, Markidan (2015) também aponta o onboarding malsucedido como um deles. Para o autor, existem dois marcos importantes na trajetória do cliente, e grande parte do churn se dá entre esses dois acontecimentos: o momento que em que ele assina o contrato, e o momento no qual consegue seu primeiro sucesso com o produto. De acordo com o autor, entre esses dois acontecimentos, deveria haver um onboarding de qualidade, para que os clientes não fiquem confusos com a ferramenta e vejam valor no que lhes foi oferecido. Com isso, eles não perderão o interesse.

Figura 5: Onde acontece o processo de onboarding

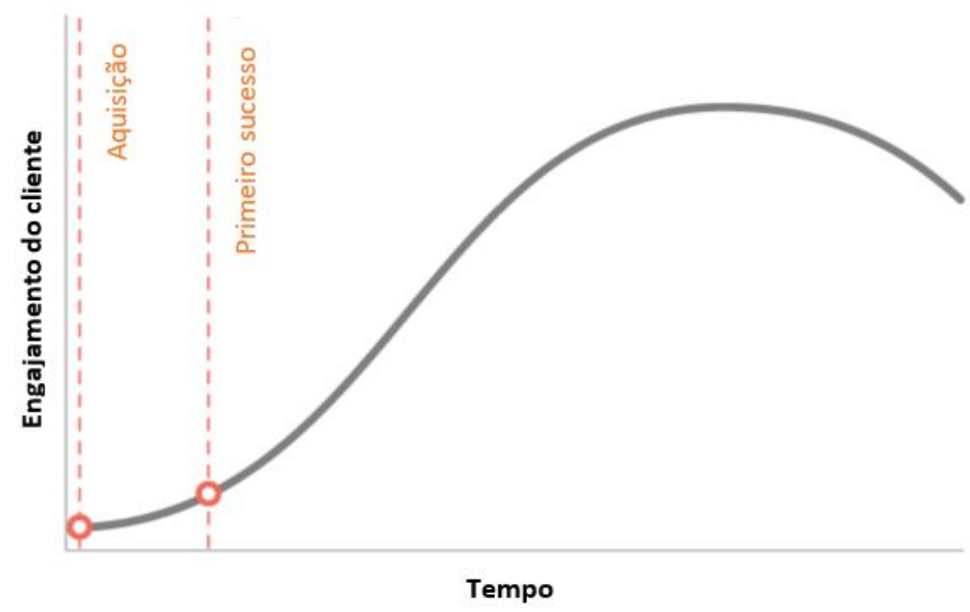

Fonte: adaptado de Markidan, (2015).

De acordo com Sjoberg e Winback (2017), no mercado de SaaS, é importante apoiar e ajudar os clientes a enxergar o valor do produto e do serviço prestado logo depois a assinatura do contrato, de preferência o quanto antes. Não dar o valor merecido ao processo de onboarding e não enxergá-lo como parte vital da jornada do cliente faz com que empresas de SaaS aumentem suas taxas de churn e percam a oportunidade de transformar novos clientes em 
usuários fiéis (SJÖBERG; WINBÄCK, 2017). De acordo com Hulick (2014), um onboarding é considerado bem-feito, quando o cliente começa a utilizar bem o serviço logo após fazê-lo.

Se os clientes de SaaS ficam confusos sobre qual é o passo a passo de utilização da ferramenta antes de começar a utilizar o produto, significa que o onboarding conduzido foi malfeito (Rai, 2018). De acordo com Rai (2018), um bom onboarding é crítico para ter como resultado uma boa experiência do cliente. Se o cliente precisa retomar o contato com o provedor de SaaS para entender por onde começar, é porque a empresa falhou em prestar a ele uma boa experiência e um bom serviço.

Rai (2018) acrescenta, ainda, que clientes SMB (small and medium business), ou seja, clientes de menor porte, merecem mais atenção dos provedores de SaaS e precisam dedicar mais tempo ao fazer seus onboardings. Essas empresas têm menos acesso à tecnologia e, muitas vezes, estão tendo seu seu primeiro contato com o modelo de software como serviço. Nesses casos, segundo o autor, não se pode correr o risco de que os clientes se frustrem e cancelem seus contratos antes mesmo de começarem a usar o SaaS. Um onboarding malsucedido pode destruir taxas de retenção de clientes, e é papel das empresas de SaaS fazer essa transição de não-cliente para cliente da maneira mais leve possível, para que todo o investimento em sua aquisição valha a pena (Markidan, 2015).

\section{C) FALTA DE COMUNICAÇÃO CONTÍNUA COM O CLIENTE}

Entretanto, um bom onboarding, sozinho, não garante que o cliente continue pagando pela assinatura de um SaaS. De acordo com Markidan (2015), o onboarding ajuda o cliente a obter seu primeiro sucesso com o produto, mas é preciso ser feito um trabalho de comunicação contínua para não perdê-lo. Para o autor, se o cliente para de receber contatos da empresa, e essa para de fazer esforços para mostrar a ele o valor da solução, a tendência é que seu ciclo de vida seja mais curto.

De acordo com Balieiro (2019), não ter uma equipe especializada e treinada exclusivamente em fazer clientes obterem sucesso é um dos principais causadores de churn. Essa equipe, 
chamada de customer success, age indicando a maneira correta de usar a ferramenta, promovendo treinamentos e mostrando como extrair o melhor do produto. Equipes de customer success têm se tornado cada vez mais comuns para fazer esse papel de comunicação contínua com o cliente, principalmente em empresas SaaS, que precisam evitar o churn para que se tornem empresas lucrativas (Balieiro, 2019).

Em seu guia Customer success: the definitive guide, Murphy (2018) defende que a prática do customer success têm suas raízes e origens no modelo SaaS, que, por natureza, precisa ter uma equipe dedicada ao contínuo esforço para engajar clientes e evitar o churn. Porém, o que o autor tem identificado é que empresas que não seguem o modelo SaaS (empresas de tecnologia, no geral) começaram também a dar a atenção merecida ao cliente e deixaram de focar apenas no produto e nas suas funcionalidades.

Para evitar o churn, é preciso entender os objetivos do cliente e fazer o possível para ajudá-lo a alcançar seus objetivos iniciais. Ajudar clientes a se manter constantemente engajados com um produto, serviço ou plataforma é o papel da equipe de customer success (Mehta et al., 2016). De acordo com Murphy et al. (2016), os executivos de customer success e seu contato constante com os clientes são essenciais para que empresas de SaaS tenham sucesso e possam continuar nutrindo a base de clientes existentes e evitando churn.

Ainda de acordo com Murphy (2017), o engajamento ou engagement acontece quando o cliente está percebendo valor na ferramenta entregue por meio de SaaS durante todo seu ciclo como assinante. Para o autor, o valor não está somente no produto e suas funcionalidades, mas na capacidade que a empresa tem de manter o cliente engajado. $\mathrm{O}$ foco, para ele, deve estar no cliente, e não no produto. Para isso, Murphy (2017) propõe que a equipe de customer success possa medir o engajamento do cliente, o que não é fácil, mas necessário.

Bonfiglio e Alon (2017) esclarecem que uma das razões para que um cliente deixe de assinar um SaaS e mude para o serviço do concorrente é a falta de contatos, interações e ações que geram engajamento. Conversas constantes entre clientes e executivos do time de customer success, por mais simples que sejam, podem ajudar a diminuir as taxas de churn. Ainda de 
acordo com os autores, o customer success é responsável por manter o cliente em longo prazo e, por conta de sua importância, tem se tornado um departamento independente, que apoia o time de vendas e de marketing (Bonfiglio \& Alon, 2017).

\subsubsection{O marketing de relacionamento na prevenção do churn em SaaS}

Nesse momento, já com uma clara ideia dos principais causadores de churn em empresas de SaaS B2B, pode-se identificar, nos elementos do marketing de relacionamento, sugestões para minimizar os cancelamentos de contrato no setor. Segundo Barreto (2007), são considerados como elementos do marketing de relacionamento seus principais resultados e as principais formas como o marketing de relacionamento é capaz de atingir seus objetivos.

Nesta seção, será muito comum o uso do termo "gerente de relacionamento", conhecido também por gerente de contas, executivo de pós-venda, key account, ou relationship manager. Em uma empresa de SaaS, o gerente de relacionamento é o contato principal do cliente após a venda, consistindo no seu suporte durante o tempo de contrato. Ele será o funcionário responsável pelo treinamento, atendimento de solicitações (caso o cliente tenha algum problema técnico), dúvidas sobre a forma de pagamento, upsell (aumento de contrato), assim como qualquer outra solicitação. O papel do gerente de relacionamento também pode ser considerado estratégico, já que, além de suporte meramente técnico, compartilha com o cliente o uso de dados e insights sobre a utilização da ferramenta; monta um plano de ação para o tempo de contrato e faz reuniões periódicas com o cliente, com o objetivo de auxiliá-lo a chegar ao seu objetivo final.

\section{Clientes insatisfeitos com o serviço prestado}

Provedores de SaaS lidam constantemente com clientes que cancelam seus contratos por estarem insatisfeitos. Com ações que visam obter a satisfação do cliente, empresas de SaaS podem alcançar melhores taxas de churn e continuar mantendo-se lucrativas. A satisfação é o elemento do marketing de relacionamento que, se colocado em prática, pode auxiliar empresas provedoras de SaaS a minimizar suas taxas de churn. 
Seybold (2002) defende que criar experiências positivas para o cliente pode ajudá-lo a sentir a sensação de satisfação. Escrever um post corporativo nas redes sociais relatando um sucesso desse cliente, enviar a ele um brinde criativo pelos correios ou um convite para um evento corporativo podem ser exemplos de ações que geram satisfação.

Gronroos (1990) aponta que aumentar a qualidade do serviço prestado também gera satisfação. Como já foi mencionado neste estudo, existe uma forte correlação entre qualidade e satisfação. É muito comum em empresas provedoras de $\operatorname{Sa} S$ S2B que, ao deixar o atendimento do vendedor do SaaS (executivo de contas) e passar a ser atendido pelo pós-venda (gerente de relacionamento) o cliente sinta uma diferença na qualidade do serviço. Se ele sentir uma melhora no serviço prestado a ele, se sentirá mais satisfeito; do contrário, começará a expressar sua insatisfação. É importante que as duas áreas comerciais da empresa, venda e pós-venda, estejam em constante comunicação e alinhamento, para que, no momento do handoff, quando o cliente é apresentado ao seu gerente de relacionamento, ele se sinta acolhido e bem atendido, superando suas expectativas.

De acordo com Pride e Ferrel (2001), um cliente insatisfeito tende a perder a confiança no relacionamento, o que o leva a procurar outro fornecedor. Para o autor, descobrir as principais expectativas do cliente e ser capaz de atendê-las leva à satisfação. Um bom momento para alinhar expectativas com um cliente de $S a a S$ é na seção de onboarding, geralmente o primeiro contato dele com o funcionário da empresa que passará a atendê-lo (gerente de relacionamento). Quando um bom onboarding é feito, o gerente de relacionamento já tem em mente o que o cliente tem como expectativa e qual será o plano de ação para atendê-la.

Ainda no onboarding de $S a a S$, é importante evitar fazer muitas promessas para os clientes naquele momento. É comum que a empresa queira, logo no princípio do relacionamento com o cliente, mostrar que é útil a ele e prometer algumas ações que talvez não possa cumprir no futuro. De acordo com Ndubisi (2007), a empresa precisa cumprir todas as promessas feitas ao cliente. Dessa maneira, não somente o satisfaz, mas também o retém e se assegura da receita oriunda de seu contrato em longo prazo. 
Outra boa prática é ter os gerentes de relacionamento, o ponto de contato do cliente no pós-venda, com um posicionamento focado nas necessidades do cliente e não apenas no upsell (adição de novos produtos ao contrato). De acordo com Beijou el al. (1998), para gerar satisfação, funcionários de venda devem ser focados nas necessidades do cliente e não apenas ter o interesse em vender para ele.

Mattar (2001) defende que é importante medir e identificar o nível de satisfação do cliente. Segundo o autor, a medição da satisfação pode ser feita de diferentes formas: uma delas é a pesquisa de marketing, na qual a empresa pode, por exemplo, perguntar aos seus clientes se eles preferem um produto específico ou algum outro.

\section{Qualidade do serviço prestado: Onboarding mal-executado}

O onboarding, que faz parte do serviço prestado ao cliente de muitas empresas provedoras de SaaS B2B, é apontado por vários autores como um passo muito importante no processo de venda e relacionamento com o cliente. Um onboarding mal-executado, no início do relacionamento, pode levar ao cancelamento do contrato por parte do cliente de SaaS mais adiante. A qualidade do serviço é o elemento do marketing de relacionamento que, se colocado em prática, pode auxiliar empresas de $\operatorname{SaaS}$ a reduzir suas taxas de churn.

Com a crescente competitividade do mercado, uma das estratégias encontradas pelas empresas foi oferecer serviço de alta qualidade para se destacar da concorrência (Parsuraman, Zeitham \& Berry, 1988). O investimento em um bom onboarding e na elevação de sua qualidade proporciona vários benefícios ao cliente e ao provedor de SaaS. Um serviço de qualidade, um dos elementos do marketing de relacionamento, resulta em clientes não somente satisfeitos, mas também leais (Berry, 1995).

Para Saliby (1997), é importante que as empresas entendam que os clientes estão cada vez mais exigentes e olhando bastante para qualidade, não somente para o preço. Para o autor, é preciso aproveitar todas as oportunidades para superar as expectativas dos clientes ao prestar 
um serviço. Uma boa maneira de superar a expectativa do cliente $B 2 B$ de $S a a S$ é justamente no onboarding, já que é o primeiro contato dele com o seu gerente de relacionamento e ele está geralmente ansioso para o começo do projeto e o uso da nova ferramenta. Um bom onboarding pode superar a expectativa do cliente e, desde o início, criar um relacionamento de confiança.

É válido, também, saber administrar as expectativas do cliente quanto à qualidade do serviço antes de começar o atendimento (Saliby, 1997). Em uma empresa de SaaS B2B, é importante que esse alinhamento ocorra ainda no momento pré-venda, no qual o cliente está sendo atendido pelo executivo de contas. Antes mesmo da compra, é indicado que o executivo comente que o cliente será atendido por um gerente de relacionamento e explique como será a apresentação a esse novo ponto de contato e como será seu onboarding. Dessa maneira, o cliente já é informado, antecipadamente, se terá um gerente de relacionamento virtual exclusivo, ou somente um portal de atenção ao cliente. Ele saberá, também, se seu onboarding será feito on-line, self-service, ou facilitado pelo seu próprio gerente de relacionamento.

Woo e Ennew (2004) acreditam que a qualidade do serviço prestado por uma empresa e a qualidade do relacionamento que estabelece com seus clientes determina a continuidade em longo prazo dos contratos entre compradores e vendedores. Em sua pesquisa, realizada em 2004, os autores defenderam a hipótese de que a qualidade do relacionamento entre vendedor e cliente no contexto $B 2 B$ tem um impacto positivo na percepção de qualidade do serviço prestado ao cliente. Ou seja, vendedores (ou gerentes de relacionamento) que têm um bom relacionamento com seus clientes, mais próximo e que os atendem, têm clientes mais satisfeitos com o serviço prestado e menos inclinados ao churn. O ideal é que esse relacionamento seja criado desde o primeiro dia de contato, ou seja, desde o onboarding.

De acordo com Lengnick-Hall (1996), contratar gerentes de relacionamento competentes, com bom comportamento e performance, causa um impacto significativo na maneira como os clientes enxergam a qualidade do serviço. Esses funcionários, de acordo com a autora, carregam uma grande responsabilidade quanto ao relacionamento: ele pode ser um sucesso ou 
um fracasso, dependendo de como for conduzido por eles. A maneira como um gerente de relacionamento conduz seu onboarding pode dar indicativos de como será o futuro da relação: alguns dedicam mais tempo a prepará-lo, para que seja customizado para o cliente; agendam mais tempo para conduzi-lo; o realizam através de videoconferência para que seja mais pessoal, ou seja, promovem uma experiência positiva para o cliente e, consequentemente, desenvolvem, a partir de então, uma relação de sucesso com ele.

\section{Falta de comunicação contínua com o cliente}

Quando uma empresa assina um software no modelo SaaS, significa que assinou um contrato, na maioria das vezes, curto (mensal, trimestral ou anual) e pode cancelar o uso da ferramenta a qualquer momento. Na literatura de $S a a S$, uma das razões mais comuns pela qual um cliente deixa um provedor é falta de uma interação contínua com ele. A comunicação contínua e personalizada é o elemento do marketing de relacionamento que, se colocado em prática, pode auxiliar empresas de SaaS a minimizar suas taxas de churn.

O marketing de relacionamento ressalta a importância da interação e comunicação contínua entre o cliente e a empresa, para manter um relacionamento de longo prazo (Morgan \& Hunt, 1994; Gronroos et al., 1994; Berry, 1983; Saliby, 1997). É muito comum em empresas de SaaS que o contato com o cliente seja feito apenas quando é conveniente ao seu gerente de relacionamento, ou seja, nos primeiros dias de contrato e nos dias que antecedem a renovação. Isso faz com que o cliente se sinta abandonado e acabe decidindo, muitas vezes, cancelar o contrato.

O cenário contrário, a intensidade na comunicação empresa-cliente, pode dar ao cliente a percepção de que ele possui para a empresa um status especial (Czepiel, 1990). Para facilitar a frequência de contatos, Berry (1995) menciona a tecnologia como uma forte aliada, já que possibilita canais de comunicação de duas vias: empresa-cliente e cliente-empresa. Chamar o cliente pelo nome durante as interações é também uma boa opção (Berry 1995). 
Uma boa prática do marketing de relacionamento é manter o mesmo gerente de relacionamento com o mesmo cliente (Berry, 1995). Isso ajuda na comunicação, (já que tanto um lado quanto o outro conhecem seu interlocutor), no relacionamento e na confiança estabelecida. Em um ambiente tão dinâmico como é o ambiente de tecnologia, em especial o do $\operatorname{Sa} S \mathrm{~S} 2 B$, o tempo de relacionamento pode ser decisivo para que, por exemplo, o cliente confie em uma sugestão de seu gerente de relacionamento para adicionar ao contrato um novo produto. Do contrário, quando já foi estabelecida uma relação de incompatibilidade e desconfiança, o melhor é a troca do gerente de relacionamento.

De acordo com Duncan e Moriarty (1998), a comunicação no marketing de relacionamento não deve envolver somente a persuasão do cliente, mas deve estar atenta a informar, escutar e responder. Para Ndubisi e Wah (2005), é parte do marketing de relacionamento manter o constante contato com o cliente, fornecendo informação sobre o serviço e avisando sobre qualquer mudança com antecedência, além de comunicar de maneira rápida e proativa, caso ocorra algum problema. O gerente de relacionamento, quando atuante no $\operatorname{Sa} a S B 2 B$, não deve apenas visar o upsell (adição de novos produtos ao contrato), mas também servir como um parceiro do cliente, sendo eficiente nas suas comunicações e se mantendo presente. Essas interações devem ser feitas de forma contínua ao longo de toda a relação, e não de maneira pontual ou desvinculada (Barreto, 2007).

Segundo Andersen (2001), no relacionamento contínuo entre empresas e clientes, websites e internet, de maneira geral, podem ajudar na frequência de comunicação e interação, tornando-se recursos importantes. Outra tática que ajuda na comunicação, segundo o autor, é a reunião presencial no escritório do cliente. A interação face to face é a mais benéfica, principalmente quando se dá no escritório do cliente, onde existe maior probabilidade de entender seus desafios (Andersen, 2001).

No setor de SaaS, dependendo do status do cliente, ele será abordado de maneira virtual ou presencial. Clientes maiores e com maior potencial, denominados high touch, recebem comunicações frequentes, de forma personalizada e, muitas vezes, as reuniões são feitas de 
forma presencial em seu escritório. Clientes considerados com menor potencial de crescimento, os low touch, recebem menos contato do seu gerente de relacionamento, que pode apenas direcioná-lo para a plataforma on-line de suporte ao cliente. Esses clientes não têm direito a visitas presenciais do seu gerente de relacionamento, e as videoconferências são, muitas vezes, substituídas por telefonemas ou e-mails, com o objetivo de atendê-los em escala.

Por fim, para que as expectativas estejam alinhadas desde o início do relacionamento, as empresas que desejam implementar uma estratégia de marketing de relacionamento devem buscar uma estratégia de comunicação com clientes: que canais serão usados e em que fase do processo (Andersen, 2001). Dessa maneira, desde o início, o cliente saberá com que frequência e de que maneira haverá comunicação.

\subsection{Considerações sobre a revisão teórica}

O SaaS, modelo de comercialização de software através da nuvem (cloud computing), ganhou força no mercado nas últimas duas décadas e mostra sinais de maior expansão nos próximos anos (Kienitz, 2018). Apesar do sucesso e de ter nascido na era digital, em que a tecnologia facilita a maior interação entre vendedores e compradores, enfrenta constantemente a ameaça do churn (Najjar et al., 2017; Yizhe et al., 2107).

Para que uma empresa provedora de SaaS seja lucrativa e obtenha sucesso, suas taxas de churn não podem ser mais altas que sua capacidade de adquirir novos clientes e aumentar os contratos com clientes existentes (Skok, 2016). O churn, maior desafio dessas empresas, não pode ser totalmente evitado, mas deve ser diminuído ao máximo, para manter a lucratividade da organização.

Em 1983, pela primeira vez na literatura do marketing, foi mencionado em um artigo científico o termo marketing de relacionamento. Para Berry (1983), solidificar as relações e transformar clientes indiferentes em leais deveria também ser considerado como função do marketing. A partir daí, o marketing de relacionamento se tornou um foco de estudo para 
vários pesquisadores, que começaram a investigar ações com o objetivo de fidelizar clientes, ou seja, evitar o churn.

Ao final da primeira parte desta dissertação, chamada de fundamentação teórica, o problema de pesquisa (churn em empresas de $S a a S$ ) e a possível solução (marketing de relacionamento) são retratados na tabela abaixo.

Tabela 2 - A aplicação do marketing de relacionamento para prevenção de churn em SaaS 
Clientes insatisfeitos com o serviço prestado

\begin{tabular}{|c|c|c|}
\hline Marketing de relacionamento (satisfação) & Autor & Ano \\
\hline Aumentar a qualidade do serviço prestado & Gronroos & 1990 \\
\hline $\begin{array}{l}\text { Gerentes de relacionamento devem ser focados nas necessidades do cliente } \\
\text { e não apenas ter o interesse em vender para o cliente. }\end{array}$ & Bejou et al. & 1998 \\
\hline Descobrir as principais expectativas do cliente e ser capaz de atendê-las & Pride e Ferrel & 2001 \\
\hline Criar experiências positivas & Seybold & 2002 \\
\hline Cumprir com as promessas feitas para o cliente & Ndubisi & 2007 \\
\hline \multicolumn{3}{|l|}{ Onboarding mal executado } \\
\hline Marketing de relacionamento (qualidade) & Autor & Ano \\
\hline $\begin{array}{l}\text { Contratar gerentes de relacionamento competentes, com bom } \\
\text { comportamento e performance. }\end{array}$ & Lengnick-Hall & 1996 \\
\hline $\begin{array}{l}\text { Administrar a expectativa do cliente quanto a qualidade do serviço antes do } \\
\text { início do relacionamento }\end{array}$ & Saliby & 1997 \\
\hline Superar a expectativa dos clientes quanto a qualidade do serviço prestado & Saliby & 1997 \\
\hline Oferecer serviço de alta qualidade & $\begin{array}{c}\text { Parasuraman, Zeithan, } \\
\text { Berry }\end{array}$ & 1998 \\
\hline Aumentar a qualidade do relacionamento entre vendedor e cliente & Woo e Ennew & 2004 \\
\hline
\end{tabular}

Falta de comunicação contínua com o cliente

\begin{tabular}{|c|c|c|}
\hline Marketing de relacionamento (comunicação contínua e personalização) & Autor & Ano \\
\hline $\begin{array}{l}\text { Não apenas desenvolver relacionamento com o cliente, mas manter a } \\
\text { comunicação e interação constantes }\end{array}$ & $\begin{array}{c}\text { Morgan, Hunt, Gronroos } \\
\text { et al., Berry, Saliby }\end{array}$ & $1983,94,97$ \\
\hline Intensificar a comunicação para que o cliente se sinta especial & Czepiel & 1990 \\
\hline $\begin{array}{l}\text { Usar a tecnologia como facilitadora, possibilitando canais de comunicação } \\
\text { de duas vias }\end{array}$ & Berry & 1995 \\
\hline Chamá-lo pelo nome durante as interações & Berry & 1995 \\
\hline Manter o mesmo gerente de relacionamento atendendo o mesmo cliente & Berry & 1995 \\
\hline $\begin{array}{l}\text { Comunicação não deve envolver somente a persuasão do cliente, mas deve } \\
\text { estar atenta em informar, escutar e responder }\end{array}$ & Duncan e Moriarty & 1998 \\
\hline $\begin{array}{l}\text { Fazer uso de recursos com a internet e visitas presenciais para facilitar a } \\
\text { comunicação com o cliente }\end{array}$ & Andersen & 2001 \\
\hline $\begin{array}{l}\text { Criar uma estratégia de comunicação com o cliente e definir que canais de } \\
\text { comunicação serão usados em cada fase do relacionamento. }\end{array}$ & Andersen & 2001 \\
\hline $\begin{array}{l}\text { Manter o constante contato com o cliente, fornecendo informação sobre o } \\
\text { serviço e avisando sobre qualquer mudança com antecedência, além de } \\
\text { comunicar de maneira rápida e proativa caso algum problema ocorra }\end{array}$ & Ndubisi & 2005 \\
\hline $\begin{array}{l}\text { Comunicação deve ser feita de forma contínua ao longo de toda relação, e } \\
\text { não de maneira pontual ou desvinculada }\end{array}$ & Barreto & 2007 \\
\hline
\end{tabular}

Fonte: desenvolvido pela autora.

Percebe-se que as principais causas de churn sofrido por empresas provedoras de SaaS podem ser endereçadas a ações de marketing de relacionamento encontradas na literatura, 
especificamente: satisfação, qualidade e comunicação contínua. A Tabela 2 foi construída com ações práticas, coletadas da literatura do marketing de relacionamento, em que os autores indicam a melhor maneira de seguir para atingir um único objetivo: a fidelização de clientes.

Com o objetivo de enriquecer a pesquisa e cumprir com seu objetivo, os próximos capítulos serão dedicados a uma pesquisa empírica em forma de estudo de caso, em uma empresa americana de $\operatorname{SaaS}$ com subsidiária no Brasil. No caso, será investigada a presença de ações de marketing de relacionamento desempenhadas pela empresa, seu impacto na retenção de clientes, e sugestões de modelos de relacionamento com o cliente em SaaS. 


\section{Pesquisa Empírica}

Este capítulo será destinado à pesquisa empírica, na forma de estudo de caso, na qual será estudada uma empresa americana de $S a a S$, com subsidiária no Brasil, que passou recentemente por uma mudança no seu modelo de relacionamento com clientes. A empresa, chamada neste trabalho de $A B C$ Software, decidiu segmentar sua base de clientes e atendê-los de duas maneiras distintas: relacionamento high touch, no qual existe um atendimento personalizado, consultivo e próximo a cada cliente, e relacionamento low touch, com atendimento massivo, em escala, no qual um gerente de relacionamento atende, ao mesmo tempo, um grande número de clientes.

No estudo de caso a seguir, serão identificados, em cada tipo de relacionamento desenhado pela $A B C$ Software (high touch e low touch), a presença ou não de ações de marketing de relacionamento desempenhadas pela empresa; a presença de alguma outra ação que tenha objetivo de retenção, mas não necessariamente seja de marketing de relacionamento; o impacto dessas ações na retenção de clientes em cada modelo, e sugestões oriundas do aprendizado da empresa, que já há três anos opera com o modelo high touch e low touch.

Destaca-se que essa proposta de pesquisa surgiu da experiência prática da pesquisadora, que acompanhou e participou ativamente do processo de mudança no modelo de relacionamento com o cliente da subsidiária.

\subsection{Classificação da Pesquisa}

Com o objetivo de embasar o trabalho de maneira sólida, a pesquisa foi classificada de três maneiras diferentes: quanto a seus objetivos, quanto à natureza de seus dados e quanto ao método de pesquisa. 
Segundo Gil (2002), o critério mais comum a ser utilizado ao se classificar uma pesquisa é tomando por base seu objetivo. Assim, é possível classificar as pesquisas em três grandes grupos: exploratórias, descritivas e explicativas.

As pesquisas exploratórias, ainda de acordo com Gil (2002), têm o objetivo de fazer com que o leitor sinta maior familiaridade com o problema. Ventura (2007) explica que, por sua flexibilidade, essa abordagem é recomendável nas fases iniciais de uma investigação sobre temas complexos, para a construção de hipóteses ou reformulação do problema. Além disso, é útil também na exploração de novos processos ou comportamentos.

$\mathrm{Na}$ maioria dos casos, as pesquisas exploratórias contêm levantamento bibliográfico, entrevistas com pessoas que fizeram parte do fenômeno estudado e análise de exemplos que facilitem a compreensão do leitor (Selltiz et al., 1976).

Diante disso, classifica-se esse trabalho como exploratório, uma vez que (a) aprofunda conhecimento sobre o marketing de relacionamento e suas aplicações no setor de software as a service (SaaS); (b) dá ao leitor abertura para a formulação de hipóteses, favorecendo futuras pesquisas sobre o tema; (c) entrevista funcionários de uma empresa do setor que participaram de um processo de adequação de modelos de atendimento ao cliente e, por fim, (d) estimula a compreensão do fenômeno estudado.

Quanto à natureza dos dados, trata-se de uma pesquisa qualitativa. Hair (2005) enfatiza que as abordagens qualitativas para coleta de dados são usadas tipicamente no estado exploratório do processo de pesquisa. $\mathrm{O}$ autor sugere ainda que, para os estudos exploratórios, a coleta seja feita através de entrevistas e observação do fenômeno estudado. Godoy (1995) acrescenta que a fonte dos dados de uma pesquisa qualitativa se encontra em seu ambiente natural e o pesquisador é o instrumento principal da investigação.

Finalmente, para escolher o método utilizado para o presente estudo, foi encontrada na seguinte frase de Gil (2008, p. 57), uma definição que se ajustou perfeitamente ao que se busca para esta pesquisa: “[...] o estudo de caso consiste no estudo profundo e exaustivo de 
um ou poucos objetos, de maneira que permita seu amplo e detalhado conhecimento". Gil (2008) aponta o estudo de caso como método mais utilizado em pesquisas exploratórias. De acordo com Vergara (1997), esse método tem o objetivo de estudar de maneira profunda e até mesmo exaustiva determinados objetos ou situações, permitindo um detalhamento que outros métodos não conseguem prover. Martins e Theóphilo (2007) destacam que se trata de uma investigação em profundidade dentro do contexto real do fenômeno, ou seja, o pesquisador não interfere ou controla o ambiente, e sua função é observar, inquirir e levantar dados que permitam compreender e interpretar um fenômeno.

Yin (2015) criou a tabela abaixo para ajudar pesquisadores a identificar qual método poderia ser utilizado para uma determinada pesquisa. Foi confirmado, aqui, que o estudo de caso seria o método mais viável para este trabalho, uma vez que, nesta pesquisa, a pesquisadora é uma observadora e não tem controle sobre nenhum evento durante o processo de investigação do fenômeno. Além disso, seu foco está em estudar um setor e um modelo de relacionamento recente e atual.

Tabela 03 - Identificando o método de pesquisa

\begin{tabular}{|c|c|c|c|}
\hline MÉTODO & $\begin{array}{l}\text { (1) } \\
\text { Forma de questào de pesquisa }\end{array}$ & $\begin{array}{l}\quad \text { (2) } \\
\text { Exige controle } \\
\text { dos eventos } \\
\text { comportamentais? }\end{array}$ & $\begin{array}{l}\qquad(3) \\
\text { Enfoca eventos } \\
\text { contemporâneos? }\end{array}$ \\
\hline Experimento & como, por quê? & Sim & Sim \\
\hline $\begin{array}{l}\text { Levantamento } \\
\text { (survey) }\end{array}$ & quem, o quê, onde, quantos, quanto? & Não & Sim \\
\hline $\begin{array}{l}\text { Análise de } \\
\text { arquivos }\end{array}$ & quem, o quê, onde, quantos, quanto? & Não & Sim/Năo \\
\hline Pesquisa histórica & como, por quê? & Nẵo & Não \\
\hline Estudo de caso & como, por quê? & Não & Sim \\
\hline
\end{tabular}

Fonte: Yin, (2015). 


\subsection{A Escolha do Caso}

Yin (2015, p.67) defende que o estudo de caso único é justificável sob certas condições "(..) nas quais o caso representa um teste crucial da teoria existente, nas quais o caso é um evento raro ou exclusivo ou nas quais o caso serve a um propósito revelador". Foi decidido, para esta pesquisa, utilizar o estudo de caso único, seguindo o fundamento lógico de ser um caso principalmente exclusivo, mas também raro.

A coleta de dados deste estudo de caso único, que teve como principal fonte entrevistas feitas com colaboradores de uma empresa de $S a a S$, foi conduzida exatamente no momento em que a empresa passava por uma transformação no seu modelo de atendimento ao cliente. A passagem se dava de um modelo majoritariamente high touch, no qual existe maior aproximação e customização do relacionamento com o cliente, para um modelo que também incluía o low touch, forma de atendimento escalável, self-service e com pouca interação humana.

Para atender ao objetivo da pesquisa, o estudo de caso único foi fundamental, uma vez que a pesquisadora, também observadora, pôde participar e estudar de perto um caso real e exclusivo, com o objetivo de fazer uma análise "generalizante" e não "particularizante" (Yin, 2015; apud Lipset, Trow \& Coleman, 1956, p. 419).

Da mesma maneira que Yin (2015) seleciona justificativas para a escolha de um estudo de caso único, foram selecionadas quatro justificativas para a escolha da empresa em questão como caso, aqui denominada $A B C$ Software:

1 - A empresa, subsidiária latino-americana de uma empresa americana de internet, comercializa, além de outros serviços/produtos, aplicativos de software B2B por meio do modelo SaaS (software as service), cenário no qual o fenômeno de relacionamento com o cliente será estudado. 
2 - A organização passou, recentemente, por um processo de introdução de um novo modelo de relacionamento com sua base de clientes, com o objetivo de aumentar a escalabilidade do atendimento, minimizar taxas de churn e aumentar taxas de upsell.

3 - A subsidiária, apesar de ter base no Brasil (São Paulo-SP), tem sua carteira de clientes espalhada por toda a América Latina, em especial, Brasil, México, Colômbia, Peru, Argentina e Chile. Esse fato pode ser importante para entender como o fator cultural pode impactar o relacionamento $B 2 B$ em SaaS.

4 - Houve facilidade de acesso à informação e possibilidade de observação do fenômeno por parte da pesquisadora, que trabalhou na empresa selecionada e participou ativamente da mudança no modelo de atendimento ao cliente.

Finalmente, a $A B C$ Software foi escolhida como caso para esta pesquisa, porque é um exemplo sólido de uma empresa provedora de SaaS que está em busca de encontrar a melhor maneira de se relacionar, satisfazer e manter seus clientes.

\subsection{Introdução ao estudo de caso}

Esta pesquisa será realizada em uma subsidiária americana do setor de internet, comercializadora de software no modelo SaaS (Software as a Service), e com base em São Paulo, Brasil. Apesar de estar fisicamente no Brasil, a empresa conta com uma equipe multicultural e clientes em toda América Latina, sendo que seus principais mercados são, nessa ordem: Brasil, México, Argentina, Chile, Colômbia e Peru. O escritório no Brasil tem, hoje, cerca de 350 funcionários, sendo a maioria deles focados em vendas e relacionamento com clientes.

Denominada, aqui, como ABC Software, para preservar sua identidade, a subsidiária possui quatro linhas de negócios e entrega a maioria de seus produtos e serviços seguindo o modelo SaaS. Em 2017, percebendo uma elevação nas suas taxas de cancelamento de contratos (churn), e seguindo a tendência mundial de escalar o relacionamento com pequenos e médios 
clientes (Small and Medium Business), a empresa colocou em prática um novo modelo de relacionamento com seus clientes existentes (low touch), sem descartar o modelo original (high touch).

O tipo de relacionamento com o cliente na $A B C$ Software passou a ser categorizado em dois grupos:

A) Relacionamento high touch: desenhado para clientes com maior potencial de crescimento $(L T V>5)$ e com tíquete médio de compra maior que USD10.000 de receita ao ano. Esses clientes possuem um gerente de relacionamento dedicado a eles e outros poucos clientes, visitando-os de maneira presencial, apresentando resultados e métricas trimestralmente, e são abordados com mais frequência de maneira personalizada.

Lifetime value, ou $L T V$, significa o potencial de crescimento de um cliente ao longo do contrato.

B) Relacionamento low touch: desenhado para clientes de menor potencial de crescimento ( $L T V 1$ a 4) e com tíquete médio de compra menor que USD10.000 de receita ao ano. Esses clientes possuem um gerente de relacionamento dedicado a vários outros clientes (cada um atende entre 100 a 200 clientes) e não recebem visitas de maneira presencial. Além disso, a comunicação se dá, na maioria das vezes, de maneira escalável e por e-mail. Os gerentes de relacionamento low touch contam com áreas de suporte, como centros de ajuda on-line, equipes de cobrança, equipes jurídicas e suporte de treinamento em massa.

Na Figura 6, abaixo, está o primeiro documento interno distribuído aos colaboradores da $A B C$ Software na América Latina, na versão em português, que explica as particularidades do projeto low touch e como o novo modelo de relacionamento deve ser apresentado aos clientes. A princípio, os idealizadores do projeto tinham a intenção de fazer com que o relacionamento se desse de maneira bastante escalável e self-service, nem mesmo mencionando a presença do 
gerente de relacionamento. Também por esse motivo, o termo gerente de relacionamento, no início do projeto, foi substituído por "equipe de suporte corporativo", para que os clientes entendessem, desde o princípio, que não existiria um atendimento individualizado.

Figura 6 - O início do Projeto Low Touch

\section{Projeto Low Touch Latam - (PT)。}

\section{Definição}

Modelo de atendimento em escala para clientes com perfis específicos.

\section{Características}

Contas con LTV = 1 a 4 + Deals < USD 10.000,00/ano.

\section{Pitch}

Você terá o apoio de uma Equipe de Suporte Corporativo, juntamente com conteúdo online, que te proporcionará:

- Respostas mais rápidas e assertivas, por meio de nosso centro de ajuda online;

- Suporte corporativo com resposta por e-mail, para dúvidas e informações sobre outras soluções;

- Centro de Treinamento Online com recursos como vídeos, tips e webinars, onde poderá encontrar tudo o que busca de maneira rápida e independente.

\section{Recursos}

- Centro de ajuda online + email de suporte (Icshelp-pt@cs.com);

- Centro de treinamento online;

- Email de boas vindas con instruções para iniciar o uso das soluções;

- Avisos automáticos de renovação de contrato.

Fonte: ABC Software (2017).

A coleta de dados secundários foi feita a partir da obtenção de informações e documentos relacionados aos modelos de relacionamento, bem como pelo acesso ao banco de dados de clientes da empresa. Já a coleta de dados primários utilizou a abordagem de pesquisa qualitativa, com a adoção de entrevistas em profundidade e a observação direta. Hair (2005, p. 152) destaca que "as abordagens qualitativas para coleta de dados são usadas tipicamente no 
estado exploratório do processo de pesquisa". O autor indica, para os estudos exploratórios, que a coleta seja obtida com dados narrativos por meio de entrevistas e observação de comportamento.

\subsection{Introdução às entrevistas}

De acordo com Yin (2015, p.27), o estudo de caso utiliza seis fontes distintas de informação para coletar dados: "[...] documentos, registros em arquivos, entrevistas, observação direta, observação participante e artefatos físicos”. De acordo com o autor, a entrevista é a fonte de informação mais importante para um estudo de caso.

Considerando os objetivos e a natureza desta pesquisa, foram utilizados os critérios descritos abaixo para a definição de uma amostra de entrevistados. Os 7 entrevistados selecionados da empresa $A B C$ Software foram divididos em três grupos:

Grupo 1) Gerentes de relacionamento high touch: nesse grupo, foram entrevistados três colaboradores da empresa (colaboradores A, B, e C) que atuam como gerentes de relacionamento high touch e estiveram na empresa entre 2017 e 2020, momento em que a subsidiária passou pela mudança no seu modelo de relacionamento.

Grupo 2) Gerentes de relacionamento low touch: nesse grupo, foram entrevistados três colaboradores da empresa (colaboradores D, E, e F) que atuam como gerentes de relacionamento low touch e estiveram na empresa entre 2017 e 2020, momento em que a subsidiária passou pela mudança no seu modelo de relacionamento.

Grupo 3) Além dos executivos de pós-venda, chamados de gerentes de relacionamento, foi entrevistada, também, a colaboradora $\mathrm{G}$, diretora de $S M B$ (pequenos e médios negócios) da $A B C$ Software para a América Latina e atual líder do projeto low touch dentro da empresa. 
A empresa $A B C$ Software não permitiu que seu próprio nome, assim como os nomes dos funcionários entrevistados, fossem divulgados. A tabela abaixo retrata de maneira visual o esquema de entrevistas.

Tabela 4 - Esquema de entrevistas

\begin{tabular}{|c|c|c|c|c|}
\hline \multicolumn{5}{|c|}{ Entrevistas High Touch } \\
\hline Entrevistado & Cargo & Relacionamento & Território & $\begin{array}{c}\text { Tempo na } \\
\text { empresa (anos) }\end{array}$ \\
\hline A & $\begin{array}{c}\text { Gerente de } \\
\text { Relacionamento }\end{array}$ & High Touch & Brasil & 4 \\
\hline B & $\begin{array}{c}\text { Gerente de } \\
\text { Relacionamento }\end{array}$ & High Touch & AR, CL, PE, CO & 5 \\
\hline $\mathrm{C}$ & $\begin{array}{c}\text { Gerente de } \\
\text { Relacionamento I }\end{array}$ & High Touch & Mexico & 4 \\
\hline \multicolumn{5}{|c|}{ Entrevistas Low Touch } \\
\hline Entrevistado & Cargo & Relacionamento & Território & $\begin{array}{c}\text { Tempo na } \\
\text { empresa (anos) }\end{array}$ \\
\hline $\mathrm{D}$ & $\begin{array}{c}\text { Gerente de } \\
\text { Relacionamento I }\end{array}$ & Low Touch & Brasil & 4 \\
\hline$E$ & $\begin{array}{c}\text { Gerente de } \\
\text { Relacionamento I }\end{array}$ & Low Touch & Mexico & 2 \\
\hline $\mathrm{F}$ & $\begin{array}{c}\text { Gerente de } \\
\text { Relacionamento I }\end{array}$ & Low Touch & $A R, C L, P E, C O$ & 2 \\
\hline \multicolumn{5}{|c|}{ Entrevista com a líder do projeto Low Touch } \\
\hline Entrevistado & Cargo & Relacionamento & Território & $\begin{array}{c}\text { Tempo na } \\
\text { empresa (anos) }\end{array}$ \\
\hline G & $\begin{array}{c}\text { Diretora de } S M B \\
\text { para Amética }\end{array}$ & Low Touch & Amétrica Larina & 1 \\
\hline
\end{tabular}

Fonte: desenvolvido pela autora. 
As entrevistas foram aplicadas e gravadas, com o consentimento dos entrevistados, no segundo semestre do ano de 2019. Foi estabelecido que todas as entrevistas seriam executadas de maneira presencial. O foco esteve em fazer perguntas amplas, que pudessem ser respondidas de maneira detalhada, para que os entrevistados contassem sobre sua experiência como atuantes dentro de cada tipo de modelo de relacionamento.

Quanto à coleta de dados, representada nesta pesquisa pelo roteiro de entrevistas, Yin (2015) indica que, para realizá-la de modo satisfatório, o pesquisador precisa ter procedimentos bem planejados. De acordo com o autor, os procedimentos de campo do protocolo devem focar em ter acesso à organização estudada e aos entrevistados; possuir recursos como um computador ou papel, além de um lugar calmo; pedir ajuda e orientação de outros colegas especialistas em estudo de caso; estabelecer uma agenda da atividade de coleta de dados para tê-la como guia. Além disso, o pesquisador deve estar sempre preparado para acontecimentos inesperados, como, por exemplo, mudança na disponibilidade de horário do entrevistado.

Ainda de acordo com Yin (2015), o protocolo pede um roteiro com um conjunto de questões substantivas que reflitam a investigação real. Por isso, a elaboração das perguntas do roteiro utilizado nesta pesquisa foi feita com base na seção 2.1.2, que discorre sobre elementos do marketing de relacionamento. $\mathrm{O}$ objetivo das perguntas do roteiro foi investigar como os elementos do marketing de relacionamento aparecem em cada modelo de atendimento (high touch e low touch) e identificar o impacto de cada um deles na retenção de clientes.

\subsection{Análise de dados}

Segundo Martins e Theófilo (2007, p. 69), “[a] análise de dados consiste em examinar, classificar e, muito frequentemente, categorizar os dados, opiniões e informações coletadas, ou seja, a partir das proposições, teoria preliminar e resultados encontrados, construir uma teoria que ajude a explicar o fenômeno". As análises devem ser realizadas com extremo cuidado para evitar resultados tendenciosos (Yin, 2015). 
Para Bardin (1997), “[a] análise de conteúdo aparece como um conjunto de técnicas de análise das comunicações, que utiliza procedimentos sistemáticos e objetivos de descrição do conteúdo das mensagens" (Bardin, 1977, p. 38). Ainda segundo a autora, esse conjunto de técnicas permite a análise da mensagem explícita e implícita do entrevistado, possibilitando que o pesquisador explore o conteúdo oral e, por meio da confirmação ou da inferência, verifique suas hipóteses.

Moraes (1999) defende que a análise de dados ajuda o pesquisador a interpretar e a compreender em profundidade os fenômenos estudados. Para que isso aconteça, o pesquisador precisa fazer uma leitura interpretativa dos dados coletados, em lugar de uma leitura comum.

Para Yin (2015), o primeiro passo seria possuir uma estratégia inicial, básica e generalista para analisar os dados, com o objetivo de desenvolver um bom senso sistemático do que vale a pena ser analisado e de como deveria ser analisado. O objetivo é ligar os dados do estudo com os conceitos de interesse, para que estes forneçam uma orientação para a análise dos dados. De acordo com o autor, isso ajuda a pôr em foco certos dados e ignorar outros.

Para esta pesquisa, será utilizado o protocolo de análise de dados de Yin (2015) e, por isso, a análise foi iniciada com a construção da sua estratégia base:

Figura 7- Estrutura para análise de dados

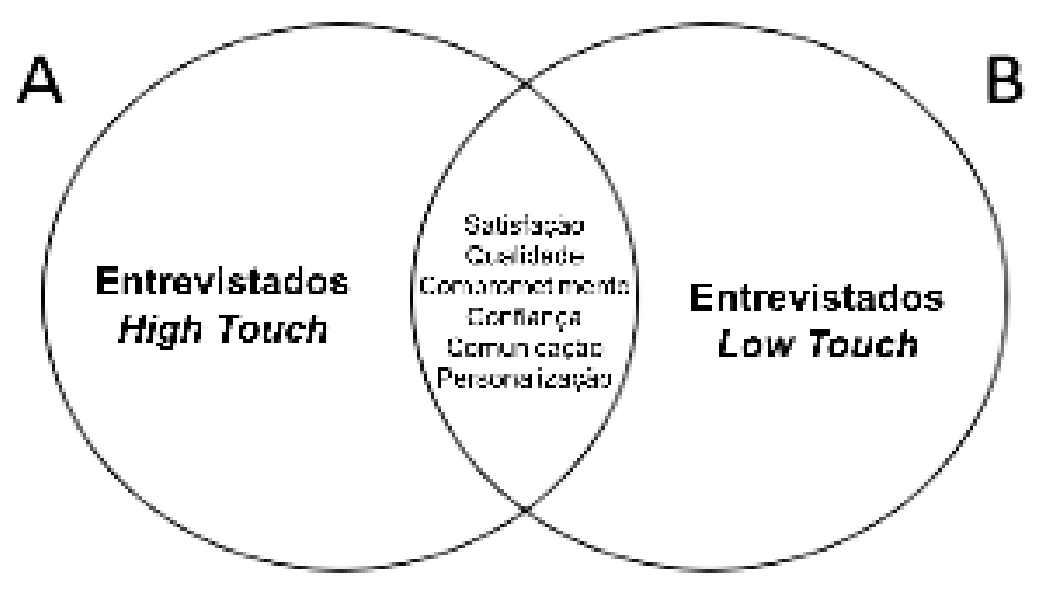


Fonte: desenvolvido pela autora.

Após o estabelecimento de uma estratégia geral, podem ser utilizadas várias estratégias analíticas específicas. Entre elas: adequação ao padrão, construção da explanação, análise de séries temporais e modelos lógicos de programa (Yin, 2015, p. 156). A técnica de análise utilizada nesta pesquisa será a construção da explanação, já que o objetivo é analisar os dados do estudo de caso, construindo uma explicação sobre a presença e o impacto do marketing de relacionamento nos diferentes modelos de relacionamento com o cliente de uma empresa de SaaS.

Para analisar os dados, as respostas de cada um dos entrevistados foram agrupadas por blocos, utilizando a ferramenta Google Sheets. Cada entrevistado ocupou uma aba da ferramenta, e cada bloco representou um elemento do marketing de relacionamento (satisfação, qualidade, comprometimento, confiança, comunicação e personalização). O conteúdo trazido por cada entrevistado foi analisado e comparado com as demais respostas, permitindo contrapor o resultado das entrevistas com a teoria estudada.

\subsection{Entrevistas com executivos high touch}

A empresa estudada, uma provedora de software $B 2 B$ no modelo SaaS, ou software como serviço, é uma subsidiária americana que chegou ao Brasil em 2012. A empresa será chamada, neste trabalho, de $A B C$ Software. De 2012 até o ano de 2017, a organização tinha apenas uma maneira de se relacionar com sua base existente de clientes: o modelo high touch, também conhecido como modelo tradicional. Com o tempo, passou, também, a adotar o modelo low touch, que será visto em detalhe na próxima seção.

No modelo de relacionamento high touch, existe um gerente de relacionamento dedicado a uma carteira de clientes, com o objetivo de atendê-los, criar relacionamento com esses clientes, visitá-los presencialmente, ser um consultor para eles e, preferencialmente, aumentar o valor dos seus contratos já existentes. 
No modelo high touch, ou tradicional, o gerente de relacionamento vai ter uma atenção pras contas muito maior, estando presente físicamente dentro dos clientes, onde a empresa espera que você como gerente de relacionamento possa aumentar o valor desses contratos, já que os clientes têm mais potencial e você tem mais proximidade com o cliente [Entrevistado A].

É o modelo tradicional de relacionamento com o cliente, onde um gerente de relacionamento sênior se dedica a uma carteira de clientes para atendê-los de maneira próxima e personalizada, com o objetivo principal de retenção. É o famoso consultor. É esperado dele que ele aprofunde o relacionamento com cada um dos seus clientes e consiga aumentar o valor dos seus contratos. O gerente de relacionamento desse modelo tem o objetivo de reter clientes e de fazer addons e upsells em sua carteira [Entrevistado C].

(...) o modelo que a empresa exige cada vez mais é focado não só na retenção, mas no upsell (na venda de produtos adicionais a um cliente existente). A empresa entende que a partir do momento que eu pago um executivo para estar dedicado para essa conta, este executivo tem que estar voltado a vender mais [Entrevistado B].

Foi bastante evidenciado pelos entrevistados que o objetivo do modelo e do gerente de relacionamento é a retenção do cliente, assim como se dá com as ações e elementos do marketing de relacionamento estudados nesta dissertação. As próximas perguntas direcionadas aos entrevistados buscaram identificar a presença dos elementos do marketing de relacionamento nos modelos de relacionamento (high touch e low touch) e seu impacto na retenção de clientes, ou seja, nas taxas de churn. Nesse sentido, a análise terá início pelo construto satisfação.

Nós não medimos a satisfação dos nossos clientes, não de maneira qualitativa. $\mathrm{O}$ que eu busco é sempre revisitar um por um dos meus clientes para saber se estão satisfeitos. Cada gerente de relacionamento faz da sua maneira, não existe uma regra. A empresa de maneira geral não mede satisfação. O papel da satisfação é crucial, se o cliente não tá satisfeito ele basicamente não vê valor. Tenho exemplos de clientes que precisavam da ferramenta, era claro que para a estratégia deles a ferramenta era essencial, mas não tinham visto valor por um atendimento anterior ou por um problema que havia acontecido que às vezes não era nem relacionado à ferramenta. A 
ausência da satisfação pode levar ao churn e mudança de fornecedor facilmente [Entrevistado B].

Ninguém mede satisfação na empresa hoje, não existe um NPS ou nada do tipo, mas deveria. Sinto falta disso. Temos que sentir de cliente por cliente o nível de satisfação. O gerente de relacionamento tradicional, o high touch, consegue fazer isso de forma mais fácil porque tem menos clientes. Eu garanto a comunicação constante com meu cliente, perguntando sempre se está tudo bem, se tem algo que podemos fazer para melhorar e me mantendo presente. Conhecer o cliente a fundo ajuda a entender o que de fato o satisfaz e pode-se agir em algo específico [Entrevistado C].

O Entrevistado A acredita que não dá para satisfazer todos os clientes e compartilhou uma estratégia para acessar o que seria satisfação para cada cliente:

Mesmo trabalhando em um modelo high touch, não se pode satisfazer todos os clientes. O que ajuda muito é priorizar por exemplo as top 10 contas e entrar a fundo em cada uma delas para realmente entender o que gera satisfação nesses clientes e que ações o gerente de relacionamento poderia fazer para garantir satisfação. Nem sempre o que achamos que gera satisfação, geralmente gera satisfação. Exemplo: existem clientes que não querem relacionamento. Para eles é suficiente se você o visita uma vez ao ano no momento da renovação. Dessa maneira ele está satisfeito [Entrevistado A].

De acordo com a literatura do marketing de relacionamento, a qualidade também é um elemento que ajuda no objetivo final das ações de marketing de relacionamento, que seria a fidelização de clientes. Foi perguntado aos entrevistados high touch da $A B C$ Software qual era a relação percebida por eles entre qualidade e a retenção de clientes, e quais ações eles praticam para garantir a qualidade no atendimento aos seus clientes nesse modelo. Os entrevistados A e B acreditam que alinhar as expectativas com o cliente em relação ao que será entregue, já no início do relacionamento, ajuda a entender o que, para o cliente, é percebido como qualidade, bem como a atuação nesse sentido para prevenção de churn. Para garantir um atendimento de qualidade a seus clientes, os entrevistados B e C acreditam ser importante se fazer presentes para o cliente e se aproximar dele, ir até o seu escritório, fazer um bom onboarding e servir como um consultor para ele. Para o Entrevistado B, assim como para vários autores do marketing de relacionamento, a qualidade está atrelada à satisfação: 
Eu alinho expectativas com o cliente desde o princípio do relacionamento, desde o primeiro dia. Não posso correr o risco de que ele esteja esperando que eu tenha apenas ele como cliente, sendo que eu tenho outros quarenta. Então conto para ele um pouco como eu trabalho, a frequência das nossas reuniões e como poderei ajudá-lo. A melhor forma de evitar churn é alinhar com o cliente como será seu atendimento desde o princípio do relacionamento. De preferência, desde o onboarding. Para garantir qualidade, eu me aproximo dele o máximo que posso e entendo o que gera nesse cliente satisfação, acho que as duas coisas estão ligadas [Entrevistado B].

Existe uma relação entre qualidade e fidelidade, com certeza. Um cliente que recebe qualidade vê valor no que foi comprado e tende a renovar, mas não é $100 \%$ das vezes que ele vai renovar o produto ou serviço. Qualidade não garante a fidelização do cliente, porque ela vai depender também de outros fatores. $\mathrm{O}$ que eu faço para garantir isso é estar presente no cliente para quando ele precisa, ir até o escritório visitá-lo, fazer um bom onboarding para ele, tirar suas dúvidas e ser uma consultora para ele [Entrevistado C].

Sim, com certeza qualidade está atrelada a churn, mas depende da percepção de qualidade de cada cliente. $\mathrm{O}$ cliente busca qualidade no serviço, no atendimento, no produto, onde? O que ele espera? Para entregar qualidade, o primeiro passo é perguntar para o cliente o que ele espera. Alinhar expectativas é o que, na verdade, previne churn [Entrevistado A].

Comprometimento é um outro elemento considerado importante no marketing de relacionamento. Foi perguntado aos entrevistados se algo era feito por eles para gerar comprometimento nos clientes, quais seriam os desafios nesse sentido e como o comprometimento poderia ser um aliado contra o churn. A resposta dos entrevistados divergiu nesse quesito, já que o Entrevistado A faz ações em prol de buscar compromisso por parte de seus clientes, como, por exemplo, reuniões de resultados trimestrais e ligações semanais; o Entrevistado B acredita que não se deve cobrar compromisso de clientes, pois isso deve ser algo natural, e o terceiro entrevistado, o Entrevistado C, acredita que o comprometimento por parte do cliente é oriundo da sua necessidade em relação ao uso do produto, cabendo a ele se comprometer com o uso da ferramenta/SaaS. 
Faço duas iniciativas: QBRs presenciais (quarter business reviews, ou reuniões trimestrais de análises de resultados e métricas), onde exige a participação do cliente e engajamento para análise de métricas. E também temos uma métrica, um KPI, de todo gerente de relacionamento, que é falar pelo menos uma vez ao mês com todos os clientes. (...) também fazemos eventos externos e convidamos o cliente, eventos internos para que conheçam nosso escritório, eventos de premiação, para premiar os que melhor usam nossa ferramenta. Acredito que essas ações ajudam a manter o cliente comprometido e fiel também à empresa [Entrevistado $\mathrm{A}$ ].

$\mathrm{Eu}$ não acho que se deve cobrar comprometimento do cliente. Devemos, como consultores, ser o exemplo e sempre nos mostrarmos comprometidos com o sucesso deles. Eu explico o meu trabalho, qual a estrutura com a qual eu trabalho, explico que sou uma gerente comprometida em ajudar com sua estratégia e seu sucesso, e que eu espero que ele esteja comigo nessa jornada. Dessa maneira, eu nunca tive que cobrar comprometimento. É algo que tem que ser alinhado desde o princípio e assim já evitamos o churn dali [Entrevistado B].

É difícil gerar comprometimento no cliente quando ele chega sem uma dor específica, quando perdemos um champion (ponto de contato principal e original no cliente), ou quando o cliente não tem fit para ser cliente da nossa empresa. É normal que muitos clientes percam o engajamento no meio do caminho e esses são os que mais têm risco de dar churn. O que eu faço para mitigar isso é me comunicar com meu cliente o máximo possível de maneira personalizada, mostrar para ele através das métricas que eu tenho o valor da minha ferramenta, o que eu posso agregar para ele e para o negócio dele, eu busco me reunir com ele presencialmente porque acho que ajuda. (...) mas, no fim das contas, o comprometimento é a parte que cabe somente a ele [Entrevistado C].

Ao abordar o elemento confiança nas entrevistas, os executivos high touch concordaram que, para ganhar a confiança dos clientes, é preciso se fazer presente e estar próximo, como um consultor que faz parte da equipe e não apenas está ocupando aquele lugar com o objetivo de vender mais produtos ao cliente. Para os entrevistados A, B e C, existe uma forte relação entre confiança e fidelidade. O Entrevistado $\mathrm{C}$ adicionou uma relação entre confiança e add-on, ou seja, a venda adicional de mais um produto no contrato existente do cliente. O Entrevistado A acredita ser mais fácil estabelecer relações de confiança com seus clientes quando tem com eles interações presenciais, ou face to face. Os entrevistados A e B demonstraram dificuldade em lidar com a pressão por parte da organização para que o gerente de relacionamento venda 
produtos adicionais no cliente sem, ao mesmo tempo, deixar transparecer que o seu objetivo é, também, aumentar o valor contrato.

Não deixar de ter contato, não deixar de estar presente, isso gera confiança. A confiança para mim e de acordo com minha experiência é o que gera fidelidade. Quando, você como gerente de relacionamento, tira a capa da empresa e vira um ser humano, assim como seu cliente, e se coloca à disposição para escutar e de verdade ajudar, é quando ele entende que tem uma pessoa ali que pode confiar, que não está ali apenas para empurrar coisas para você comprar, e nesse momento ele se fideliza e continuará com você por muito tempo. (...) eu prefiro comunicações face to face, porque acredito que ajudam na formação da confiança [Entrevistado A].

Eu sinto que meus clientes confiam em mim, é um feedback que eu recebo deles. (...) pelo menos $90 \%$ dos meus clientes confiam em mim e verbalizam isso. Creio que devo isso ao fato de gostar do relacionamento próximo com eles, independentemente do tamanho ou potencial do cliente, independente do que ele tem a me dar de volta. (...) Para mim, existe uma relação muito forte entre confiança e a renovação do contrato. Percebi que, às vezes, o cliente pode nem usar tanto a ferramenta, mas ele tem ali alguém que ele confia, que é para ele um trusted advisor, alguém que conhece muito do mercado e das tendências. (...) É um dilema eterno eu acho, de como se adequar, porque a empresa quer vender mais e você está dedicado, mas o cliente se ele te enxergar como vendedor, ele fecha a porta [Entrevistado B].

Para que você possa conquistar a confiança do cliente, você tem que ser construtivo. Agir como um consultor e não como um vendedor. Às vezes, mesmo que ele queira comprar com você uma solução, falar para ele que ele não precisa, caso de fato ele não necessita naquele momento. Dessa maneira, ele começa a confiar em você e no momento que você sugira que ele compre algo, ele vai acatar sua sugestão. Ser verdadeira com o cliente e fazer com que ele confie em mim me ajuda a evitar churn. Isso é muito difícil praticar, principalmente quando o gerente de relacionamento tem metas muito altas [Entrevistado C].

Por fim, os entrevistados responderam perguntas relacionadas a ações de comunicação e personalização, típicas do marketing de relacionamento, e como essas ações impactam suas taxas de churn. Os entrevistados A, B e C comentam que a comunicação com o cliente no modelo high touch é constante, sendo, inclusive, uma das métricas sobre as quais são 
cobrados. Além disso, foi unânime a percepção de que comunicação constante e personalização ajudam na prevenção do churn. O Entrevistado B se comunica de maneira personalizada com todos da sua base de clientes e acredita na importância da personalização para a retenção de clientes, mas sente que a empresa já não estimula esse comportamento, nem mesmo para os gerentes de relacionamento high touch. A razão por trás disso seria que, mesmo em uma carteira de clientes high touch, dentro de uma priorização de território, ainda existem os clientes que merecem mais atenção por darem resultados (receita) em curto prazo.

Eu me comunico frequentemente e de maneira personalizada com $100 \%$ dos meus clientes, mas percebo que não é algo que a empresa fomenta e sugere que façamos. Mesmo no modelo high touch, a empresa sugere que cada vez mais façamos ações escaláveis e foquemos cada vez mais nos $10 \%$ dos clientes premium, que seriam os key accounts, empresas que trariam mais resultado em curto prazo. Não concordo com isso, porque acredito que a personalização seja um fator importante para evitar churn. Como temos que reter $100 \%$ de clientes, continuo me comunicando de maneira personalizada com $100 \%$ deles [Entrevistado B].

A comunicação é sem dúvida constante, ligações e videoconferências constantes, a não ser que perceba que aquele cliente específico prefere não ser contatado. Os clientes também me acessam bastante e eu costumo ouvir muito atentamente, já que essas palavras irão me ajudar na fidelização desse cliente no futuro. Reuniões presenciais fazem parte da comunicação do modelo high touch e é muito bom ver a alegria do cliente quando vou visitá-lo, principalmente quando seu escritório fica em uma área mais remota e nunca nenhum outro gerente de relacionamento havia ido visitá-lo. (...) Eu acredito que visitas presenciais podem ajudar no estabelecimento de confiança e ajudar a evitar churn [Entrevistado A].

Mantenho uma comunicação constante com meu cliente e prezo muito por isso, inclusive somos medidos por isso, é um dos nossos KPIs. Temos que falar com o cliente pelo menos uma vez por mês. (...) A comunicação constante me ajuda a manter minha taxa de churn baixa. Hoje, está em $10 \%$ e quero chegar a $5 \%$. Acredito que não posso zerar meu churn, até porque sempre tem aquela venda que foi feita errada, país que entra em recessão, cliente que não estava preparado, empresa muito pequena que não tem dinheiro para pagar... [Entrevistado $\mathrm{C}$ ]. 
Um dos achados das entrevistas com os executivos high touch é uma ação comum praticada pelos três gerentes de relacionamento, que, segundo eles, ajuda na prevenção e combate ao churn, mas que não necessariamente é um elemento do marketing de relacionamento. Os três executivos high touch, mencionam o compartilhamento de dados (em forma de métricas, insights, análises) como um fator que ajuda na fidelização de clientes.

Sempre antes de falar de renovação eu faço um QBR com meu cliente [quarter business review], que é uma reunião onde eu apresento os resultados daquele cliente com a ferramenta traduzidos em dados, métricas, análises, comparação com competidores. (...) ali eu mostro o valor do meu produto e já me defendo de um possível cancelamento de contrato [Entrevistado A].

O mundo hoje não vive sem dados, insights, big data. Aqui temos sorte de fazer parte de uma empresa de software e nas nossas reuniões temos na mão para mostrar para o cliente o desempenho dele com a ferramenta SaaS que ele usa [Entrevistado B].

O que me ajuda muito a manter baixa a minha taxa de churn é levar métricas e dados para meus clientes, nos QBRs (quarter business reviews). Trazer muita informação pro cliente, informação do mercado, informação deles mesmos, trazer comparação com outras empresas, acho que isso ajuda a entender mais a fundo o cliente e mostra para ele insights que o ajudam a tomar decisões estratégicas. Ajuda muito falar que as empresas concorrentes estão fazendo certas ações que eles não estão fazendo e estão na frente deles [Entrevistado C].

Os entrevistados cederam os dois exemplos de informações que apresentam aos seus clientes nos QBRs (quarter business reviews), ou reuniões trimestrais de negócios, que, segundo eles mais os ajudam a provar o valor do produto e minimizar o churn. No primeiro exemplo (1), o gerente de relacionamento pôde mostrar ao cliente, de forma simples, o desempenho mensal da ferramenta $S a a S$ de recrutamento oferecida por ele. Além de quantas pessoas foram influenciadas pela solução, por mês, também é possível identificar a senioridade dessas pessoas e as funções que ocupam. 
Figura 8 - Exemplo de informações de um $Q B R$ (1)

\section{Your hires were influenced by your investment}

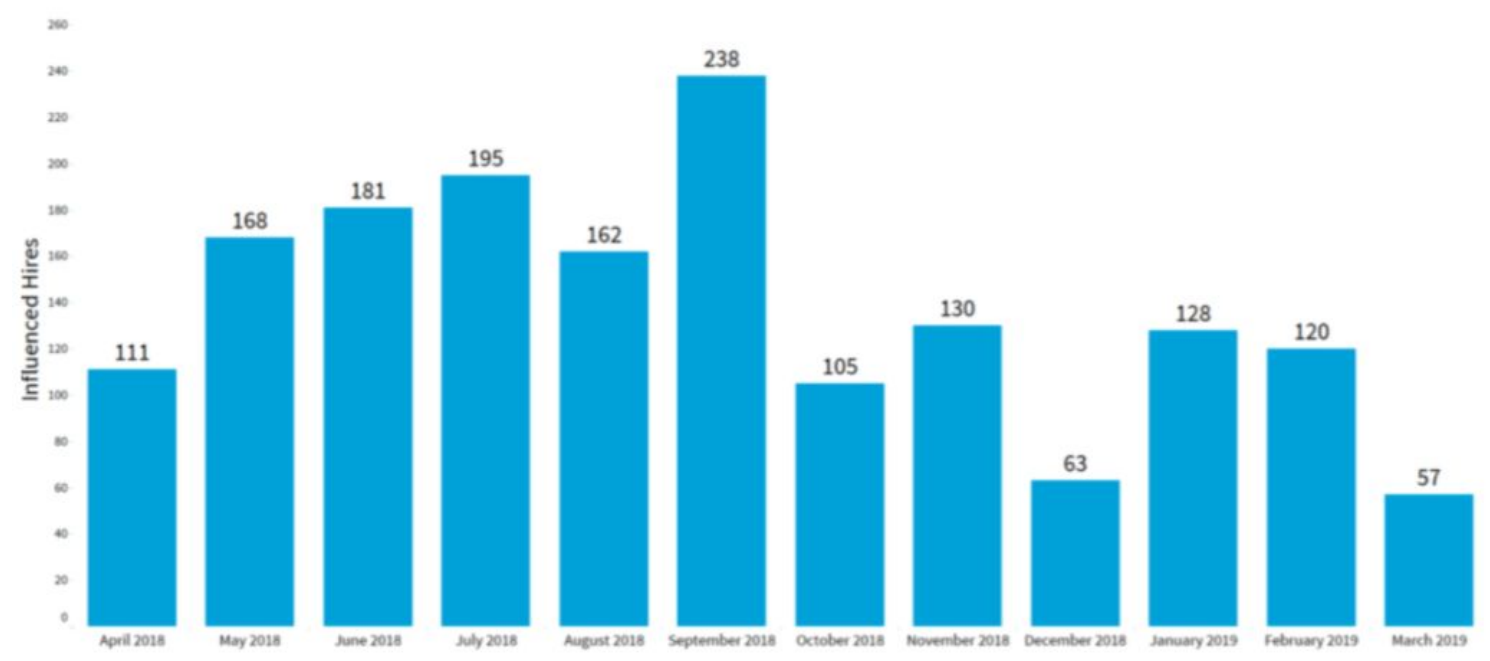

Top Seniority:

Top Job Functions:
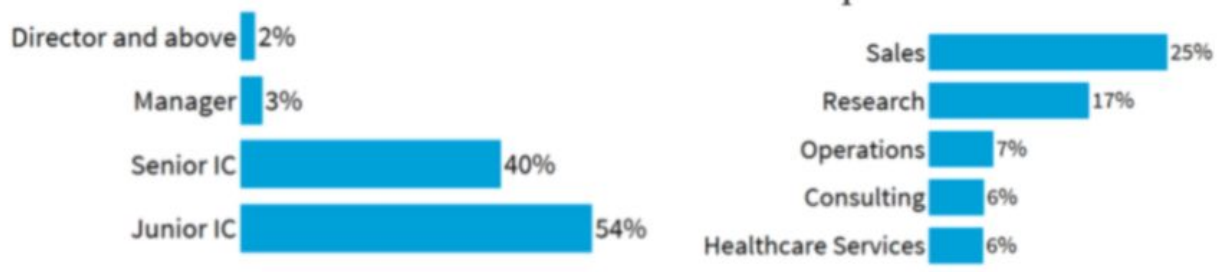

Fonte: ABC Software (2020).

No próximo exemplo concedido pelos entrevistados high touch, está a comparação de performance do seu cliente com seus principais concorrentes. Em azul, o cliente dado como exemplo conseguiu influenciar, graças ao uso do $S a a S, 58 \%$ dos candidatos abordados para que se candidatassem a uma vaga na empresa. Porém, existem outras empresas, também clientes da $A B C$ Software e grandes competidoras, fazendo um trabalho melhor. De acordo com o Entrevistado C, expor os concorrentes diretos do cliente e mostrar o seu sucesso chama a atenção do cliente, ajudando-o a tomar decisões estratégicas. Além disso, esse procedimento contribui para que os gerentes de relacionamento controlem suas taxas de churn. 
Figura 9 - Exemplo de informações de um $Q B R$ (2) Your peers are also influencing hires

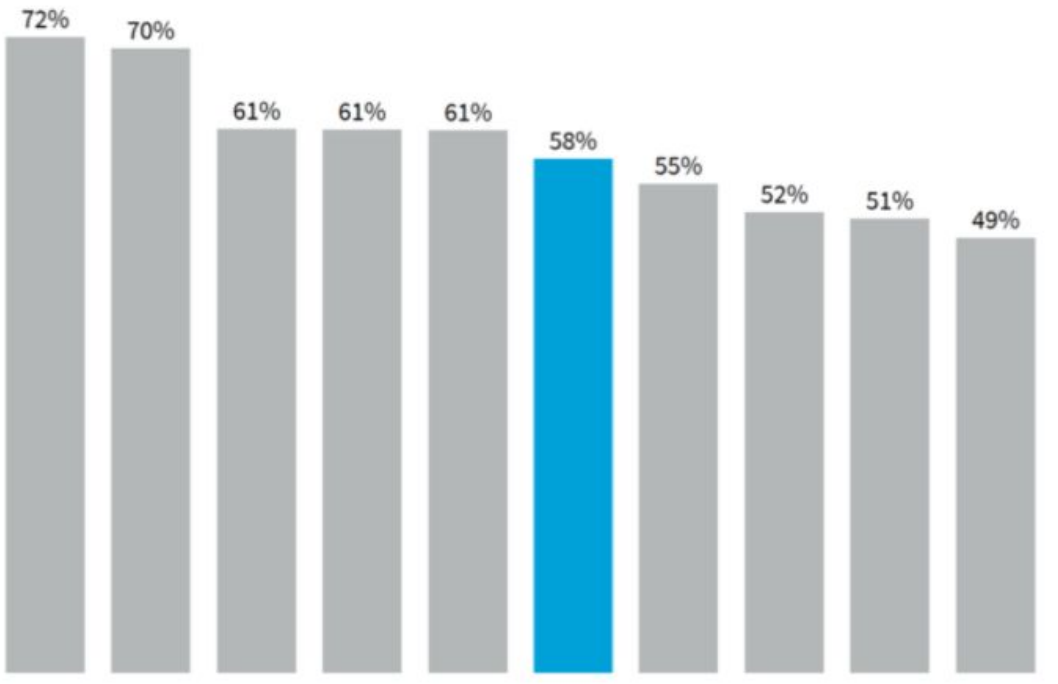

Peers: $\quad$ Amgen $•$ AstraZeneca $\bullet$ Bristol-Myers Squibb • GSK • IQVIA • Novartis • Novo Nordisk - Pfizer - Sanofi \begin{tabular}{|l|}
\hline You \\
\hline Peers \\
\hline
\end{tabular}

Fonte: $A B C$ Software (2020).

\subsection{Entrevistas com executivos low touch}

A empresa $A B C$ Software, até o ano de 2017, tinha apenas um modelo de relacionamento com sua base de clientes: o modelo tradicional ou high touch. Nesse modelo, os gerentes de relacionamento, responsáveis pelo suporte aos clientes de toda América Latina, atendiam desde clientes muito pequenos e de baixo potencial de compra, até grandes empresas, as maiores dos seus países. O tratamento era o mesmo para todos: visitas aos escritórios dos clientes para reuniões presenciais - o que implicava em viagens internacionais caras atendimento personalizado, apresentação trimestral de resultados, aprofundamento no problema específico de cada cliente, a fim de solucioná-lo, e o objetivo principal de não 
somente reter o cliente, mas também fazer upsell, ou aumentar o contrato existente com a venda de soluções adicionais.

Com o crescimento da empresa e o volume de novas contas que chegavam até a equipe de gerentes de relacionamento, esse modelo - sozinho - começou a tornar-se insustentável. Ao mesmo tempo, a matriz nos Estados Unidos já havia implantado adicionalmente um modelo de atendimento low touch, com o objetivo de solucionar esse problema e segmentar a base de clientes para que pudessem receber diferentes formas de atendimento, condizentes com as suas necessidades. A ideia não era dar aos clientes menores um atendimento ineficiente ou de baixa qualidade, mas apenas o que seria necessário a eles, já que a consultoria e proximidade do gerente de relacionamento era muito mais aproveitada por clientes de grande porte.

Outro grande objetivo do atendimento em escala aos clientes $S M B$ (pequenos e médios clientes), descrito pelos entrevistados como o principal, era diminuir as taxas de churn, ao mesmo tempo em que aplicavam redução de custos pela diminuição da operação (um gerente de relacionamento atendendo de 100 a 200 contas). O churn em contas SMB na ABC Software em 2017, como conta o Entrevistado A, chegava a 50\%.

O Entrevistado A, hoje gerente de relacionamento high touch, fez uma participação no início das entrevistas low touch, já que participou ativamente da implementação do projeto em 2017:

Os líderes da empresa começaram a perceber o aumento no número de clientes SMB, pequenas e médias empresas ou long tail, e que o retorno trazido por esses clientes era mínimo. Além de um baixo retorno, as taxas de churn eram muito altas (cerca de 50\%). O objetivo do modelo low touch é ter um gerente de relacionamento atendendo um número de clientes muito maior, 100 a 200 clientes, em escala. Esses clientes têm um LTV (life time value) inferior a 4 (em uma escala de 1 a 10) e tíquete médio de compra inferior a USD 10,000 ao ano. O objetivo é continuar dando ao cliente um atendimento de qualidade, porém a distância, com ações escaláveis. Para a empresa, o mais importante era controlar as taxas de churn [Entrevistado A]. 
O modelo de relacionamento low touch se mostrou eficaz nos Estados Unidos, mas foi preciso modificar alguns aspectos do que era feito lá, para que o projeto se acomodasse à realidade latino-americana.

Percebemos que nos Estados Unidos a sociedade estava muito mais preparada para o self-service, consequentemente para o low touch, o que não aconteceu aqui, principalmente em alguns países da América Latina [Entrevistado D].

A análise abaixo, cedida por um dos entrevistados, mostra o comportamento das primeiras 34 contas recebidas por um gerente de relacionamento low touch na América Latina, nesse caso, no Brasil. Fica evidente que o contato personalizado fez falta para os clientes nesse primeiro momento e muitos resistiram a seguir de uma maneira mais independente, ou self service. $60 \%$ dos clientes recém-adquiridos pela empresa que foram apresentados ao gerente de relacionamento precisaram de um contato personalizado (videoconferência ou ligação) para dar o primeiro passo rumo à utilização da ferramenta. $20 \%$ dos clientes atendidos pelo modelo low touch, ao saber que não existiria um treinamento individualizado para ele e sua equipe, insistiram em recebê-lo dessa maneira. Já $82 \%$ dos clientes que acabavam de assinar o contrato e chegar nas mãos do gerente de relacionamento low touch não completaram o primeiro treinamento on-line enviado.

\section{Figura 10 - O comportamento das primeiras contas low touch}

Contas Low Touch 2017:

Contas Low Touch recebidas em 2017: 34 (Média de RTA: USD7,000/ano \& LTV: 1-4)

- $60 \%$ dos clientes precisaram de uma vídeo conferencia ou ligação personalizada nos primeiros 20 dias de contrato, para poder dar o primeiro passo rumo ao engajamento;

- $20 \%$ dos clientes insistiram em um treinamento personalizado e individual, não convencidos de que o treinamento online seria suficiente;

- $82 \%$ dos clientes não completaram o primeiro training online enviado por email para dar início ao uso da ferramenta.

*Data collected from Aug-Nov 2017

Fonte: ABC Software (2017). 
A gente foi muito rígido no começo em relação às regras de não contactar o cliente, quase um no touch, que era como agiam nos Estados Unidos. Existe uma diferença forte nesse sentido, então quando a gente foi muito rígido, foi um ponto bem legal porque a gente percebeu que não funcionava e teve que se adaptar. Principalmente, porque estávamos no Brasil, numa cultura que precisa desse contato físico. Então é isso, a gente começou a perceber, "opa, então tá, deixa eu passar meu número de telefone”. No começo, a gente não passava número de telefone, mas depois percebemos que tudo bem, era mais para passar segurança pro cliente, os 100 não iriam ligar de uma vez. Porém, naquele momento, no dia 0, a gente não sabia. Não sabíamos de nada [Entrevistado A].

Entre os gerentes de relacionamento entrevistados, cada um trabalha com um mercado latino-americano: Brasil, México e América Central, América do Sul e região Andina. A entrevista começou com perguntas relacionadas à satisfação: se existem ações para medir a satisfação do cliente e o que eles, como gerentes de relacionamento, fazem para garantir satisfação. Os três entrevistados, D, E e F, relatam que, naquele momento, não era feita nenhuma ação por parte da empresa ou deles para medir satisfação, e que uma das razões pelas quais se fazia impossível a medição da satisfação de maneira qualitativa era a quantidade de clientes atendidos por cada gerente de relacionamento. Para os entrevistados E e F, um sinal de que o cliente não está satisfeito é quando comunica que não irá renovar o contrato com a empresa e, nesse momento, já é tarde demais.

Não medimos satisfação. É um gap que a gente tem. Eu tenho um contato tão distante com o cliente, que só vou saber se ele está satisfeito ou não um ano depois, no momento da renovação, e muitas vezes já é tarde demais. Quando ele renova me passa o sinal de que está satisfeito. Quando não renova, de que não está satisfeito. Durante o contrato, durante o ano, ele me dá alguns sinais de insatisfação, que é quando ele para de usar a ferramenta. Ali me sobe um alerta e eu tenho me aproximar dele. A medição da satisfação é muito mais qualitativa que quantitativa. De qualquer maneira, o modelo não quer que a gente busque necessariamente satisfação, porque não dá para satisfazer 170 clientes, nosso tratamento com eles é mais superficial [Entrevistado E].

A empresa não tem nenhuma ferramenta para medir e eu não meço, são muitos clientes. Eu só sei quando ele não está satisfeito porque quando ele se adianta e diz que não vai renovar o contrato dele. É algo 
que precisávamos fazer. (...) Eu gostaria de manter todos os clientes satisfeitos, mas como são muitos, atendemos 150-200 clientes cada, fica muito difícil, principalmente a distância. Sinto que muitos clientes são carentes, porque queriam ter mais atenção nossa e, por isso, se sentem insatisfeitos. Com a ferramenta acho que estão satisfeitos, mas não com o atendimento [Entrevistado F].

Como eu vou satisfazer um cliente que não conheço? Que não sei o que busca, quais são os objetivos, um cliente que é apenas mais um dos 200 clientes na minha carteira? Estamos mudando muita coisa no modelo low touch, começando pelo onboarding [Entrevistado D].

O Entrevistado D conta que, após dois anos do início do projeto low touch, estão sendo feitas algumas alterações no modelo para que, mesmo com ações em escala, possam garantir satisfação. O momento do onboarding, o primeiro contato entre o cliente e o gerente de relacionamento, foi escolhido para descobrir o que, naquele cliente, gera satisfação e quais ações posteriores podem ser feitas para a manutenção da satisfação.

Temos planos de implementar uma nova maneira de fazer onboarding no modelo low touch. Já estamos fazendo um piloto e os resultados são excepcionais. Percebemos que, mesmo de maneira escalável, é possível entender de cada cliente o que o deixaria satisfeito, através da criação da sua primeira meta com a ferramenta, através da exposição da sua dor, dos objetivos que precisa atingir. Assim, eu tenho em mãos o que ele precisa para atingir satisfação. Será implantado, ainda este trimestre, um survey para avaliar satisfação nos 30 primeiros dias do cliente, que acreditamos ser os mais importantes da sua jornada. Se estão satisfeitos com o início, provavelmente continuarão satisfeitos. Para garantir satisfação, também vamos fazer ações para celebrar o sucesso do cliente e enviar kits com brindes para o endereço do cliente quando ele cumprir sua primeira meta. Vamos também fazer eventos e coffee breaks no próprio escritório para chamar clientes para fazer networking e treinamentos [Entrevistado D].

Foi perguntado aos entrevistados low touch da $A B C$ Software qual a relação percebida por eles entre qualidade no serviço prestado pela empresa e retenção de clientes, e quais ações eles praticam para garantir a qualidade no atendimento aos seus clientes nesse modelo. $\mathrm{O}$ Entrevistado E menciona que, em algumas culturas, a qualidade do atendimento está relacionada à proximidade física do gerente de relacionamento, ou seja, à prática de reuniões e visitas presenciais. Como o modelo low touch não permite a locomoção do gerente de 
relacionamento até o cliente, o Entrevistado E acredita que a percepção da falta de qualidade resulta em churn. Já o Entrevistado D concorda que a cultura é um fator importante a ser considerado e que o brasileiro também espera proximidade nas relações de negócio. Mas, para ele, quando o cliente percebe valor no produto/solução oferecida e consegue solucionar seu problema com a ferramenta, se dá conta de que não necessariamente precisa de um gerente de relacionamento ao seu lado a todo momento.

É muito difícil entregar qualidade a distância na cultura que atendo, especialmente México. É uma cultura que pede muito a proximidade nos relacionamentos e isso eu não posso entregar para eles. Não posso visitar, fazer eventos, apertar a mão deles. Se o cliente não vir valor no que você entrega e não estiver comprometido, ele não confia em você. Isso leva a um cliente que não será fiel, ou seja, ao churn. Eu tenho um problema grave de churn, $40 \%$ ano. (...) acredito que os Mexicanos atrelem muito a qualidade do atendimento com a proximidade [Entrevistado E].

Depende do que seja qualidade para cada cliente. É muito importante que, na hora da venda, o $\mathrm{AE}$ (executivo de venda) não prometa muita coisa, tipo visitas presenciais, um executivo dedicado à conta dele, esse tipo de coisa. O cliente precisa, desde o início, entender ao que ele vai ter direito. Ele terá a mesma ferramenta de todas as empresas do mundo, mas não o mesmo atendimento. Ele será atendido em escala e precisa saber disso. Deixo isso bem claro desde o início. $\mathrm{O}$ que evita o churn não é a qualidade do que eu entrego como serviço ao meu cliente, mas o que ele percebe como qualidade e o que ele estava esperando receber. Se eu faço um call de onboarding, entendo suas dores, dou treinamento, acesso à ferramenta e, de vez em quando, mando e-mails para saber como ele está, e isso foi o combinado, pode ser para ele a tradução de qualidade [Entrevistado F].

Estar próximo do cliente é uma das maneiras de entregar um atendimento de qualidade e o cliente, na cultura do brasileiro, espera isso. Mas estar próximo nem sempre é necessário, o que é necessário é a percepção de valor que o cliente tem sobre o seu produto ou sua solução. Se ele percebe o valor, consegue solucionar o problema dele com o produto, ele fica tranquilo e não necessariamente precisa de um gerente de relacionamento ao lado dele todo tempo. "Eu consigo te entregar qualidade mesmo distante", é uma quebra de tabu no modelo low louch [Entrevistado D]. 
A próxima pergunta aos entrevistados foi direcionada a ações que gerem comprometimento no cliente e à importância do comprometimento para mitigar o churn. Os entrevistados E e F concordam em dois aspectos: a) o alto volume de clientes por gerente de relacionamento imposto pelo modelo low touch dificulta a criação de um ambiente que gere comprometimento ou ações que gerem comprometimento no cliente; b) se pudessem fazer visitas presenciais nos escritórios dos clientes e conhecê-los pessoalmente, poderiam gerar mais comprometimento por parte deles. Para o Entrevistado E, o projeto só terá sucesso e o cliente só renovará o contrato se estiver comprometido.

O comprometimento do cliente só acontece se, desde o início, o gerente de relacionamento se fizer presente, se mostrar estratégico pro cliente, se mostrar que está do lado dele, que ele é importante, e que o projeto só terá sucesso se ele estiver comprometido. De fato, o cliente só renova se estiver comprometido. É importante dar tarefas para ele, mostrar que sem ele o projeto não vai andar, mas que você estará lá para quando ele precisar. Se isso é feito no início fica mais fácil, mas como o volume que recebemos é muito alto, não conseguimos dar toda essa atenção a todos os clientes. Hoje, eu diria que $15 \%$ - 20\% dos meus 160 clientes são comprometidos. (...) o que eu poderia fazer para reverter isso seria ir até ele presencialmente, fazer um evento na cidade dele, despertar confiança nele, e o modelo não permite. (...) Existe um time frame logo no início do contrato que, se você não engajar o cliente ali, ele não se compromete mais. Seus e-mails passam a ser mais um. Nós mandamos muitos e-mails no onboarding e eles nem abrem os e-mails, porque não estão comprometidos desde o início. Depois que ele está desengajado, você pode fazer tudo, mas ele começa a falar: "nossa, olha esse cara chato me ligando de novo" [Entrevistado E].

O que sinto é que o comprometimento acontece muito com clientes que têm uma dor muito forte que a ferramenta consegue solucionar. Então, eles não têm escolha que não seja utilizar para solucionar seu problema. (...) eu não faço ações para gerar comprometimento, porque o volume de clientes é muito alto. O que posso dar e preciso dar a eles são as ferramentas para eles conseguirem usar o produto: o acesso, o treinamento, os materiais educacionais. Alguns são mais comprometidos e outros não. Se eu pudesse ir até o cliente, imagino que poderia gerar mais comprometimento, a distância é mais difícil, principalmente em alguns países [Entrevistado F]. 
Mais uma vez, o Entrevistado D, que está envolvido nas mudanças que estão sendo propostas para o modelo low touch, explica que, da maneira como o relacionamento é feito hoje, não existe um ambiente propício para a geração de comprometimento: nem por parte do gerente de relacionamento, nem por parte do cliente. Porém, mudanças estão sendo propostas nesse sentido, já que foi percebida a importância do comprometimento na busca pela retenção de clientes. É o segundo elemento do marketing de relacionamento que está sendo inserido no modelo low touch, curiosamente, através também do onboarding, assim como aconteceu com o elemento satisfação:

Fizemos alguns ajustes no modelo de onboarding dentro do projeto low touch para gerar comprometimento no cliente, isso está em teste para ser aplicado com todos. Antigamente, o onboarding era feito de forma totalmente massiva, com o envio de e-mails em massa mostrando como a ferramenta funcionava. Poucos clientes tinham uma interação (ligação, videochamada) personalizada, um para um. Percebemos que isso não funcionava, não gerava engajamento e perdíamos o cliente já dali. Não era o número de toques massivos no cliente que gerava comprometimento. Reestruturamos o onboarding e, partir de então, resolvemos que todos os clientes passariam a ter uma videochamada de 30 minutos com o gerente de relacionamento, onde ele diria ali qual seu principal desafio e sua principal meta. Juntos, o gerente de relacionamento e o cliente traçam uma primeira meta, chamada primeiro sucesso do cliente, e um plano para alcançá-la. Esse simples passo gera comprometimento no cliente. A partir daí, o gerente de relacionamento dá ao cliente todo o material necessário para ele cumprir seu objetivo. No onboarding antigo, jogávamos as informações para o cliente para ele ver valor naquilo e achar seu sucesso ali. No novo onboarding, nós colocamos o sucesso dele na mão dele e pedimos seu comprometimento. É o cliente que agenda a primeira videoconferência com o gerente de relacionamento, é o cliente que traça sua meta e compromisso, é o cliente que vai ter o primeiro sucesso com o uso da ferramenta. Pedir o compromisso dele funciona para dar uma vida longa ao relacionamento [Entrevistado D].

Os entrevistados contam que o volume alto de clientes que atendem e a distância imposta pelo modelo low touch, já que não podem visitar os clientes presencialmente, são os fatores que mais impedem a formação da confiança. O fator cultural, muitas vezes citado durante as entrevistas, têm um papel importante na formação da confiança entre empresa e cliente, como relata o Entrevistado F: 
Existem duas coisas que me impedem hoje de construir confiança com meus clientes. $\mathrm{O}$ volume de clientes, 150-200 clientes na minha mão, e a distância. Na América Latina, principalmente em países como México, Colômbia e Peru, é difícil construir relacionamentos sólidos apenas de maneira on-line, sem nunca ter a oportunidade de ver $o$ cliente. Já na Argentina e no Brasil é um pouco mais fácil. Ter um contrato de USD 5.000/ano e passar a um contrato de USD 100.000/ano não é impossível, mas é muito difícil quando não existem interações presenciais. O que eu ainda posso fazer para ganhar a confiança dele é me manter sempre presente, responder os e-mails muito rápido, eles geralmente apreciam muito uma rápida resposta. $\mathrm{E}$ também quando consigo resolver um problema para eles, como um problema de pagamento, por exemplo, percebo que eles começam a confiar mais em mim [Entrevistado F].

Acredito que a geração de confiança, de ambas as partes, cliente-gerente de relacionamento e gerente de relacionamento-cliente, se dá de maneira bem mais fácil em um modelo de relacionamento que permite as interações pessoais, ao vivo, reuniões e encontros presenciais, o que não é o caso do projeto smart touch, onde todos os contatos são feitos on-line. Eu acredito que criar laços ao vivo é bem mais fácil e criar laços envolve talvez confiar na pessoa. Esses laços não necessariamente serão comerciais e profissionais, eles podem começar a se tornar pessoais, e tudo isso ajuda no processo de confiança. Ao mesmo tempo, acredito que destruir confiança é tão fácil para um gerente de relacionamento high touch quanto para um gerente de relacionamento low touch. Não se trata apenas de construir, mas garantir que isso não vá ser destruído em nenhum momento [Entrevistado D].

O Entrevistado D explica, abaixo, que algumas mudanças relacionadas ao ganho de confiança do cliente também estão sendo pensadas para o projeto low touch, para garantir um relacionamento de longo prazo.

O que a gente está pensando em fazer do nosso lado é tentar blindar esse relacionamento de qualquer forma, entendendo o que é o valor para o cliente, entendendo qual é o tipo de necessidade que ele tem, como que é o dia a dia da pessoa, o que dói nela, perguntando se está tudo bem de tempos em tempos, estabelecendo metas. (...) tudo isso no onboarding, no primeiro contato. (...) porque eu preciso que o cliente realmente confie em mim no sentido de que eu quero ajudá-lo a alcançar algo, mesmo a distância, mesmo sem estar ao lado dele fisicamente [Entrevistado D]. 
Os entrevistados também responderam perguntas relacionadas a ações de comunicação e personalização, típicas do marketing de relacionamento. Foi perguntado a eles como eram feitas as comunicações com os clientes, se eram frequentes e personalizadas. Os entrevistados E e F relatam que a comunicação é feita quase sempre de maneira "massiva" e não personalizada, devido ao grande número de clientes que possuem. Uma prática comum, também entre os dois entrevistados, é planejar o território e selecionar algumas poucas contas com maior potencial para manter um contato mais personalizado. O objetivo, nesse caso, é tentar se aproximar desses clientes com o objetivo de upsell, ou seja, vender mais produtos no contrato existente. Quanto à frequência da comunicação, os entrevistados E e F compartilham que, mais uma vez devido ao alto volume de clientes, não existe uma comunicação contínua entre as duas partes:

O volume de clientes é tão alto nesse modelo low touch, que é preciso fazer um bom planejamento de território e depois que dividir as contas em blocos, tentar personalizar os contatos. Não tenho como personalizar todos, então separo minhas melhores contas, $10 \%$ da minha carteira, para tratá-las de maneira especial, e conseguir crescer seus contratos. Os outros $90 \%$ recebem a mesma comunicação massiva por e-mail. (...) os clientes geralmente respondem meus e-mails nos primeiros três meses, mas depois param mais de responder. Eu não sei se é porque eles já estão indo bem e não precisam mais de mim, ou porque estão desengajados e estou começando a perder eles [Entrevistado E].

A comunicação com o cliente não é frequente. Eu faço uma ligação rápida no início do relacionamento, telefone mesmo, assim que o cliente se torna cliente da empresa, e a partir daí fica muito mais na interação por e-mail. Eu já deixo isso alinhado no nosso primeiro contato, que eu trabalho com muitos clientes e que não posso estar buscando ele a todo momento, mas ele pode me escrever por e-mail sempre que quiser que eu vou responder. Alinho bem as expectativas no início. A comunicação é quase sempre massiva com toda a base de clientes, só mudo o nome. Para alguns clientes, que vejo que têm mais potencial, eu personalizo com a esperança de aumentar o contrato e fazer upsell naqueles clientes [Entrevistado F]. 
Foi feita a mesma pergunta para o Entrevistado D, que está envolvido na elaboração das mudanças que, em breve, serão implementadas no projeto low touch, e que, segundo ele, são mudanças "pensadas de acordo com todo o aprendizado que vivemos no decorrer desses anos com o projeto e que vemos que são necessárias para ter sucesso com ele [o modelo low touch] na região" [Entrevistado D]. Com todo o aprendizado acumulado ao longo de dois anos de projeto, não somente foi percebida uma urgência em medir satisfação, gerar comprometimento e confiança nos clientes, como foi relatado nas entrevistas acima, mas também foi percebido pelo grupo uma urgência em mudar a maneira em como é feita a comunicação com o cliente e sua frequência:

Percebemos que a comunicação tem que ser mais frequente no início do projeto. Isso ajuda a evitar o churn lá na frente. Não só frequente, mas também personalizada. Todos os clientes, assim que fecham contrato, têm uma video call com o gerente de relacionamento, um para um, para que possam se conhecer melhor e definir seu plano de ação. A importância da comunicação personalizada no início do relacionamento é que, quando você se mostra interessado no cliente e faz perguntas sobre ele, sobre o dia a dia dele, sobre os desafios dele, ele se abre para você e fala sobre as suas dores. Ter as dores do cliente, mesmo que somente naquele primeiro call, te ajuda a te guiar durante o ano todo. (...) depois de um tempo, a ideia é trabalhar em escala mesmo, já não existe o personalizado, até porque não dá mais, o volume é muito grande [Entrevistado D].

Com o objetivo de investigar com mais profundidade a transformação pela qual passou o modelo de relacionamento low touch, desta vez, com uma visão mais macro e estratégica do negócio, a entrevista a seguir se deu com a diretora para $S M B$ para América Latina da $A B C$ Software, Entrevistada G.

\subsection{Entrevista com a líder do projeto Low Touch}

Do segundo semestre de 2017 ao segundo semestre de 2019, momento da execução das entrevistas desta pesquisa, a empresa $A B C$ Software colocava em prática o projeto low touch, modelo de atendimento ao cliente que tem por objetivo melhorar as taxas de churn do 
segmento $S M B$, reduzir custos e dar a cada cliente um atendimento adequado à sua demanda, por meio do atendimento em escala.

Ao assumir o departamento $S M B$ e começar a gerenciar a equipe de gerentes de relacionamento low touch, no início de 2019, a Entrevistada G encontrou o seguinte cenário:

Antigamente, o objetivo era juntar todas as contas de pouco potencial para serem atendidas em escala. Não se dava vontade de pegar esse desafio, já que a expectativa de churn era muito alta e o que era esperado era que os gerentes de relacionamento do modelo low touch fossem apenas reativos. Se as contas não vão crescer, por que investir nelas? O projeto acabava ficando limitado [Entrevistada G].

Foi preciso, de acordo com a entrevistada, uma mudança de mindset, para que a empresa como um todo começasse a encarar o trabalho que estava sendo feito de uma maneira diferente. A partir daí, o objetivo passou a ser não somente a retenção de clientes e a minimização de churn, mas também o crescimento dos contratos dos clientes.

a grande mudança foi: a gente precisa entregar sucesso para os pequenos negócios na América Latina. Então esse foi o primeiro passo: a mudança de mindset. Isso está neste momento em construção para todos: o que o departamento de low touch vai fazer, qual o seu objetivo, qual é o ICP [perfil do cliente ideal] do projeto. Nós podemos crescer essas contas, sim [Entrevistada G].

A próxima pergunta foi direcionada a entender exatamente o que estava sendo mudado no modelo low touch, desde que o projeto começou, em 2017, e quais serão as ações colocadas em prática a partir de agora.

A gente quer um processo desenhado para entregar de forma organizada, planejada e orquestrada a melhor experiência possível para esse cliente, para que ele cresça sim, para que ele consiga expandir sim. (...) Eles terão uma jornada clara do que que eles vão receber: do marco zero até o terceiro mês. E isso, consequentemente, nos meses seguintes: treinamentos, eventos, e-mails, webinars, etc. Eles também vão receber QBR's personalizados trimestralmente. Existe uma sequência a ser seguida: ele recebe um goal setting, faz um planejamento. Tem um onboarding de trinta dias, surveys. (...) A 
gente coloca a partir de agora uma nota de satisfação em relação ao que é entregue. A gente está buscando uma meta de fazer com que o maior número possível de clientes novos que passa por onboarding dê pelo menos uma nota de oito, NPS mesmo, após 30 dias de contrato. É uma nota mínima em relação à satisfação com o que foi entregue pelo serviço, ou seja, pelo atendimento do gerente de relacionamento, e também satisfação em relação ao produto [Entrevistada G].

Os objetivos das mudanças propostas, de acordo com a entrevistada, são reduzir as taxas de churn do modelo low touch e chegar ao mesmo número do time de gerentes de relacionamento high touch, provando que não existem muitas diferenças nos dois modelos. A única diferença, segundo ela, é que os gerentes de relacionamento high touch visitam seus clientes de maneira presencial, enquanto os gerentes low touch não têm contato físico com seus clientes.

Eu espero com esse novo projeto reduzir 10\% do churn até o final do ano que vem [final de 2020] e então chegar na casa dos $20 \%$, que leva o nosso time praticamente ao mesmo do modelo tradicional [high touch]. E aí vem um grande pulo do gato que é: eu quero provar que o nosso modelo de atendimento, a única diferença do modelo tradicional, é que tradicional visita o cliente, e eu não (...) Vai acontecer e a gente vai deixar claro que no nosso modelo é um modelo mais produtivo, escalável e que entrega resultado [Entrevistada $\mathrm{G}$ ].

Apesar do otimismo, a entrevistada alerta para o grande desafio do relacionamento com clientes no segmento de $S M B$, em que o churn é uma característica marcante.

SMB é o segmento que mais vai abrir oportunidade e vai fazer com que a empresa expanda, é um projeto muito legal, na verdade, mas o mercado é muito difícil, então o churn alto é característico de SMB. Um churn esperado de $30 \%$ a $50 \%$, isso já é mercado, não é uma característica nossa. Isso é mercado. São contas mais difíceis mesmo [Entrevistada G].

Por fim, a entrevistada alerta para o fato de que o problema de retenção de clientes e altas taxas de churn começa, muitas vezes, no departamento de marketing, quando a organização precisa identificar quem é o cliente ideal para a empresa, ou ICP (ideal customer profile). De acordo com a Entrevistada G, não adianta ter uma máquina de retenção de clientes preparada, se a máquina de aquisição não está trazendo clientes que têm fit com a empresa: 
A gente tem um balde muito furado. Eu tô escrachando para a organização que hoje eu tenho um time de aquisição focado em fazer né, aquisição de contas, colocando hora de pessoas, esforço de pessoas, para trazer contas que não se pagam. Então o processo de evitar o churn, ele começa lá no marketing, entendendo quem eu tô atraindo (...) eu tô colocando uma máquina de aquisição, e muitos clientes saem em um ano. É muito óbvio que essa balança está totalmente desequilibrada [Entrevistada G].

No capítulo a seguir, será feita a análise do estudo de caso. O conteúdo das entrevistas, as informações sobre a empresa e os documentos coletados foram agrupados e analisados, permitindo justapor seu conteúdo à teoria estudada.

\section{Análise do estudo de caso}

A análise do estudo de caso desta pesquisa será dividida em quatro partes:

- Como é aplicado o marketing de relacionamento nos diferentes modelos de relacionamento com o cliente (high touch e low touch) da $A B C$ Software e seu impacto na retenção de clientes (Tabela 5);

- Quais foram os aprendizados adquiridos pela $A B C$ Software com a implementação do modelo low touch na América Latina e sua relação direta com ações de marketing de relacionamento (Figura 11);

- Qual é a importância do onboarding na fidelização de clientes e qual modelo será seguido pela empresa (Figura 12), e

- O que está sendo proposto pela liderança do projeto low touch para minimizar as taxas de churn do modelo e o papel do marketing de relacionamento na formatação do novo plano de ação (Tabela 6). 
Os modelos de atendimento ao cliente adotados pela $A B C$ Software (high touch e low touch) possuem características bastante distintas, como foi possível observar nas entrevistas conduzidas no estudo de caso. Os modelos também diferem na adoção de ações de marketing de relacionamento praticadas por seus gerentes de relacionamento.

Enquanto os gerentes de relacionamento high touch listam vários exemplos de ações de marketing de relacionamento que ajudam na retenção de clientes (garantindo satisfação, estabelecendo confiança, entre outros), os gerentes de relacionamento low touch indicam o alto volume de clientes (100 a 200 clientes por gerente de relacionamento) e a distância imposta pelo modelo (não poder visitar seus clientes presencialmente) como os dois principais fatores que os impedem de agir em prol da retenção de seus clientes.

Na tabela 5, a seguir, são apresentados os exemplos de ações de retenção feitas por executivos high touch, dentro de cada elemento do marketing de relacionamento, e as razões pelas quais se torna difícil, para os executivos low touch, executar ações em prol da retenção de clientes: 
Tabela 5 - O marketing de relacionamento nos modelos high touch e low touch

\begin{tabular}{|c|c|c|}
\hline \multirow[b]{2}{*}{$\begin{array}{l}\text { Marketing de } \\
\text { relacionamento }\end{array}$} & \multicolumn{2}{|c|}{ Entrevistas } \\
\hline & Low Touch & High Touch \\
\hline Satisfação & $\begin{array}{l}\text { O volume de clientes atendidos e a distância } \\
\text { física imposta pelo modelo, dificultam ações } \\
\text { que proporcionem satisfação. Somente no } \\
\text { momento da renovação ou não do contrato, o } \\
\text { gerente de relacionamento percebe a } \\
\text { satisfação ou insatisfação do cliente. }\end{array}$ & $\begin{array}{l}\text { Revisitar um por um dos clientes para saber se } \\
\text { estão satisfeitos; garantir a comunicação } \\
\text { constante, sempre perguntar se está tudo bem; } \\
\text { tentar conhecer o cliente a fundo e entender o } \\
\text { que o satisfaz; Entender o que é satisfação para } \\
\text { cada cliente; se manter presente. }\end{array}$ \\
\hline Qualidade & $\begin{array}{l}\text { Alinhar expectativas do serviço que será } \\
\text { oferecido desde o primeiro dia; combinar } \\
\text { com o cliente que não haverá reunião } \\
\text { presencial ou nada personalizado, mas que } \\
\text { ele terá a mesma ferramenta que todos os } \\
\text { clientes têm; mostrar o valor da ferramenta } \\
\text { para o cliente e que ele veja valor nisso, e } \\
\text { não necessariamente no atendimento. }\end{array}$ & $\begin{array}{l}\text { Alinhar expectativas do serviço que será } \\
\text { oferecido desde o primeiro dia; se aproximar } \\
\text { do cliente; entender o que é satisfação para } \\
\text { cada cliente; visitar o cliente presencialmente; } \\
\text { fazer um bom onboarding; tirar dúvidas; agir } \\
\text { como um consultor; perguntar ao cliente o que } \\
\text { ele espera de mim. }\end{array}$ \\
\hline Comprometimento & $\begin{array}{l}\text { O alto volume de clientes por gerente de } \\
\text { relacionamento imposto pelo modelo low } \\
\text { touch, dificulta a criação de um ambiente que } \\
\text { gere comprometimento ou ações que gerem } \\
\text { comprometimento no cliente. Os gerentes } \\
\text { acreditam que o contato presencial poderia } \\
\text { gerar mais comprometimento. }\end{array}$ & $\begin{array}{l}\text { Fazer reuniões de resultados presenciais; falar } \\
\text { pelo menos uma vez por mês com todos os } \\
\text { clientes; convidar para eventos; alinhar qual } \\
\text { meu papel na parceria e qual o papel dele. }\end{array}$ \\
\hline Confiança & $\begin{array}{l}\text { Mais uma vez, o volume de clientes } \\
\text { atendidos e a distância física imposta pelo } \\
\text { modelo, dificultam ações facilitem a } \\
\text { construção de uma relação de confiança } \\
\text { gerente de relacionamento-cliente. }\end{array}$ & $\begin{array}{l}\text { Estar presente, ter contato próximo com o } \\
\text { cliente independente do seu potencial de } \\
\text { crescimento; está disposto a escutá-lo; ter } \\
\text { interações presenciais sempre que possível; } \\
\text { ser um consultor e não um vendedor para o } \\
\text { cliente; ser verdadeiro. }\end{array}$ \\
\hline $\begin{array}{l}\text { Comunicação e } \\
\text { Personalização }\end{array}$ & $\begin{array}{l}\text { Com 100-200 contas por gerente de } \\
\text { relacionamento, a maioria das comunicações } \\
\text { tenha que ser feitas de maneira não } \\
\text { personalizada e não frequente. }\end{array}$ & $\begin{array}{l}\text { Personalizar } 100 \% \text { das mensagens aos clientes } \\
\text { e se comunciar com todos eles; fazer ligações } \\
\text { ou videoconferencias; dar preferência a } \\
\text { reuniões presenciais no momento da } \\
\text { comunicação, já que pode favorecer no } \\
\text { estabelecimento da confiança. }\end{array}$ \\
\hline
\end{tabular}

Fonte: desenvolvido pela autora.

É importante destacar que foram encontradas, durante as entrevistas, duas ações consideradas pelos entrevistados como sendo de grande ajuda na retenção de clientes, mas que não necessariamente são ações de marketing de relacionamento. Os três executivos high touch mencionaram o compartilhamento de dados (em forma de métricas, insights e análises) com 
seus clientes como um fator que ajuda na fidelização, já que podem provar o valor do que está sendo entregue. Já os executivos low touch acreditam que, para quem trabalha com diferentes territórios, entender a cultura de cada país ajuda no relacionamento, na abordagem e na minimização das taxas de churn: "(...) os argentinos anunciam o churn antecipadamente e me dão chances de tentar recuperar. O colombiano não, é sempre de última hora, então sei que com eles eu preciso começar a falar em renovação bem antes da data" [Entrevistado F].

No decorrer das entrevistas, enquanto os depoimentos dos entrevistados low touch eram tomados, observou-se a realidade presente, o atual escopo do projeto e as ações que faziam parte do dia a dia dos entrevistados, mas também o depoimento do Entrevistado D, que estava - naquele momento - conduzindo, junto com a liderança da empresa, um projeto piloto contendo mudanças para o modelo low touch. Essas mudanças, segundo ele, foram "pensadas de acordo com todo o aprendizado que vivemos no decorrer desses anos com o projeto e que vemos que são necessárias para ter sucesso com ele [o modelo low touch] na região" [Entrevistado D].

O sucesso desejado pela empresa é a fidelização do maior número de clientes possível, traduzido pela redução das taxas de churn. As mudanças envolvem, diretamente, a inclusão de ações de marketing de relacionamento, mesmo no atendimento em escala, para atingir esse objetivo. As mudanças foram necessárias devido às altas taxas de churn enfrentadas pelo modelo low touch na América Latina: variando entre 30 e $40 \%$ ao ano.

A figura 11, abaixo, apresenta de forma detalhada um resumo dos aprendizados acumulados ao longo do projeto low touch na empresa $A B C$ Software e sua clara correlação com os elementos do marketing de relacionamento abordados no roteiro de entrevista. Os entrevistados E e F relatam as ações que estavam sendo praticadas pela empresa no momento das entrevistas; o entrevistado D, que estava envolvido em um processo de mudança do modelo em busca de melhorias, apresenta o que estava sendo pensado para aperfeiçoá-lo.

Com exceção do elemento qualidade, todos os outros elementos do marketing de relacionamento estudados nesta pesquisa (satisfação, comprometimento, confiança, 
comunicação e personalização), aparecem como protagonistas nas mudanças que estão sendo pensadas para atingir o objetivo inicial do projeto low touch na $A B C$ Software: aumentar a fidelização de clientes, o que se traduzirá pela melhora das taxas de churn no segmento $S M B$ (pequenos e médios negócios).

A ausência do elemento qualidade pode ser explicada pelo fato da sua proximidade, já abordada nesta pesquisa, com o elemento satisfação. Para Barreto (2015), a qualidade tem grande importância na formação da satisfação e efeito direto sobre a fidelidade. É evidente a similaridade entre os dois elementos a tal ponto, que, na figura abaixo, o termo "satisfação" pode ser substituído por "qualidade" sem grande perda de sentido no texto. 


\section{Figura 11 - Aprendizados do projeto Low Touch e o marketing de relacionamento}

\begin{tabular}{|c|c|c|c|}
\hline Satisfação & $\begin{array}{l}\text { Não se mede satisfação. Somente quando } \\
\text { o cliente não renova o contrato é que } \\
\text { sabemos se está satisfeito ou não. Como } \\
\text { posso satisfazer um cliente que não } \\
\text { conheço? }\end{array}$ & $\begin{array}{l}\text { Aprendizado/ } \\
\text { mudança }\end{array}$ & $\begin{array}{l}\text { É possível entender o que é satisfação } \\
\text { para cada cliente mesmo de maneira } \\
\text { escalável. Estabelecer uma meta para } \\
\text { ele no onboarding, enviar um survey } \\
\text { para avaliar satisfação, enviar } \\
\text { brindes, convidar para eventos e } \\
\text { coffee breaks no escritório. }\end{array}$ \\
\hline $\begin{array}{l}\text { Comprometi- } \\
\text { mento }\end{array}$ & $\begin{array}{l}\text { Nós mandamos muitos emails no } \\
\text { onboarding e eles nem abrem os emails } \\
\text { porque não estão comprometidos desde } \\
\text { o início. Eu não faço ações para gerar } \\
\text { comprometimento, porque o volume de } \\
\text { clientes é muito alto. }\end{array}$ & $\begin{array}{l}\text { Aprendizado/ } \\
\text { mudança }\end{array}$ & $\begin{array}{l}\text { Não é o número de toques massivos no } \\
\text { cliente que gera comprometimento, e sim } \\
\text { colocar o sucesso dele nas mãos dele. É } \\
\text { o cliente que agenda a primeira } \\
\text { videoconferência, é o cliente que traça } \\
\text { sua meta e compromisso no onboarding. }\end{array}$ \\
\hline Confiança & $\begin{array}{l}\text { Existem dois fatores que impedem a } \\
\text { formação de confiança com o cliente: o } \\
\text { volume de clientes atendidos e a } \\
\text { distância. } \mathrm{Na} \text { América Latina, é difícil } \\
\text { construir relacionamentos sólidos } \\
\text { apenas de maneira online. }\end{array}$ & $\begin{array}{l}\text { Aprendizado/ } \\
\text { mudança }\end{array}$ & $\begin{array}{l}\text { Queremos blindar o relacionamento, } \\
\text { entendendo o que é valor para o cliente, } \\
\text { qual a necessidade, as dores. Porque eu } \\
\text { preciso que o cliente confie em mim no } \\
\text { sentido de que eu quero ajudá-lo a } \\
\text { alcançar algo, mesmo a distância, mesmo } \\
\text { sem estar ao lado dele fisicamente. }\end{array}$ \\
\hline $\begin{array}{l}\text { Comunicação e } \\
\text { personalização }\end{array}$ & $\begin{array}{l}\text { A comunicação é feita quase sempre de } \\
\text { maneira "massiva" e não } \\
\text { personalizada, devido ao grande } \\
\text { número de clientes. }\end{array}$ & $\begin{array}{l}\text { Aprendizado/ } \\
\text { mudança }\end{array}$ & $\begin{array}{l}\text { A comunicação tem que ser mais } \\
\text { frequente e personalizada no início do } \\
\text { projeto. Isso ajuda a evitar o churn lá na } \\
\text { frente. Ter as dores do cliente no } \\
\text { onboarding, te ajudam a te guiar durante } \\
\text { o ano todo. }\end{array}$ \\
\hline
\end{tabular}

Fonte: desenvolvido pela autora.

Cabe destacar que, apesar do aprendizado de que ações de marketing de relacionamento seriam necessárias para minimizar as taxas de churn, e mesmo diante do fato de que são essenciais até mesmo em modelos de relacionamento escaláveis e no relacionamento com clientes de pequeno porte, a empresa não pretende aplicá-las durante toda a vida útil do cliente. Como o volume de clientes atendidos por gerente de relacionamento é muito alto, fica impossível dar atenção individualizada no decorrer de todo o contrato: "(...) depois de um tempo, a ideia é trabalhar em escola mesmo, já não existe o personalizado, até porque não dá mais, o volume é muito grande" [Entrevistado D]. 
O momento do onboarding do cliente e os noventa dias subsequentes a ele representam o período em que a $A B C$ Software pretende investir em ações de marketing de relacionamento. Esse fato faz muito sentido, uma vez que a literatura discutida nesta pesquisa, na seção 2.2.2, mostra que o onboarding mal-executado é um dos grandes causadores de churn (Payne, 2016; Skok, 2016; Markidan, 2015; Sjoberg \& Winback, 2017).

É ao onboarding que a empresa estudada pretende dedicar um tempo maior para falar de maneira individualizada com cada cliente: entender suas dores, entender o que ele busca na parceria e que seria traduzido, no futuro, em satisfação; traçar suas primeiras metas com o uso da ferramenta, para que um compromisso seja formado, visando estabelecer uma relação de confiança. A literatura de SaaS chama esse onboarding, quando é conduzido de maneira personalizada por um gerente de relacionamento, de onboarding high touch.

A figura a seguir exemplifica bem como a $A B C$ Software pretende seguir engajando seus clientes: primeiro, com um onboarding high touch, e, logo depois, com um seguimento low touch, já que o número de clientes impossibilita uma atenção individualizada a todas as contas.

Figura 12 - Modelos de onboarding

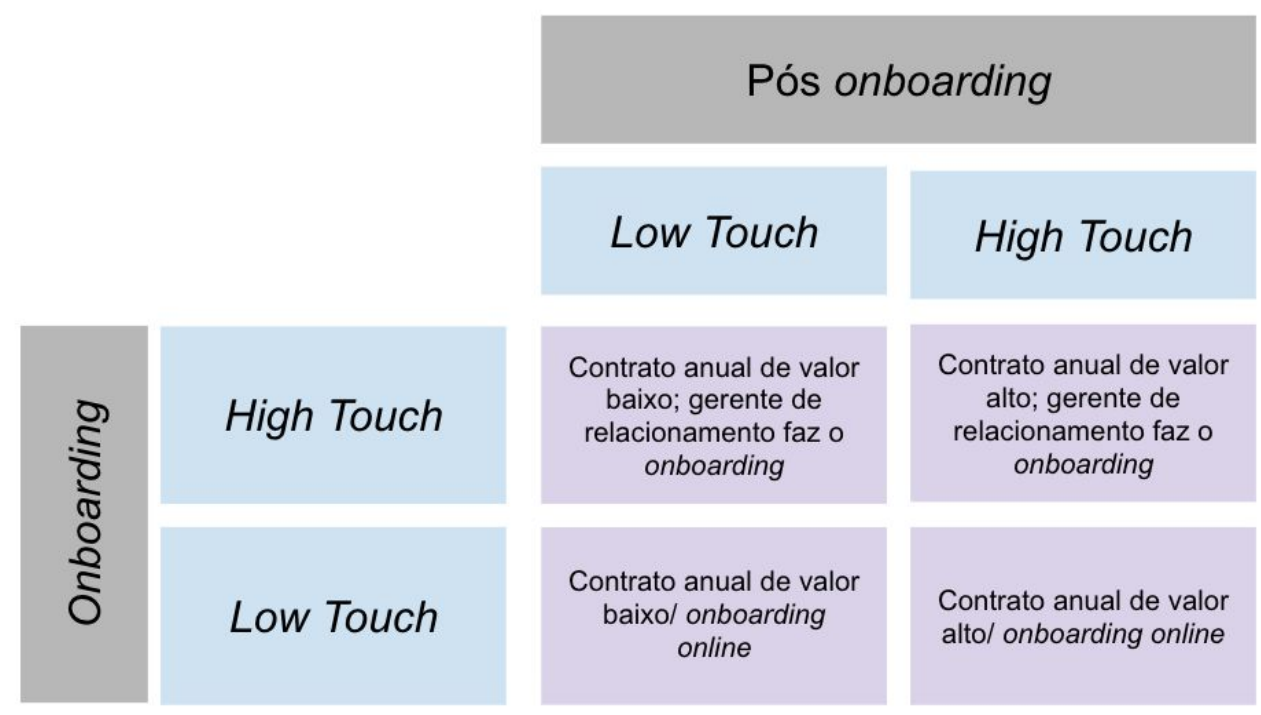

Fonte: adaptado de Alder (2016). 
Alder (2016) sugere o onboarding high touch e o seguimento low touch para empresas que têm produtos complexos e que precisam de configurações avançadas, mas que, depois da venda, possam ser gerenciados digitalmente e em escala, por serem contas de baixa manutenção. O autor sugere o onboarding low touch e o seguimento low touch para empresas que têm um produto intuitivo, fácil de usar e de custo bastante baixo.

Acredita-se que, com o onboarding high touch e o seguimento low touch, a empresa estudada está no caminho certo, já que o $S a a S$ oferecido não é intuitivo, gera muitas dúvidas de utilização nos clientes e tem um contrato anual alto. Essa mudança, de onboarding low touch para onboarding high touch, com a inclusão das ações de marketing de relacionamento que estão sendo propostas, pode levar a empresa a atingir melhores taxas de retenção de clientes.

Por fim, com o depoimento da Entrevistada G, diretora de $S M B$ para a América Latina, foi possível entender de maneira mais ampla o que está sendo proposto pela liderança do projeto low touch para minimizar as taxas de churn do modelo, bem como o papel do marketing de relacionamento na formatação desse novo plano de ação.

Foi perguntado à Entrevistada G o que estava sendo mudado no projeto low touch para garantir a diminuição das taxas de churn no modelo, que, dependendo do país da América Latina, chegava a $40 \%$ ao ano. Mesmo sem nunca ter ouvido falar no termo "marketing de relacionamento", fica evidente, através do seu depoimento, que todas as ações propostas, oriundas de dois anos de aprendizado, são ações desse tipo de marketing.

A Tabela 6, abaixo, foi criada com trechos de seu depoimento falando sobre o novo planejamento a ser seguido em breve por todos os gerentes de relacionamento low touch (na empresa, esse novo modelo está sendo chamado de "novo low touch"). É possível, para cada trecho, fazer uma correlação com os elementos do marketing de relacionamento - o que é colocado pela teoria e seus principais autores. Todos os trechos do depoimento da entrevistada são provenientes de apenas uma pergunta e foram dados nessa mesma ordem. Não foram, contudo, encontradas palavras referentes ao elemento confiança. 
Tabela 6 - O novo Low Touch e o marketing de relacionamento

\begin{tabular}{|c|c|c|c|}
\hline $\begin{array}{c}\text { Depoimento [Entrevistada } G \text { ], } \\
\text { gerente de } S M B \text { LATAM }\end{array}$ & $\begin{array}{c}\text { Elemento do } \\
\text { marketing de } \\
\text { relacionamento }\end{array}$ & Teoria & Autores \\
\hline $\begin{array}{l}\text { A gente quer um processo desenhado para } \\
\text { entregar de forma organizada, planejada e } \\
\text { orquestrada a melhor experiência possível para } \\
\text { esse cliente, para que ele cresça sim, para que } \\
\text { ele consiga expandir sim. }\end{array}$ & Qualidade & $\begin{array}{l}\text { Oferecer serviço de alta } \\
\text { qualidade; Superar a } \\
\text { expectativa dos clientes } \\
\text { quanto a qualidade do } \\
\text { serviço prestado. }\end{array}$ & $\begin{array}{l}\text { Parasuraman, } \\
\text { Zeithan, Berry } \\
\text { (1998); Saliby } \\
\text { (1997) }\end{array}$ \\
\hline $\begin{array}{l}\text { Os clientes têm uma jornada clara do que que } \\
\text { eles vão receber: do marco zero até o terceiro } \\
\text { mês. E isso, consequentemente nos meses } \\
\text { seguintes: treinamentos, eventos, emails, } \\
\text { webinars, etc. Eles também vão receber QBR's } \\
\text { personalizados trimestralmente. }\end{array}$ & $\begin{array}{l}\text { Comunicação e } \\
\text { Personalização }\end{array}$ & $\begin{array}{c}\text { Comunicação deve ser feita } \\
\text { de forma contínua ao longo } \\
\text { de toda relação; Criar uma } \\
\text { estratégia de comunicação } \\
\text { com o cliente e definir que } \\
\text { canais de comunicação serão } \\
\text { usados. } \\
\end{array}$ & $\begin{array}{l}\text { Barreto (2007) } \\
\text { Ndubisi (2005) }\end{array}$ \\
\hline $\begin{array}{l}\text { O cliente recebe um goal setting, faz um } \\
\text { planejamento. Tem um onboarding de trinta } \\
\text { dias, responde a surveys. }\end{array}$ & Comprometimento & $\begin{array}{c}\text { As empresas que oferecem } \\
\text { benefícios superiores aos } \\
\text { seus clientes serão altamente } \\
\text { valorizadas e os clientes se } \\
\text { comprometerão a estabelecer, } \\
\text { desenvolver e manter } \\
\text { relacionamentos com esses } \\
\text { parceiros. }\end{array}$ & $\begin{array}{l}\text { Morgan \& Hunt } \\
\text { (1994); Sweeney } \\
\text { \& Webb (2007) }\end{array}$ \\
\hline $\begin{array}{l}\text { A gente coloca a partir de agora uma nota de } \\
\text { satisfação em relação ao que é entregue. A } \\
\text { gente está buscando uma meta de fazer com que } \\
\text { o maior número possível de clientes novos que } \\
\text { passa por onboarding dê pelo menos uma nota } \\
\text { de oito, NPS mesmo, após } 30 \text { dias de contrato. } \\
\text { É uma nota mínima em relação a satisfação do } \\
\text { que foi entregue pelo serviço, ou seja, pelo } \\
\text { atendimento do gerente de relacionamento, e } \\
\text { também satisfação em relação ao produto. }\end{array}$ & Satisfação & $\begin{array}{l}\text { Existem diferentes maneiras } \\
\text { de medir satisfação. Uma } \\
\text { delas é fazer um survey ou } \\
\text { questionário de satisfação } \\
\text { entre a base de clientes; A } \\
\text { satisfação do cliente cria um } \\
\text { forte relacionamento } \\
\text { provedor-cliente, o que } \\
\text { resulta em um } \\
\text { relacionamento duradouro. }\end{array}$ & $\begin{array}{l}\text { Gronroos (1994) } \\
\text { Gronroos (1990) }\end{array}$ \\
\hline
\end{tabular}

Fonte: desenvolvido pela autora.

O foco da Entrevistada G nas ações descritas acima, além de reduzir as taxas de churn da sua equipe em $10 \%$ até o final de 2020 , está em provar que o modelo de atendimento low touch e o modelo high touch têm apenas uma diferença: o contato presencial com os clientes. 


\section{Considerações finais}

O marketing de relacionamento, citado pela primeira vez na década de 1980, teve seu início muito antes do surgimento da primeira empresa provedora de SaaS B2B do mundo. Embora não tenha sido idealizado para fidelizar clientes nesse setor, suas práticas e ações recomendadas podem, até hoje, guiar essas empresas rumo ao seu maior desafio: a fidelização de clientes.

$\mathrm{Na}$ primeira parte desta pesquisa, o referencial teórico focou-se em fazer uma correlação entre o setor de SaaS e o marketing de relacionamento, para garantir que existia sinergia entre o problema (retenção de clientes em $\operatorname{Sa} S$ B2B) e a possível solução (marketing de relacionamento). Foram listadas as principais causas de churn em empresas SaaS B2B encontradas na literatura, bem como as ações que a teoria do marketing de relacionamento e seus autores sugerem, de maneira prática, para atingir o objetivo de reter clientes. Nesse contexto, os seguintes elementos do marketing de relacionamento se sobressaíram no combate ao churn em SaaS: satisfação, qualidade, comunicação e personalização (Tabela 2, p.51).

$\mathrm{Na}$ fase seguinte do trabalho, o estudo de caso, foi possível perceber que, enquanto os gerentes de relacionamento high touch listaram vários exemplos de ações de marketing de relacionamento que ajudam na retenção de clientes (garantindo satisfação, estabelecendo confiança, personalizando a comunicação, entre outros), os gerentes de relacionamento low touch indicam o alto volume de clientes (100 a 200 clientes por gerente de relacionamento) e a distância imposta pelo modelo (não poder visitar seus clientes presencialmente) como as duas principais razões que impedem que eles ajam em prol da retenção de seus clientes. A falta dessas ações fez com que as taxas de churn do projeto low touch na América Latina chegassem a $30-40 \%$ ao ano.

$\mathrm{Na}$ tentativa de conter as taxas de churn, várias mudanças, oriundas do aprendizado da empresa nos últimos dois anos de projeto, começaram a ser desenhadas e colocadas em prática por meio de um projeto piloto. No momento da condução das entrevistas, um novo 
onboarding estava sendo desenhado para concentrar as ações de marketing de relacionamento que deveriam ser praticadas por todos os gerentes de relacionamento low touch no futuro.

Dessa forma, esta pesquisa foi bem-sucedida, uma vez que elucidou a importância de ações de marketing de relacionamento em interações com clientes $B 2 B$ de $S a a S$, mesmo em um projeto que se propunha ir na contramão do que prega a teoria do marketing de relacionamento. Ficou evidente que ações que busquem satisfação, qualidade, comprometimento, confiança, assim como comunicação constante e de maneira personalizada, podem e devem ser aplicadas não somente em grandes empresas e de maneira individual, mas também em escala, ao atender clientes pequenos.

É importante ressaltar que esta pesquisa teve como limitação o fato de se tratar de um estudo de caso único, com o objetivo específico de se aprofundar nos modelos de relacionamento de uma única empresa. Portanto, seus achados não podem ser generalizados. Apesar disso, acredita-se que os aprendizados sirvam para empresas com características similares, principalmente comercializadores de software $B 2 B$.

Como sugestões para trabalhos futuros, indica-se o estudo do relacionamento $B 2 B$ no setor de SaaS na perspectiva do cliente assinante, identificando até que ponto as ações de marketing de relacionamento praticadas pela empresa são decisivas no momento de renovar ou não seu contrato. 


\section{Referências}

Alder, B. (2016), 4 engagement models for customer success. Recuperado de $<$ https://www.clientsuccess.com/blog/4-engagement-models-for-customer-success/>. Acesso em 15/04/2020.

Andersen, P. H. (2001). Relationship development and marketing communication: an integrative model. Journal of Business \& Industrial Marketing.

Armbrust, M., Fox, A., Griffith, R., Joseph, A. D., Katz, R., Konwinski, A., ... \& Zaharia, M. (2010). A view of cloud computing. Communications of the ACM, 53(4), 50-58.

Balieiro, F. (2019). Churn Rate: sinal de alerta para perda de clientes. Recuperado de: $<$ https://www.agendor.com.br/blog/churn-rate/>. Acesso em 29/12/2019.

Bardin, L., (1977). Análise de conteúdo. Lisboa: edições, 70.

Barreto, I. F., (2007). Avaliação de resultados de ações de marketing de relacionamento. (Dissertação (Mestrado em Administração), Faculdade de Economia, Administração e Contabilidade, Universidade de São Paulo. Recuperado de: https://www.teses.usp.br/teses/disponiveis/12/12139/tde-17102007-163419/pt-br.php

Barreto, I. F., (2015). Resultados de marketing de relacionamento: propósição de modelo por meio de mapeamento cognitivo. (Tese de doutorado, Faculdade de Economia, Administração e Contabilidade Universidade de São Paulo). Recuperado de: https://teses.usp.br/teses/disponiveis/12/12139/tde-01102015-152612/pt-br.php

Bejou, D., Ennew, C.T. and Palmer, A. (1998), Trust, ethics and relationship satisfaction, International Journal of Bank Marketing, Vol. 16 No. 4, pp. 170-175.

Benlian, A., Koufaris, M., \& Hess, T. (2010). The Role of SaaS Service Quality for Continued SaaS Use: Empirical Insights from SaaS Using Firms. In ICIS.

Berry, L. L. (1995). Relationship marketing of services-growing interest, emerging perspectives. Journal of the Academy of marketing science, 23(4), 236-245.

Berry, L.M. Relationship Marketing (1983). Emerging Perspectives on Services Marketing, American Marketing Association, Chicago, Proceedings Series, pp. 25-8, 1983.

Berry, L. L., Zeithaml, V. A., \& Parasuraman, A. (1996). The behavioral consequences of service quality. Journal of marketing, 60(2), 31-46.

Berry, L. L., \& Parasuraman, A. (1991). Marketing services: Competing through quality. Simon and Schuster. 
Blog Microsoft Azure (2019). O que é SaaS. Recuperado de: $<$ https://azure.microsoft.com/pt-br/overview/what-is-saas> Acesso em: 19/05/2019.

Bonfiglio, N., \& Alon, M. (2017). Mastering Product Experience (in SaaS): How to Deliver Personalized Product Experiences with a Product-led Strategy.

Brodie, R. J., Coviello, N. E., Brookes, R. W., \& Little, V. (1997). Towards a paradigm shift in marketing? An examination of current marketing practices. Journal of marketing management, 13(5), 383-406.

Brown, C. W., \& Nyarko, K. (2013). Software as a service (SaaS). In Cloud Computing Service and Deployment Models: Layers and Management (pp. 50-69). IGI Global.

Cardoso, M. (2017, May). The onboarding effect: Leveraging user engagement and retention in crowdsourcing platforms. In Proceedings of the 2017 CHI Conference Extended Abstracts on Human Factors in Computing Systems (pp. 263-267).

Christopher, M., Payne, A., \& Ballantyne, D. (1991). Relationship marketing: bringing quality customer service and marketing together.

Chong, F., Carraro, G., \& Wolter, R. (2006). Multi-tenant data architecture. MSDN Library, Microsoft Corporation, 14-30.

Crosby, L.A., Evans, K.R. and Cowles, D. (1990), Relationship quality in services selling: an interpersonal influence perspective, Journal of Marketing, Vol. 54 July, pp. 68-81.

Crosby, L.A. and Stevens, N. (1987), Effects of relationship marketing on relationship satisfaction, retention and prices in the life insurance industry, Journal of Marketing Research, Vol. 24, November, pp. 404-11

Czepiel, J. A. (1990). Managing relationships with customers: A differentiating philosophy of marketing (pp. 299-323). San Francisco: Jossey-Bass.

Day, G. S. (1997). Maintaining the competitive edge: creating and sustaining advantages in dynamic competitive environments. Wharton on dynamic competitive strategy, 48-75.

Duncan, T., \& Moriarty, S. E. (1998). A communication-based marketing model for managing relationships. Journal of marketing, 62(2), 1-13.

Eriksson, J. (2013). Building the Sales Process: Case: Intunex Ltd.

GARTNER GROUP. Gartner Forecasts Worldwide Public Cloud Revenue to Grow 17.5 Percent in 2019, 2019. Recuperado de: $<$ https://www.gartner.com/en/newsroom/press-releases/2019-04-02-gartner-forecasts -worldwide>. Acesso em: 10/04/2019. 
Ge, Yizhe., He, S., Xiong, J., \& Brown, D. E. (2017, April). Customer Churn Analysis for a Software-as-a-service Company. In 2017 Systems and Information Engineering Design Symposium (SIEDS) (pp. 106-111). IEEE.

Gentilini, C. (2018), How SaaS Startups Can Build Lasting Customer Relationships. Recuperado de: $<$ https://how-saas-startups-can-build-lasting-customer-relationships-69e97f1 da5b3 $>$. Acesso em 01/06/2019.

Geyskens, Inge , Jan-Benedict E. M. Steenkamp , Lisa K. Scheer, and Nirmalya Kumar (1996), The Effects of Trust and Interdependence on Relationship Commitment: A Trans-Atlantic Study, International Journal of Research in Marketing, 13 (October), 303-317.

Gil, A. C. (2002). Como classificar as pesquisas. Como elaborar projetos de pesquisa, 4, 44-45.

Gil, A. C. (2008). Métodos e técnicas de pesquisa social. 6. ed. Editora Atlas SA.

Godoy, A. S. (1995). A pesquisa qualitativa e sua utilização em administração de empresas. Rev. adm. empres, 65-71.

Gordon, M. E., McKeage, K., \& Fox, M. A. (1998). Relationship marketing effectiveness: the role of involvement. Psychology \& Marketing, 15(5), 443-459.

Gronroos, C. (1990). Relationship approach to marketing in service contexts: The marketing and organizational behavior interface. Journal of business research, 20(1), 3-11.

Grönroos, C., Storbacka, K., \& Strandvik, T. (1994). Managing customer relationships for profit: the dynamics of relationship quality. International journal of service industry management.

Grönroos, C. (1996). Relationship marketing: strategic and tactical implications. Management decision.

Gruen, T. W., Summers, J. O., \& Acito, F. (2000). Relationship marketing activities, commitment, and membership behaviors in professional associations. Journal of marketing, 64(3), 34-49.

Gummesson, E. (2000). Qualitative methods in management research. Sage.

Gummesson, E. (1997). Relationship marketing as a paradigm shift: some conclusions from the 30R approach. Management decision.

Hair, J., Babin, B., Money, A., \& Samouel, P. (2005). Fundamentos de métodos de pesquisa em administração. Bookman Companhia Ed. 
Hausman, A., Noori, B., \& Salimi, M. H. (2005). A decision-support system for business-to-business marketing. Journal of Business \& Industrial Marketing.

Hennig-Thurau, T., Gwinner, K. P., \& Gremler, D. D. (2002). Understanding relationship marketing outcomes: an integration of relational benefits and relationship quality. Journal of service research, 4(3), 230-247.

Hennig-Thurau, T., \& Klee, A. (1997). The impact of customer satisfaction and relationship quality on customer retention: A critical reassessment and model development. Psychology \& marketing, 14(8), 737-764.

Iacobucci, D., \& Ostrom, A. (1996). Commercial and interpersonal relationships; using the structure of interpersonal relationships to understand individual-to-individual, individual-to-firm, and firm-to-firm relationships in commerce. International Journal of Research in Marketing, 13(1), 53-72.

Jussila, J. J., Kärkkäinen, H., \& Aramo-Immonen, H. (2014). Social media utilization in business-to-business relationships of technology industry firms. Computers in Human Behavior, 30, 606-613.

KeyBanc Capital Markets (2018). SaaS Survey Results (Relatório de gestão de empresas privadas de SaaS).

Kienitz, P. (2018), Why SaaS is growing faster than ever. Recuperado de $<$ https://www.dcslsoftware.com/saas-growing-faster-ever/ $>$ Acessado em 10.04.2020.

Khan, M. T. (2014). Relationship marketing-some aspects. International Journal of Information, Business and Management, 6(2), 108.

Law, R. (2019). How high is too high: a meta analysis of churn studies. Recuperado de: $<$ https://www.cobloom.com/blog/churn-rate-how-high-is-too-high\#>. Acesso em $01 / 05 / 2020$.

Le, T. (2019). Growth Hacking and AAARR Funnel Implementation for a SaaS company.

Lengnick-Hall, C. A. (1996). Customer contributions to quality: A different view of the customer-oriented firm. Academy of management review, 21(3), 791-824.

Lipset, S. M., Trow, M. A., \& Coleman, J. S. (1956). Union democracy: The internal politics of the International Typographical Union (Vol. 296). Free Press.

Leonidou, L. C. (2004). Industrial manufacturer-customer relationships: The discriminating role of the buying situation. Industrial Marketing Management, 33(8), 731-742. 
Luoma, E. (2013). Examining business models of software-as-a-service firms. In International conference on grid economics and business models (pp. 1-15). Springer, Cham.

Markidan, L., Why Customer Churn happens and what you can do about it. Recuperado de: $<$ https://www.groovehq.com/blog/reduce-customer-churn>. Acesso em 29.03/2020.

Mattar, F. N. (1999). Pesquisa de marketing (Vol. 6). São Paulo: Atlas.

Maxim, A. (2009). Relationship marketing-A new paradigm in marketing theory and practice. Analele Stiintifice ale Universitatii" Alexandru Ioan Cuza" din Iasi-Stiinte Economice, 56, 287-300.

Mehta, N., Steinman, D., \& Murphy, L. (2016). Customer success: how innovative companies are reducing churn and growing recurring revenue. John Wiley \& Sons.

Miguéis, V. L., Van den Poel, D., Camanho, A. S., \& e Cunha, J. F. (2012). Modeling partial customer churn: On the value of first product-category purchase sequences. Expert systems with applications, 39(12), 11250-11256.

Moraes, R. (1999). Análise de conteúdo. Revista Educação, Porto Alegre, 22(37), 7-32.

Morgan, R. M., \& Hunt, S. D. (1994). The commitment-trust theory of relationship marketing. Journal of Marketing, 58(3), 20-38

Murphy, L. (2017). Churn rate tudo o que você precisa saber. Recuperado de em<https://blog.superlogica.com/assinaturas/churn/>. Acesso em 19/03/2020.

Murphy, L. (2018). Customer Success: the definitive guide 2019. Recuperado de: $<$ https://sixteenventures.com/customer-success-definition>. Acesso em 25/03/2020.

Murphy, L., Mehta, N., \& Steinman, D. (2016). Customer success: how innovative companies are reducing churn and growing recurring revenue. John Wiley \& Sons.

Mutanen, T. (2006). Customer churn analysis-a case study. Journal of Product and Brand Management, 14(1), 4-13.

Najjar, A., Boissier, O., \& Picard, G. (2017, May). Aquaman: an adaptive qoe-aware negotiation mechanism for saas elasticity management. In Proceedings of the 16th Conference on Autonomous Agents and MultiAgent Systems (pp. 1655-1657).

Ndubisi, N. O. (2007). Relationship marketing and customer loyalty. Marketing intelligence \& planning.

Ndubisi, N. O., \& Wah, C. K. (2005). Factorial and discriminant analyses of the underpinnings of relationship marketing and customer satisfaction. International journal of bank marketing. 
Oliver, Richard L. (1980), A Cognitive Model of the Antecedents and Consequences of Satisfaction Decisions. Journal of Marketing Research, 17 (November), 460-69.

Palmatier, R. W., \& Steinhoff, L. (2019). Relationship marketing in the digital age. Routledge.

Palmatier, R. W., Zhang, J. Z., Watson Iv, G. F., \& Dant, R. P. (2016). Dynamic relationship marketing. Journal of Marketing, 80(5), 53-75.

Parasuraman, A., Zeithaml, V. A., \& Berry, L. L. (1988). Servqual: A multiple-item scale for measuring consumer perc. Journal of retailing, 64(1), 12.

Payne, J., (2016). Reducing SaaS churn checklist. Recuperado de: < https://blog.incisive-edge.com/blog/reducing-saas-churn-checklist>. Acesso em 10.04.2020.

Pride, W. (2001). Ferrell OC Marketing: conceitos e estratégias. Rio de Janeiro: Editora LTC.

Pritchard, M. P., Havitz, M. E., \& Howard, D. R. (1999). Analyzing the commitment-loyalty link in service contexts. Journal of the academy of marketing science, 27(3), 333

Rai, A., SaaS Churn. (Part 1 of 3): Why Churn Happens \& What You Can Do About It (2018).

Recuperado

de:

$<$ https://productcoalition.com/saas-churn-part-1-of-3-why-churn-happens-what-youcan-do-about-it-37179e39e332>. Acesso em 10.04.2020.

Rautio, A. (2019). Churn prediction in SaaS using machine learning.

Reichheld, F.E. and Sasser, W.E. Jr (1990), Jr Zero defections: Quality comes to service, Harvard Business Review. Recuperado de: $<$ https://hbr.org/1990/09/zero-defections-quality-comes-to-services $>$ Acessado em 10.04.2020.

Rocha, A. D., \& Luce, F. B. (2006). Relacionamentos entre compradores e vendedores: origens e perspectivas no marketing de relacionamento. Revista de Administração de Empresas, 46(3), 87-93.

Samaha, S. A., Beck, J. T., \& Palmatier, R. W. (2014). The role of culture in international relationship marketing. Journal of Marketing, 78(5), 78-98.

Saliby, P. E. (1997). O marketing de relacionamento: o novo marketing da nova era competitiva. RAE-Revista de Administração de Empresas, 6-12.

Salomann, H., Dous, M., Kolbe, L., \& Brenner, W. (2007). Self-service Revisited:: How to Balance High-tech and High-touch in Customer Relationships. European Management Journal, 25(4), 310-319. 
Selltiz, C., Wrightsman, L. S., \& Cook, S. W. (1976). Research methods in social relations. Holt, Rinehart and Winston.

Seybold, P. B. (2002). The Five Waves of Customer Relationship Management-How CRM Functionality and Architecture Have Evolved. Business Briefing: Data Management \& Storage Technology, 1-2.

Sjöberg, J., \& Winbäck, H. (2017). Designing the user onboarding process in analytics software Taking an omnichannel perspective (Master's thesis).

Skok, D. (2016, dezembro). Top two reasons for churn. For entrepreneurs.com. Recuperdo de: <https://www.forentrepreneurs.com/top-two-reasons-for-churn> Acesso em: $01 / 06 / 2019$.

Skok, D. (2016). SaaS metrics 2.0-a guide to measuring and improving what matters. For entrepreneurs.com. Recuperado de: $<$ https://www.forentrepreneurs.com/pt-br/saas-metrics-2/>. Acesso em: 03/03/2019.

Solomon, J. (2019) Why is a customer more than a King in SaaS? Chargebee.com. Recuperado de: <https://www.chargebee.com/blog/customer-king-saas/>. Acesso em: 01/06/2019.

Song, J., Yang, Z., Yang, L., Gong, K., Pan, C., Wang, J., \& Wu, Y. (2007). Technical review on Chinese digital terrestrial television broadcasting standard and measurements on some working modes. IEEE Transactions on Broadcasting, 53(1), 1-7.

Suthar, S. (2019) 12 SaaS customer support best practice to deliver perfect customer support. Acquire.io, . Recuperado de: $<$ https://acquire.io/blog/saas-customer-support-best-practices/>. Acesso em: 23/09/2019.

Tanuri, G. (2016). Vencendo o desafio de aplicar o marketing de relacionamento em uma SaaS. Piz.com. Recuperado de: $<$ https://pipz.com/br/blog/marketing-relacionamento-aumenta-receita-saas/>. Acesso em: 02//04/2019.

Theóphilo, C. R., \& Martins, G. D. A. (2007). Metodologia da investigação científica para ciências sociais aplicadas. São Paulo: Atlas.

Tyrväinen, P., \& Selin, J. (2011). How to sell SaaS: a model for main factors of marketing and selling software-as-a-service. In International Conference of Software Business (pp. 2-16). Springer, Berlin, Heidelberg. 
Ulaga, W., \& Eggert, A. (2006). Relationship value and relationship quality: Broadening the nomological network of business-to-business relationships. European Journal of marketing, 40(3-4), 311-327.

Ventura, M. M. (2007). O estudo de caso como modalidade de pesquisa. Revista SoCERJ, 20(5), 383-386.

Vergara, S. (1997). Metodologia de pesquisa social. São Paulo: Atlas, 44-50.

Vieira, C. S., de Souza Meirelles, F., \& Cunha, M. A. (2015). Fatores que influenciam o indivíduo na utilização da Computação em Nuvem. In CONF-IRM (p. 28).

Woo, K. S., \& Ennew, C. T. (2004). Business-to-business relationship quality. European journal of marketing.

Xie, Y., Li, X., Ngai, E. W. T., \& Ying, W. (2009). Customer churn prediction using improved balanced random forests. Expert Systems with Applications, 36(3), 5445-5449.

Yang, C. C., \& Chou, S. W. (2015). Understanding the Success of Software-as-a-Service (SaaS)-The Perspective of Post-Adoption Use. In PACIS (p. 198).

Yin, R. K. (2015). Estudo de Caso: Planejamento e métodos. Bookman editora. 


\section{ANEXO 01 - ROTEIRO DE PESQUISA}

1 - Como a empresa se relaciona com seus clientes existentes?

2 - Você poderia explicar com mais detalhes as diferenças entre esses dois modelos de atendimento (high touch e low touch)?

3 - Falando de satisfação, o que você faz, dentro do seu modelo de atendimento, para garantir satisfação? Como ela é medida?

4 - Qual a relação percebida por você entre qualidade do serviço prestado e a retenção de clientes? Quais ações você pratica para garantir a qualidade no atendimento aos seus clientes nesse modelo?

5 - Morgan e Hunt (1994), ao apresentar sua teoria comprometimento-confiança, definem o comprometimento como o desejo de continuar o relacionamento com a outra parte. O que você faz para gerar comprometimento no cliente?

6 - Na sua opinião, o que pode ser feito por um prestador de serviço para gerar confiança no seu cliente e garantir retenção?

7 - Como é feita a sua comunicação com o cliente? Você sente que ela é feita de maneira frequente e de duas vias? 